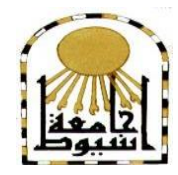

كلية التربية لاطفولة المبكرة

إدارة البموث والنشر العلمي (المبلة العلمية)

$=====$

\title{
فاعلية وحدة مقترحة لتنمية بعض مغاهيم ومهارات المواطنة الرقمية لدى طفل الروضة
}

\author{
إعــــداد \\ د./ هببة أحمد أُممد البنا \\ مدرس تربية الطقل \\ كلية التربية للطفولة المبكرة \\ جامعة المنوفية الطولة
}

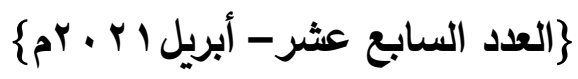




\section{مجلة " دراسات في الطفولة والتربية" - جامعة اسيوط}

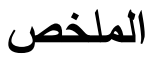

استهدفت هذه الدراسة التعرف على فاعلية وحدة مقترحة لتتمية بعض مفاهيم ومهارات المواطنة الرقمية لدى طفل الروضة، وقد تحددت مشكلة الدراسة في السؤال الرئيس الآتي: "ما فاعلية وحدة مقترحة في تتمية بعض مفاهيم ومهارات المواطنة الرقمية

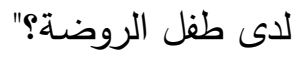

لذا فقد قامت الباحثة بإعداد قائمة بمفاهيم، ومهارات المواطنة الرقمية التي يمكن تتميتها لدى طفل الروضة، والتي في ضوءها تم إعداد تصور لوحدة مقترحة لتنمية بعض مفاهيم ومهارات المواطنة الرقمية لدى طفل الروضة.

كما قامت الباحثة بإعداد اختبار مفاهيم على الوحدة المقترحة، وبطاقة ملاحظة لمهارات المواطنة الرقمية لقياس جوانب التعلم المختلفة لدى طفل الروضة المرتبطة

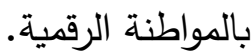

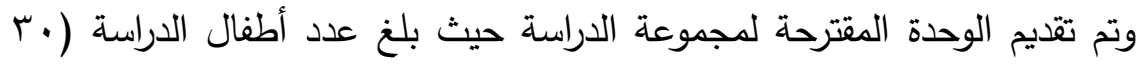

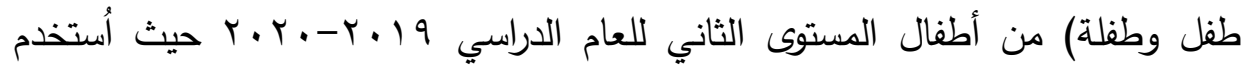
المنهج شبه التجريبي القائم على تصميم المجموعة الواحدة، والقياس القبلي والبعدي. واستخدمت الأساليب الإحصائية المناسبة لاختبار فاعلية الوحدة وفروض الدراسة، ودلت لتهيك نتائج الدراسة على فاعلية الوحدة المقترحة في تنمية بعض مفاهيم ومهارات المواطنة

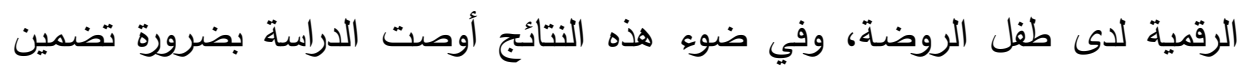
أنشطة في مناهج رياض الأطفال لتتمية مفاهيم ومهارات المواطنة الرقمية لطفل

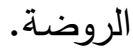

الكلمات المفتاحية

المواطنة الرقمية، طفل الروضة، أنشطة وتطبيقات، الرقمية. 


\section{The Effectiveness of a Suggested Unit to Develop Some Digital Citizenship Concepts and Skills of Kindergarten Child}

\section{Abstract}

This study aimed at identifying the effectiveness of a suggested unit for developing some concepts and skills of digital citizenship of kindergarten child. The study problem is identified in the following main question: "What is the effectiveness of a suggested unit in developing some concepts and skills of digital citizenship of kindergarten child?"

The researcher prepared a list of the concepts and skills of digital citizenship that can be developed in kindergarten child, in the light of which a proposal was prepared for a suggested unit to develop some concepts and skills of digital citizenship of kindergarten child. The researcher also prepared a concept test on the suggested unit, and an observation card for digital citizenship skills to measure the different aspects of learning of the kindergarten child related to digital citizenship. The suggested unit for the study group (30 boys and girls) of the second kindergarten level for the 2019-2020 academic year. The quasi-experimental deign of one group, and pre- and post-testing were used. Appropriate statistical methods were used to test the effectiveness of the unit and the study hypotheses. The results of the study indicated the effectiveness of the suggested unit in developing some concepts and skills of digital citizenship of kindergarten child. In light of these results, the study recommended the need to include activities in the kindergarten curricula to develop the concepts and skills of digital citizenship of kindergarten child.

\section{key words}

Digital citizenship, kindergarten child, activities and applications, digital

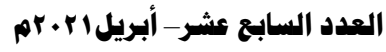




\section{مجلة " دراسات في الطفولة والتربية" - جامعة اسيوط}

مقدمة

إن ما يشهده العالم اليوم من ثورة الاتصالات الرقمية، والمستحدثات التكنولوجية يمثل نقطة فارقة في تاريخ البشرية؛ من خلال قدرتها على تحقيق التواصل اللحظي بين

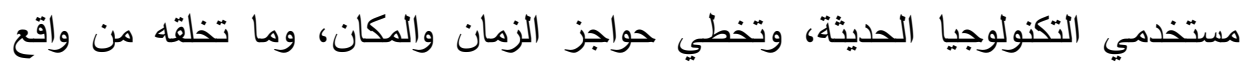
افتراضي في الفضاء الإلكتروني يتميز عن الواقع الفعلي بالتحرر من القيود ،فأصبح العالم قرية صغيرة يتواصل أفرادها ببعضهم البعض من خلال ما تتجها التكنولوجيا

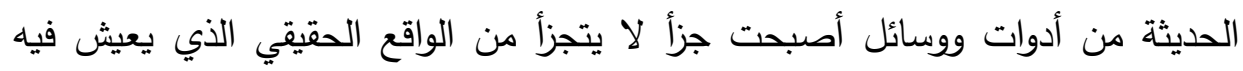

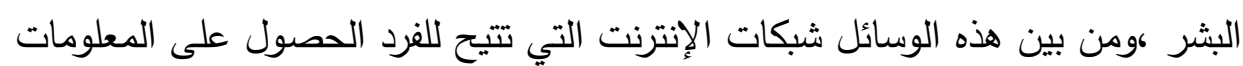

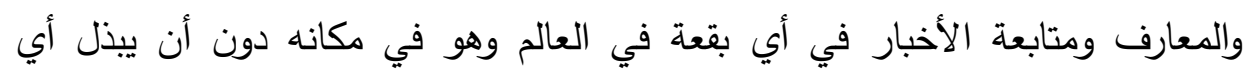
مجهود سوي الضغط على لوحة دفاتيح الحاسب الذي أمامه.

هذا، وقد أفضى التقدم الهائل في تكنولوجيا الاتصالات والمعلومات إلى إنتاج وسائل إلكترونية حديثة في التواصل الاجتماعي ساعدت على إحداث تغيير في علاقات وتفاعلات البشر وتواصلهم مع بعضهم البعض، فمن خلال الإنترنت يستطيع الفرد

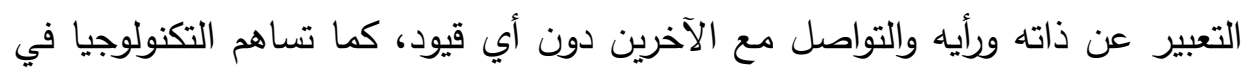
تتمية مهارات التواصل الاجتماعي من خلال نقل الأفكار والتجارب وتبادل الخبر التبرات

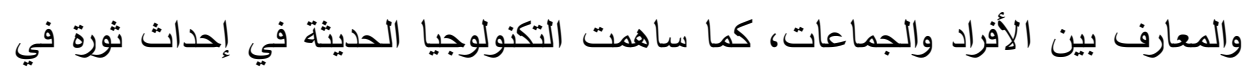

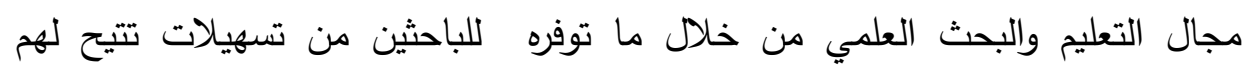

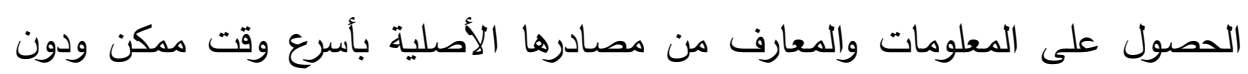
العناء من مشقة السفر والانتقال من مكان لآخر .

وتعد التكنولوجيا سلاح ذو حدين، فمن خلالها يستطيع الإنسان الحصول على المعلومات والمعارف، ومعرفة ما يدور خارج النطاق الذي يعيش فيه مثل متابعة الأخبار

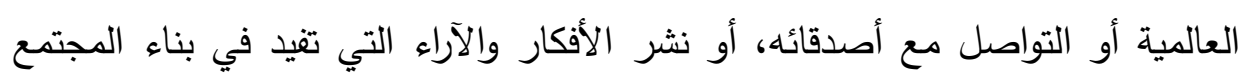
وتحقيق التماسك بين أفراده، وفي نفس الوقت قد يستخدمها الإنسان بثكل غير رشيد فئ التيه

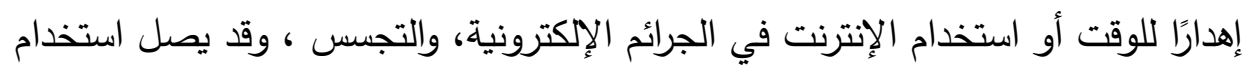


الفرد للتكنولوجيا لدرجة الإدمان وعدم القدرة على التحكم في استخدامها وتقنينها ؛ويترتب

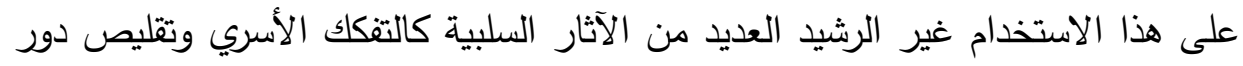

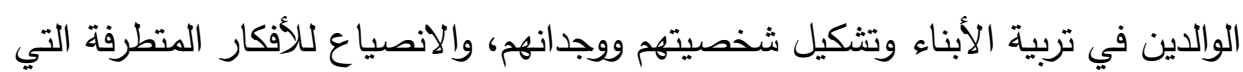

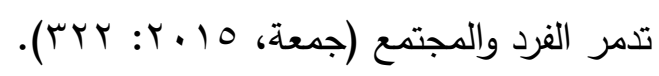

ومع ما وفرته ثورة الاتصالات الرقمية من انتثار الأجهزة اللوحية والكفية، والهواتف الذكية المحمولة واستخدامها في كل وقت ومكان، وتوافر الإنترنت وإتاحته في

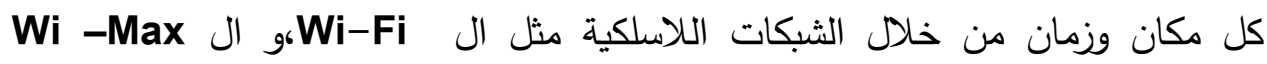
وخدمات الحوسبة السحابية وغيرها ،أصبحت التكنولوجيا تتحدى المعلمين في المدارس، والآباء في المنازل، وذلك من خلال استخدام الشباب والأطفال لهذه التكنولوجيا استخدام

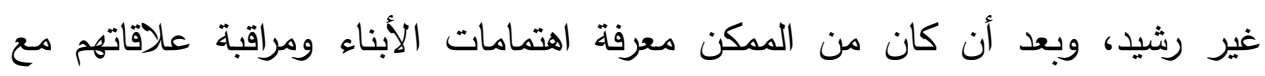
الآخرين ،أصبحوا الآن يتعاملون مع مجهولين رقميين يثكلون خطرًا قويًا على تربية الأبناء وتثكيل شخصياتهم مما يساهم في اختلال منظومة القيم وقواعد السلوك وتنامي العنف وتفكك العلاقات، لذا أصبحنا في حاجة ماسة لإجراءات وقائية ضد ضداء أخطار التكنولوجيا للاستفادة من مميزاتها ،وتفادي عيوبها وذلك من خلال توعية الأبناء مجموعة

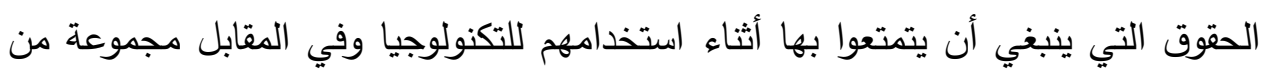

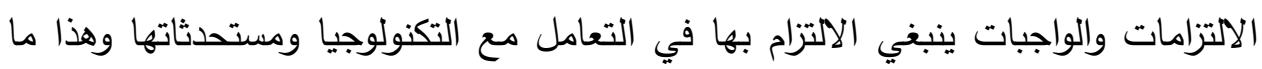

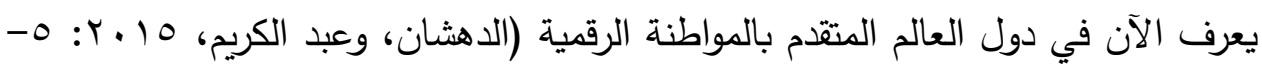

لقد أصبح من الضروري على كل من يحيا في هذا العصر الرقمي (عصر الاتصال وتكنولوجيا المعلومات) أن يكون على وعى ودرئ من يحيا في بواجباته وحقوقه أثناء

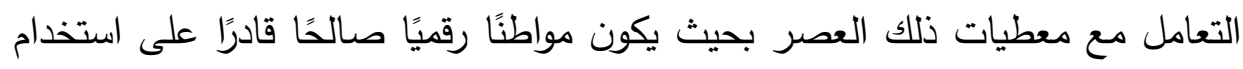

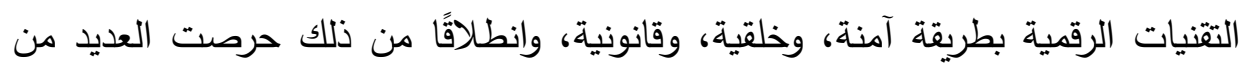

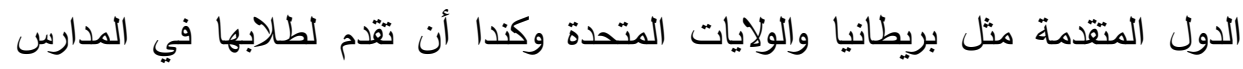
مواضيع خاصة بالمواطنة الرقمية في إطار منهج التربية الرقمية ، كما تبنت استراليا 


\section{مجلة " دراسات في الطفولة والتربية" - جامعة اسيوط}

مشروعًا ينص على تعميم تدريس المواطنة الرقمية للطلاب مع تدريب الآباء والمعلمين عليها وفق خطة وطنية متكاملة.

إن استخدام التكنولوجيا لم يعد قاصرًا على الكبار والثباب فقط ،بل أصبح الأطفال من بين أكثر الفئات تعاملًا مع هذه التكنولوجيا من خلال استخدام الألعاب

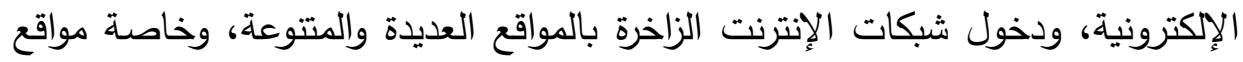
الألعاب التي تعد بمثابة وجبة شيقة يقضي معها الأطفال فترات طويلة دون أن يشعروا

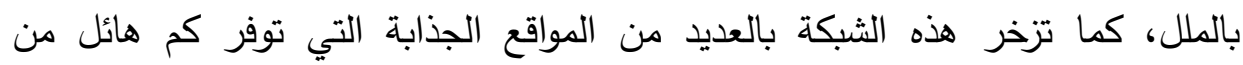
المعلومات حول مختلف جوانب الحياة دون أي موانع متجاوزة الحدود الجغرافية والسياسية والاجتماعية، كما يتيح البريد الإلكتروني لمستخدميه فرصة التواصل مع أي دوني شخص آخر مهما كان موقعه وتبادل الأخبار والمعلومات، وإرسال الخطابات والرسائل ونقل الملفات، كما تسمح بإثراء المعلومات حول شتى المجالات الدينية والاجتماعية

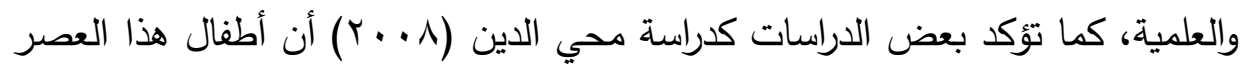
يجيدوا التعامل مع الكمبيوتر والتفاعل مع الإنترنت بدافع الحب الفطري، والسعي الدائم للاستكثاف والإقبال على كل ما هو جديد.

إن استخدام الأطفال للتكنولوجيا وارتيادهم لمواقع الإنترنت يعد بمثابة عملة ذات وجهين إحداهما مضيء يتمثل فيما يقدمه من معلومات تساهم في تعليم وتثقيف الطفل والارتقاء بمهاراته وقدراته، فضلًا عن استخدامه في العملية التعليمية واستخدامه كأداة لتطوير التعليم وإثراء مناهج وبرامج الطفل وإزالة جمود العملية التعليمية، أما الجانب المظلم يتضح فيما تؤكده العديد من الدراسات على الآثار الضارة التي يسبيها استخدام

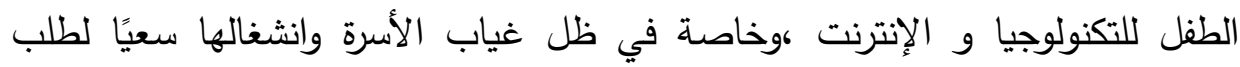
الرزق ،حيث زادت ظاهرة التفكك الأسرى وزادت الفجوة بين الأسرة والطفل وقل اهتمام الأسرة بمتابعة سلوك الطفل، وتقلص دورها في إثباع حاجاته واهتماماته أو حتى توجيهه لكيفية قضاء وقت فراغه في أمور مفيدة، وأصبح الطفل يقضي فترات طويلة أمام

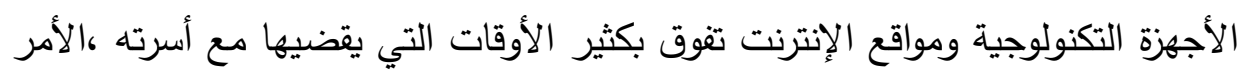

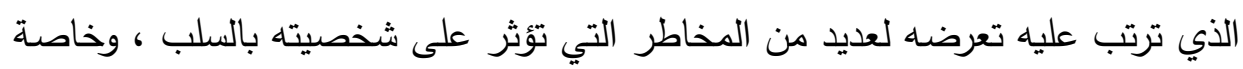


في هذه الفترة الهامة من حياته التي تتثكل فيها جوانب شخصيته، فتؤكد دراسة عزام

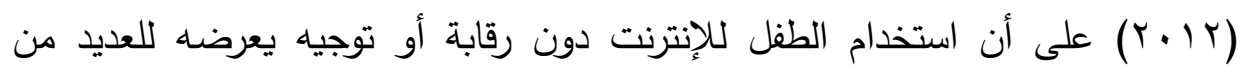

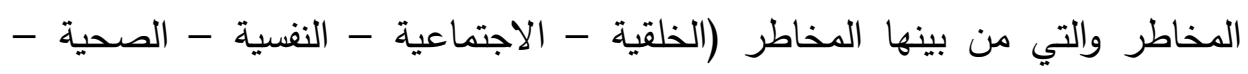
السلوكية)، كما تثير دراسة (Lenhart, Purcell, Smith,Zichuhr, 2010) أن الإنترنت من أخطر التقنيات التي يمكن من خلالها الاحتيال والنصب على على الأطفال والمراهقين من خلال عمليات البيع والثراء عبر تلك الثبكة حيث التبن انتشرت في في الآونة

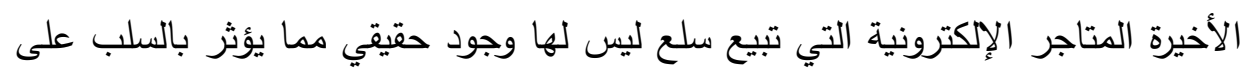
الحالة النفسية كعدم الثقة بالذات ،والثك والريبة بين مستخدمي هذه التئية لتئنية ،كما تؤكد دراسة (Quan-Haase \& Wellman, 2004) على الآثار السلبية التي تتعرض لها شخصية الطفل نتيجة استخدامه للإنترنت مثل الانطواء والعزلة وعدم الاندماج مع الثار

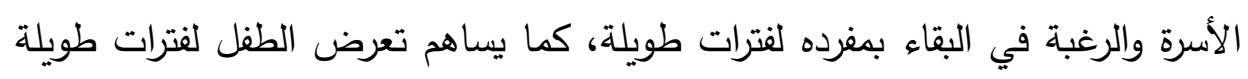
أمام شاشة الكمبيوتر على الجانب الصحي نتيجة الإثعاعات الصادرة من الأجهزة

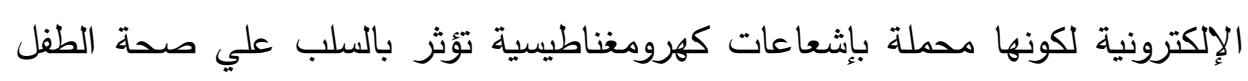
عند تعرضه لها لفترات طويلة. مشكلة الاراسة وأسئلتها

نبع الإحساس بمشكلة الدراسة الحالية من خلال النقاط الآتية:

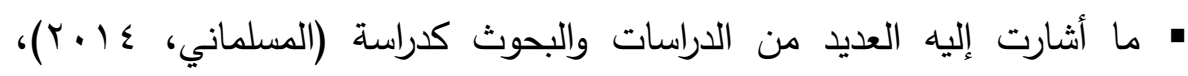

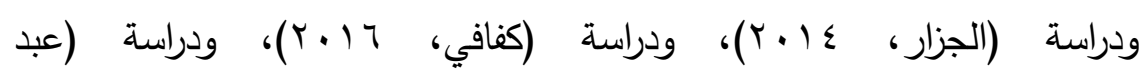

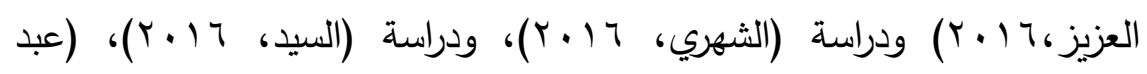

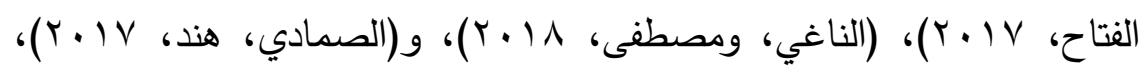

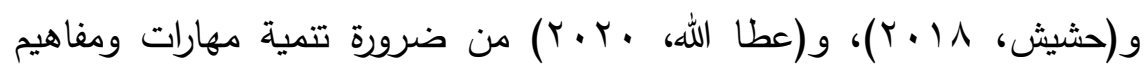

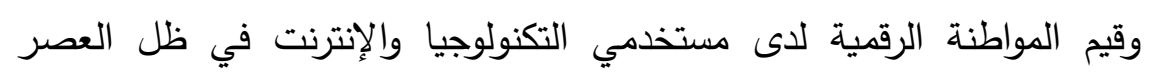

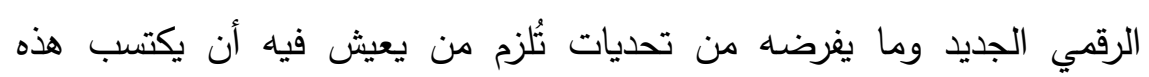

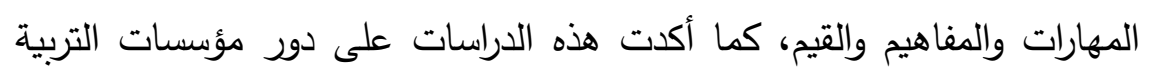




\section{مجلة " دراسات في الطفولة والتربية" - جامعة اسيوط}

التعليم في مختلف المراحل التعليمية في تتمية مفاهيم ومهارات المواطنة الرقمية لاى المتعمين كضرورة تربوية تمكنهم من العيش في المجتمع الرقمي الجديد وما يتصف به من ثورة في مجال الاتصالات وتكنولوجيا المعلومات.

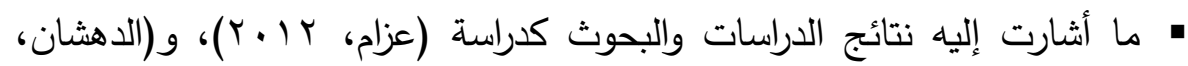

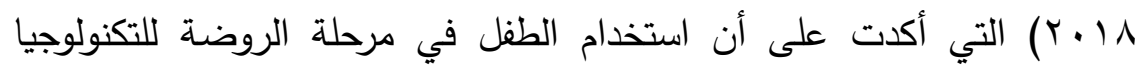
والإنترنت من دون توجيه ومتابعة الأسرة له يعرضه للعديد من المخاطر النفسية والخلقية والاجتماعية والصحية، كما أوصت بضرورة إعداد الطفل لمواجهة تحديات العصر الرقمي الجديد من خلال إكسابه مفاهيم ومهارات المواطنة

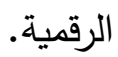

ما توصلت إليه الباحثة من خلال نتائج الدراسة الاستطلاعية التي استهدفت التعرف على مجالات استخدام الطفل للتكنولوجيا والإنترنت في هذه الماته المرحلة العمرية، وكذا استطلاع بعض مفاهيم ومهارات المواطنة الرقمية التي يمكن تتميتها لديه في هذه المرحلة، حيث طبقت الباحثة استبيان للأمهات حول بهدئ

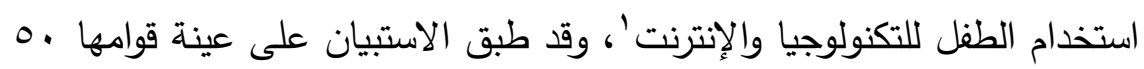

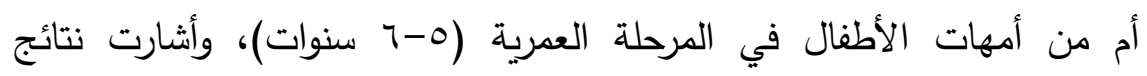
الاستبان أن . . 1\% من أطفال العينة يستخدمون الأجهزة التكنولوجية بمختلف

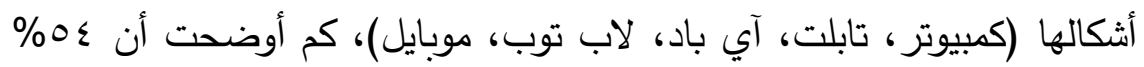

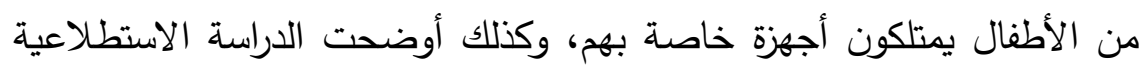
وجود قصور في مهارات المواطنة الرقمية التي تستهدف الدراسة الحالية تتميتها لاى الطفل في مرحلة الروضة، ويتضح ذلك مما يأتي: - - أشارت النتائج إلى وجود قصور في مهارات التواصل مع الآخرين من خلال الإنترنت حيث أن نسبة rr\% من الأطفال تستخدم الإنترنت

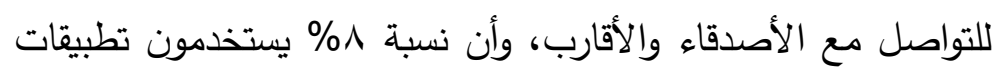

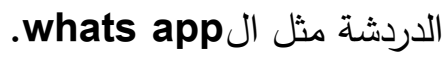


ومشاهدة الأفلام والفيديوهات، بينما يقل في استخدامه في أغراض الفال

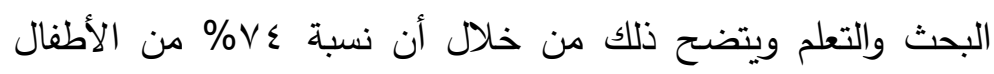

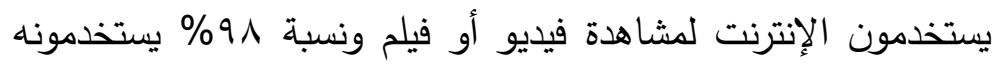

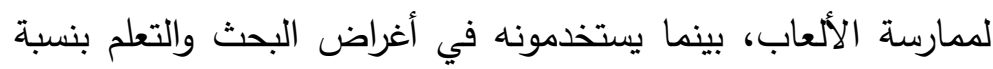
\% rᄉ

- - تشير النتائج إلى وجود قصور في بعض مهارات الصحة والسلامة

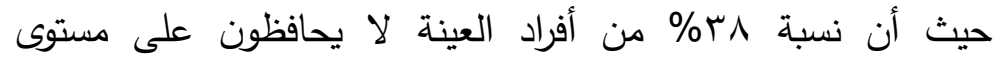
الإضاءة والصوت المناسب والآمن عند استخدام الأجهزة الإككترونية،

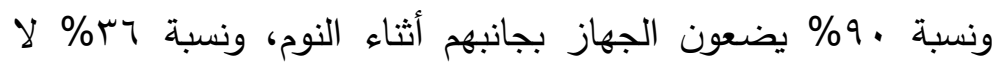

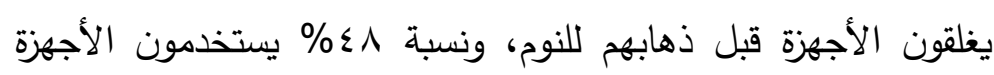
أثناء إعادة شحنها واتصالها بمصدر التيار الكهربي.

- تثير النتائج وجود قصور في بعض مهارات الأمان والخصوصية

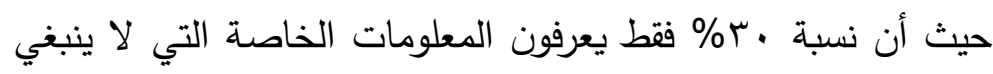

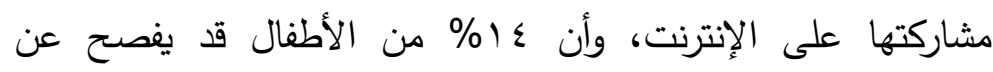

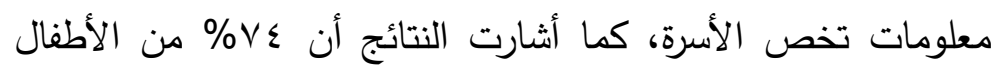

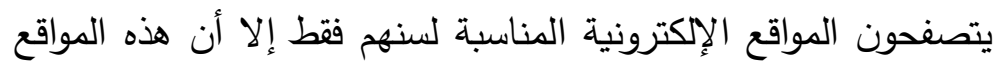

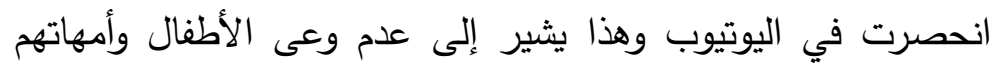

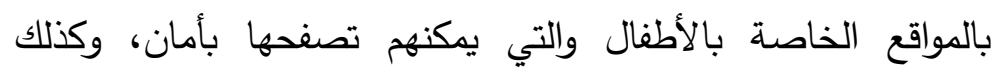

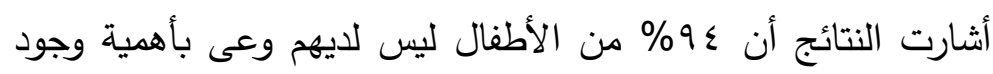
حماية ضد الفيروسات عند استخدام الإنترنت.

وانطلاقًا مما سبق عرضه، ومما تمثله أهمية مرحلة الطفولة في بناء شخصية

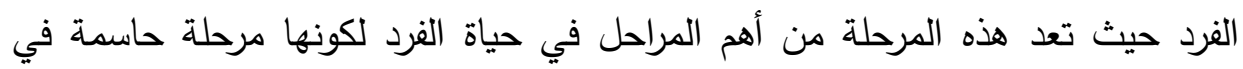

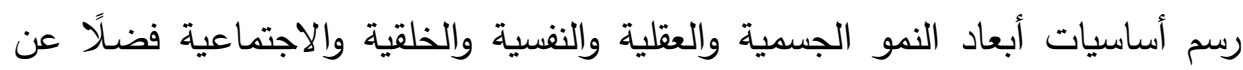

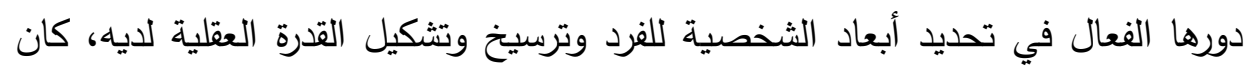




\section{مجلة " دراسات في الطفولة والتربية" - جامعة اسيوط}

من الضروري الاهتمام بتقديم مفاهيم مهارات المواطنة الرقمية للطفل في هذه المرحلة الحاسمة ليكون مواطنًا رقميًا صالحًا فيما بعد قادرًا على استخدام التقنيات الرقمية بطريقة الرئة

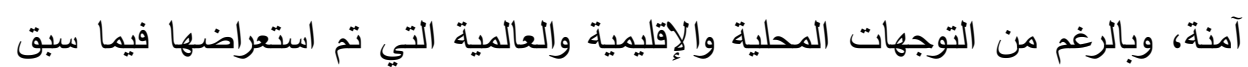
والتي تؤكد على ضرورة اعداد طفل الروضة لمواجهة تحديات العصر الرقمية من خلال

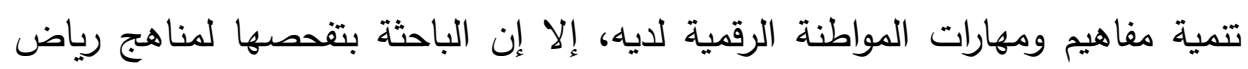
الأطفال، لاحظت أن المحتوى لم يتضمن تقديم أي مفاهيم أو مهارات خاصة بالمواطنة الرقمية، وهذا يعتبر قصورًا في مناهج رياض الأطفال في مسايرة التوجهات الراهنه. على ضوء ما سبق وما اتضح من أهمية تتمية مفاهيم ومهارات المواطنة

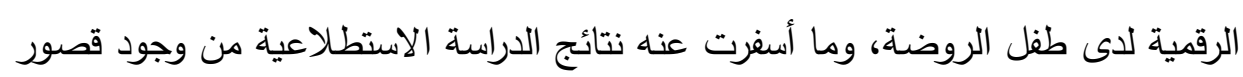

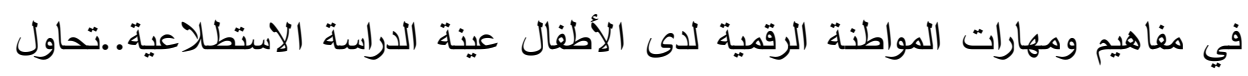
الدراسة الحالية التصدي للإجابة عن السؤال الرئيس الآتي: "ما فاعلية وحدة مقترحة في تتمية بعض مفاهيم ومهارات المواطنة الرقمية لدى طفل الروضة؟" - مل

\section{ويتفرع من هذا السؤال الرئيس الأسئلة الفرعية الآتية:}

1. ما مفاهيم ومهارات المواطنة الرقمية التي يمكن تتميتها لدى طفل الروضة؟ r. ما الوحدة المقترحة لتتمية بعض مفاهيم ومهارات المواطنة الرقمية لدى طفل

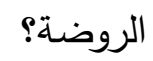
r. ما فاعلية الوحدة المقترحة في تتمية بعض مفاهيم المواطنة الرقمية لدى طفل الروضة ماعْ ع. ـ ما فاعلية الوحدة المقترحة في تتمية بعض مهارات المواطنة الرقمية لدى طفل

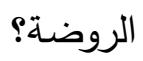




\section{فروض الدراسة}

1- توجد فرق دال إحصائيا عند مستوى الدلالة (1., ) ) بين متوسطي درجات

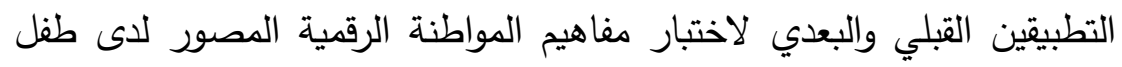
الروضة لصالح التطبيق البعدي. r- توجد فرق دال إحصائيا عند مستوى الدلالة (1., · ) بين متوسطي درجات التطبيقين القبلي والبعدي لبطاقة ملاحظة مهارات المواطنة الرقمية لدى طفل الروضة لصالح التطبيق البعدي.

ץ- للوحدة المقترحة فاعلية في تتمية بعض مفاهيم ومهارات المواطنة الرقمية لدى طفل الروضة. ع - توجد علاقة ارتباطية ذات دلالة احصائية بين درجات اختبار مفاهيم المواطنة

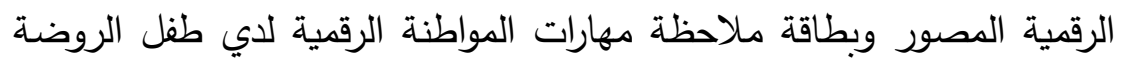
في النطبيق البعدي. أهداف الدراسة استهدفت الدراسة الحالية ما يأتي: 1. تحديد مفاهيم ومهارات المواطنة الرقمية التي يمكن تتميتها لدى طفل الروضة. r. بناء وحدة لتتمية مفاهيم ومهارات المواطنة الرقمية لدى طفل الروضة. r. التعرف على فاعلية الوحدة المقترحة في تتمية مفاهيم المواطنة الرقمية للى طفل الروضة . ـ. ـ التعرف على فاعلية الوحدة المقترحة في تتمية مهارات المواطنة الرقمية لدى طفل الروضة. 


\section{مجلة " دراسات في الطفولة والتربية" -جامعة اسيوط}

أهمية الدراسة

من بين ما يمكن أن تسهح به هذه الدراسة ما يأتي:

1. توجيه نظر معلمات رياض الأطفال والقائمين على تربية طفل الروضة، وكذا

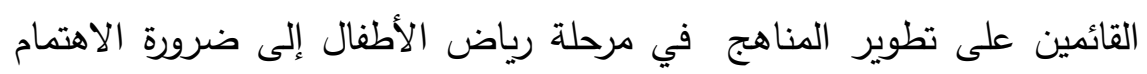

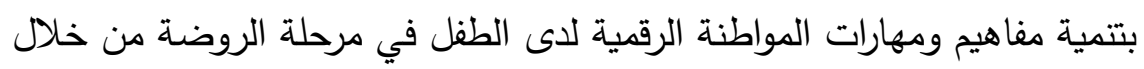

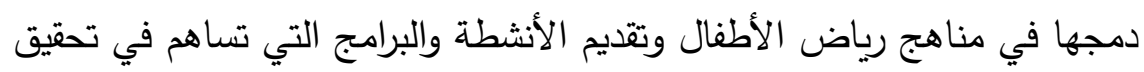
ذلك.

r. توفير أدوات بحثية جديدة يمكن أن يستفيد منها الباحثين في مجال رياض

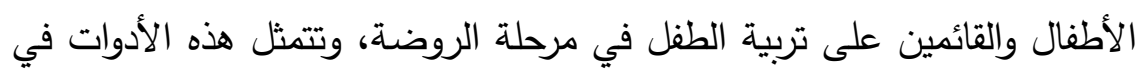
اختبار مهارات المواطنة الرقمية لطفل الروضة، بطاقة ملاحظة مهارات المواطنة الرقمية لاى طفل الروضة، الوحدة المقترحة لتتمية هذه المفاهيم والمهارات. r. تقديم بعض الأنثطة وأوراق العمل التي تفيد معلمات رياض الأطفال في تقديم مفاهيم ومهارات المواطنة الرقمية لطفل الروضة. ء. تفتح نتائج هذه الدراسة المجال أمام الباحثين في مجال رياض الأطفال لإعداد

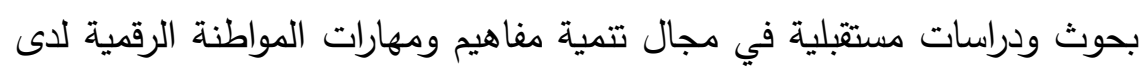
طفل الروضة. حدود الاراسة تم تتفيذ الدراسة باعتبار الحدود الآتية: 1. اقتصر تطبيق أدوات الدراسة وموادها التعليمية علي مجموعة الدراسة التي بلغ عددها (·r) طفل وطفلة من أطفال المستوي الثاني بروضة الثهيد عبد الرحمن الديب كعينة ممثلة لأطفال الروضة. 


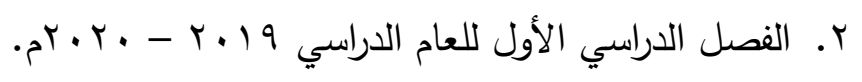

r. بعض مفاهيم المواطنة الرقمية التي تمثلت في المجتمع الافتراضي، التحدث

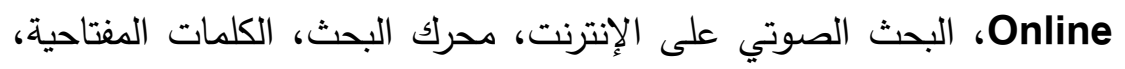
النقود الإكترونية، المحل الإكتروني، البريد الإكتروني، الرسالة الإكترونية، الإنترن،

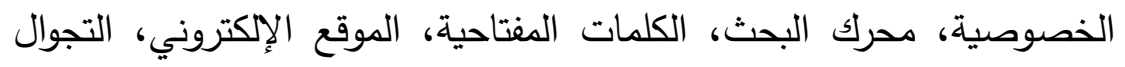
الآمن، الخصوصية، البصمة الرقمية، الفيروس الإكتروني، برنامج الحماية من البنه

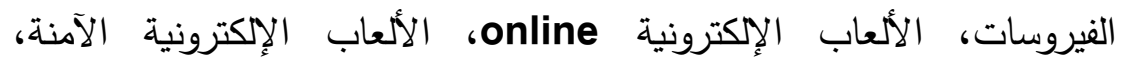

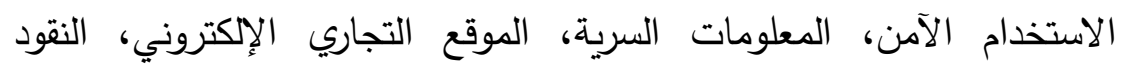
الإكترونية (بطاقة الائتمان)، المحل الإكتروني، الإعلان الإلكتروني. الإنيان.

؛. بعض مهارات المواطنة الرقمية التي تمثلت في أربع مهارات رئيسية هي: مهارة

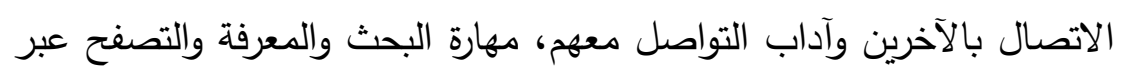
الإنترنت، مهارة الأمان والخصوصية، مهارة الصحة والسلادة.

\section{أدوات الدراسة}

$$
\text { شملت أدوات الدراسة ما يأتي: الته }
$$

ا. قائمة بمفاهيم ومهارات المواطنة الرقمية التي يمكن تتميتها لدي طفل داتل

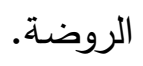

r. اختبار مفاهيم المواطنة الرقمية لاى طفل الروضة. r. بطاقة ملاحظة مهارات المواطنة الرقمية لدى طفل الروضة. ع. ـالوحدة المقترحة. منهج الدراسة استخدمت الباحثة في هذه الدراسة كلًا من: 1. المنهج الوصفي وذلك فيما يتعلق بدراسة الأدبيات والدراسات السابقة

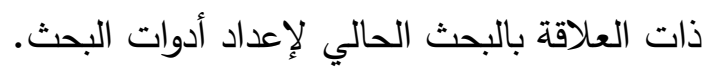




\section{مجلة " دراسات في الطفولة والتربية" - جامعة اسيوط}

r. المنهج شبه التجريبي الذي يعتمد علي التصميم قبلي - بعدي

للجموعة واحدة عند تطبيق معالجات البحث وأدواته لتحديد فاعلية الوحدة المقترحة في تتمية مفاهيم ومهارات المواطنة الرقمية لدى طفل

الروضة.

خطوات الدراسة

سارت الباحثة في الدراسة وفقاً للخطوات الآتية:

1. تحديد مشكلة الدراسة، وأهدافها، وأهميتها، وفروضها، ولاتها، وحدودها،

وخطواتها، وأهم المصطلحات المستخدمة.

r. . مسح بعض الدراسات والبحوث السابقة في مجال المواطنة الرقمية.

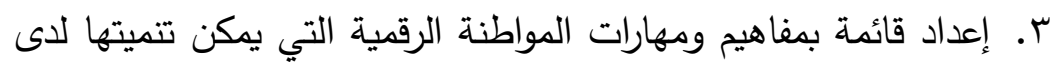
طفل الروضة وعرضها على السادة المحكمين. ء. إعداد الوحدة المقترحة لتتمية مفاهيم ومهارات المواطنة الرقمية لدى لرى

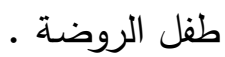

0. إعداد اختبار مفاهيم المواطنة الرقمية المصور وعرضه على السادة

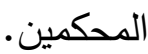

7. إعداد بطاقة ملاحظة مهارات المواطنة الرقمية (داخل الروضة)وعرضها على السادة المحكمين.

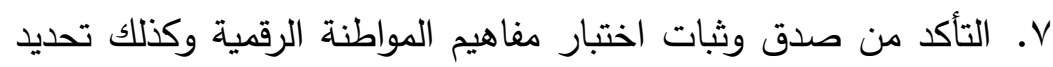

زمن الاختبار من خلال تطبيقه استطلاعيًا.

^. التأكد من صدق وثبات بطاقة الملاحظة.

9. تطبيق اختبار مفاهيم المواطنة الرقمية وبطاقة ملاحظة مهارات

المواطنة الرقمية على عينة الدراسة تطبيقًا قبليًا.

• ا.تطبيق أنثطة الوحدة المقترحة لتمية مفاهيم ومهارات المواطنة الرقمية مع الأطفال عينة الدراسة. 
1 ا.تطبيق اختبار مفاهيم المواطنة الرقمية وبطاقة ملاحظة المهارات بعديًا على الأطفال عينة الدراسة.

$$
\text { Y (.رصد النتائج ومعالجتها إحصائياً وتفسيرها. }
$$

با (.تقديم التوصيات والمقترحات بناء على نتائج الدراسة.

$$
\text { المواطنة الرقمية }
$$

يُقصد بها في الدراسة الحالية امتلاك الأطفال عينة الدراسة لمعارف ومهارات

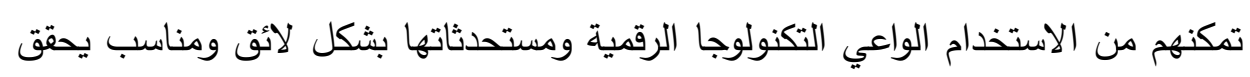
لهم الأمن والسلامة لأنفهم والآخرين. مفاهيم المواطنة الرقمية

يُقصد بها في هذه الدراسة مجموعة الصور العقلية المتعلقة باستخدام التكنولوجيا الرقمية ومستحدثاتها والتي تتكون لدى الطفل نتيجة مروره بأنشطة

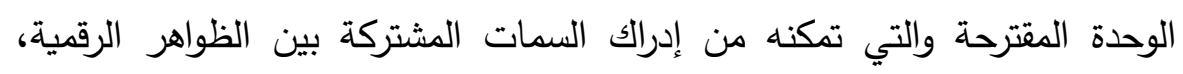

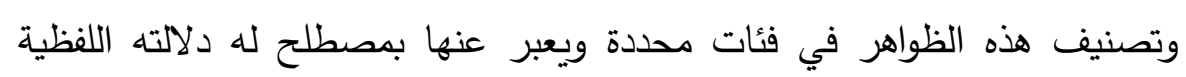
وتقدر احصائيًا بمجموع الدرجات التي يحصل عليها الطفل في اختبار مفاهيم المواطنة الرقمية المصور المُعد في الدراسة الحالية ومن أمثلة هذه المفاهيم: المجتمع الافتراضي، التحدث Online، البحث الصوتي على الإنترنت، محرك التك البحث، الكلمات المفتاحية، النقود الإلكترونية. مهارات المواطنة الرقمية 


\section{مجلة " دراسات في الطفولة والتربية" - جامعة اسيوط}

يُقصد بها في الدراسة الحالية تمكن الطفل من أداء بعض المهام المرتبطة

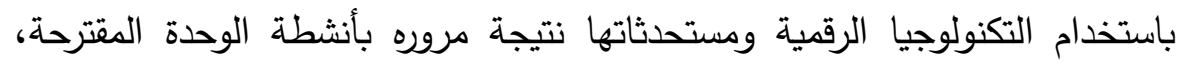
وتُقّدر احصائيًا بمجموع الدرجات التي يحصل عليها الطفل بعد أداء المهارات المتضمنة في بطاقة ملاحظة مهارات المواطنة الرقمية المُعدة في الدراسة الحالية ومن أمثلة هذه المهارات: استخدام الإنترنت في البحث عن المعرفة، والمحافظة على بياناته الخاصة أثناء الاتصال بالإنترنت، وتصفح المواقع الآكترونية المناسبة الإنرنة لسنه، والمحافظة على مستوى الإضاءة والصوت المناسب أثثاء استخدام اجهزة الإنهاء التكنولوجية.

\section{الإطار النظري والدراسات السابقة}

أولًا: المواطنة الرقمية ( مفهومها، و عناصرها):

ظهر مصطلح المواطنة الرقمية (Digital Citizenship) كانعكاس لما يتطلبه العصر الرقمي الذي يعيش فيه الإنسان اليوم من أن يكون على وعي ودراية

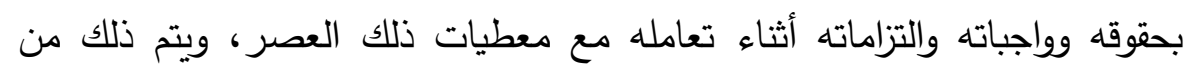
خلال المواطنة الرقمية التي تمكنه من فهم كيفية استخدام التقنيات الرقمية بطريقة آمنة، وخلقية، وقانونية ليكون مواطنًا رقيًا صالحًا ومتعلمًا مدى الحياة.

وتُعرف المواطنة الرقمية بأنها تفاعل الفرد مع غيره باستخدام الأدوات

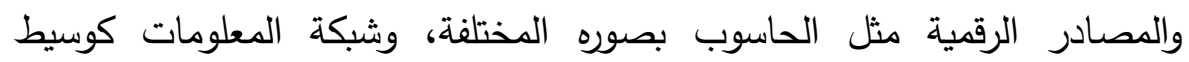

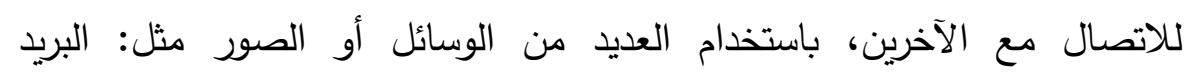

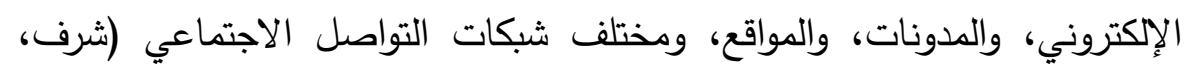

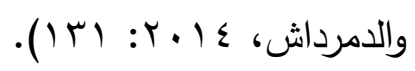

كما تعرف بأنها قواعد السلوك المعتمدة في استخدامات التكنولوجيا المتعددة، مثل استخدامها من أجل التبادل الإكتروني للمعلومات، والمشاركة الإكترونية الكاملة في في في في المجتمع، وشراء وبيع البضائع عن طريق الإنترنت، وغير ذللك، بحيث يكون المواطن 
الرقمي هو المواطن القادر على استخدام شبكات الإنترنت وتقعيلها داخل المجتمع الذي

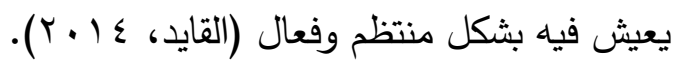

كما تعرف بأنها مجموعة من القواعد والضوابط والمعايير والأعراف والأفكار والمبادئ المتبعة في الاستخدام الأمثل والقويم للتكنولوجيا الرقمية، والتي يحتاج إليها المواطنون صغارًا وكبارًا أثناء التعامل مع تقنياتها من أجل استخدامها بطريقة مناسبة الدية وآمنة وذكية ، وبما يؤدي للمساهمة في رقي الوطن، ومن خلال عمليات الإتاحة العادلة

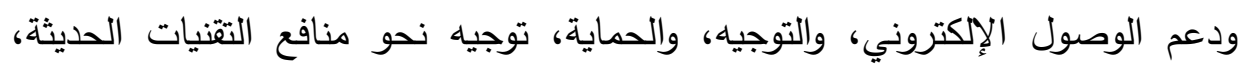

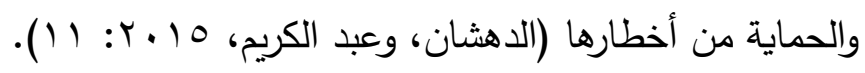

وتعرف المواطنة الرقمية بمجموعة المهارات والمعارف وقواعد السلوك التي يحتاجها كل من يتعامل مع الوسائل التكنولوجية ليحترم نفسه والآخرين، ويتعلم ويتواصل

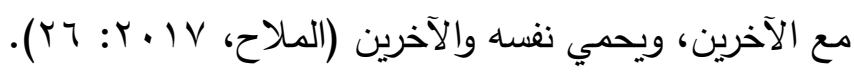

كما تعرف المواطنة الرقمية بأنها مجموعة من القيم المتبعة في الاستخدام

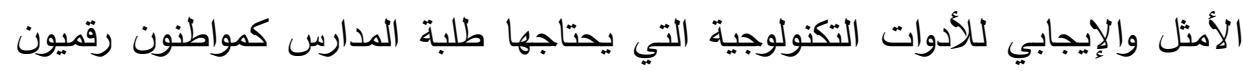
بغض النظر عن فئاتهم العمرية ومستوياتهم الثقافية صغاراً أم كبارا، من أجل المساهمة الإنة

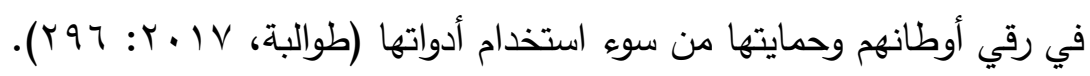

فالمواطنة الرقمية ليس الهدف منها مجرد وضع الحدود والعراقيل من أجل التحكم والقهع ضد مستخدمي التكنولوجيا، بل هي طريقة لتوجيه وحماية المستخدمين من الثباب والأطفال وتوعيتهم بمنافع التكنولوجيا الحديثة والحماية من أخطارها، ومساعدتهم على التعامل مع التكنولوجيا من خلال مبادئ الاحترام، والتعليم، والحماية.

وفي ضوء ما تقدم من تعريف للمواطنة الرقمية يمكن تحديد خصائص هذا

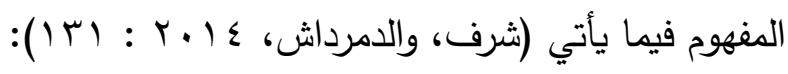

$$
\begin{aligned}
& \text {, , الوعي بالعالم الرقمي ومكوناته. }
\end{aligned}
$$




\section{مجلة " دراسات في الطفولة والتربية" - جامعة اسيوط}

r. امتلاك مهارات الممارسة الفعالة والمناسبة في استخدامات العالم الرقمي

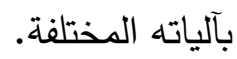

r. اتباع القواعد الخلقية التي تجعل السلوك التكنولوجي للشخص يتسم بالمقبولية الاجتماعية في التقاعل مع الآخرين.

ولكي يتم تزويد المتعلمين بالمؤشرات اللازمة لاكسابهم مفاهيم المواطنة الرقمية

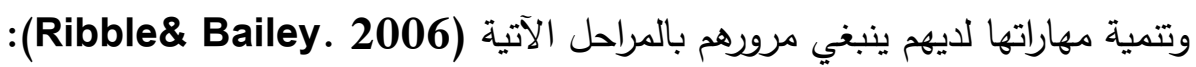

1- مرحله الوعي: وتعني تزويد الطلبة بما يؤهلهم ليصبحوا مثقين بالوسائط

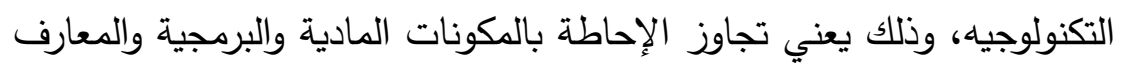
الأساسية، انتقالًا لمرحلة تبصر الاستخدامات غير المرغوبة لتلك التكنولوجيا. ץ- مرحلة الممارسة الموجهة: وتعني بالمقدرة على استخدام التكنولوجيا في مناخ

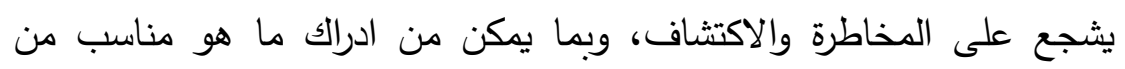
الاستخدامات التكنولوجية وما هو من غير مناسب.

r- مرحلة النمذجة: من خلال تقديم النموذج والقدوة الإيجابية حول كيفية استخدام التكنولوجيا أثناء تواصلهم مع الآخرين.

ع- مرحلة التغذية الراجعة وتحليل السلوك: من خلال إتاحة الفرصة للمتعلمين لمناقثة استخدامهم للتقنية الرقمية في مواقف التعليم والتعلم المختلفة، ووصولهم إلى امتلاك القدرة على التمييز بين الاستخدام السليم وغير السليم للتكنولوجيا داخل صفوفهم الدراسية.

\section{عناصر المواطنة الرقمية: - م}

إن عناصر المواطنة الرقمية تعد بمثابة المحددات الثقافية والاجتماعية والصحية والقانونية والأمنية ذات الصلة بالتكنولوجيا، والتي تمكن مستخدميها من تحديد معايير السلوك الأخلاقية المقبولة أثناء التعامل مع التكنولوجيا بما يمكنهم من مسايرة

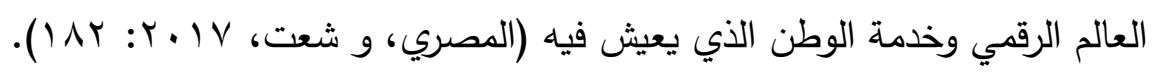




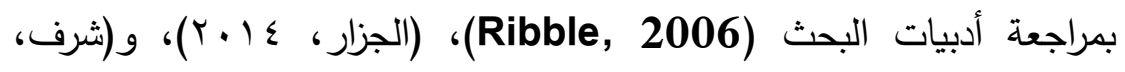

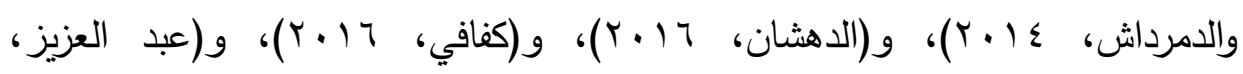

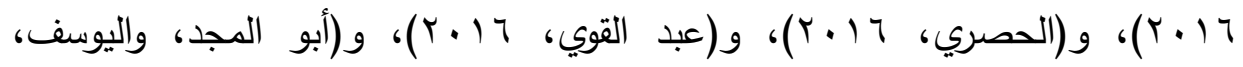

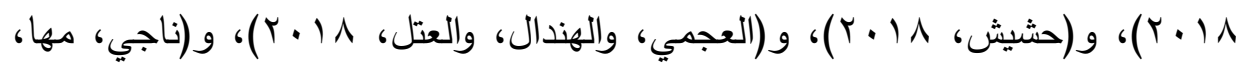

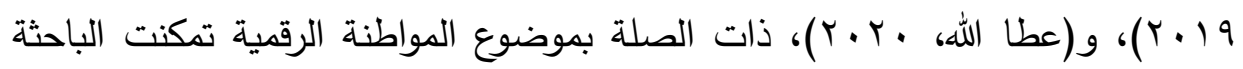
من تحديد العناصر التسعة الآتية كعناصر أو مجالات دلات للمواطنة الرقمية:

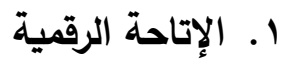

تثير الإتاحة الرقمية إلى توافر فرص متساوية لكل مواطن رقمي لاستخدام التكنولوجيا، بغض النظر عن مستواه الاقتصادي، والاجتماعي، والتعليمي، وعلى الرغم

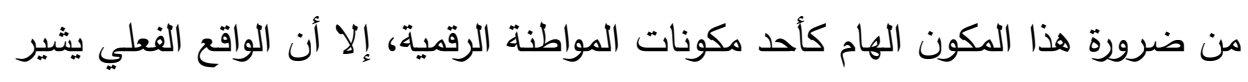

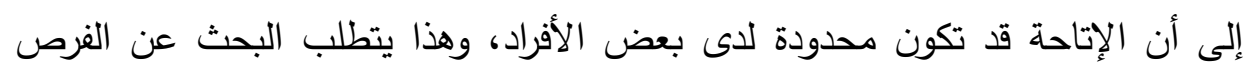
والبدائل التي تحقق الإتاحة الرقمية لكل مواطن رقمي.

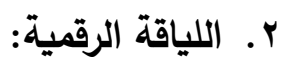

تثير اللياقة الرقمية إلى اتباع المواطن الرقمي آداب السلوك القويم والتزامة

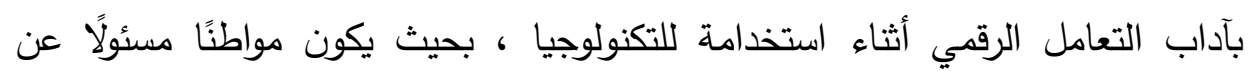

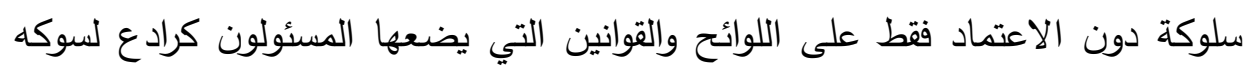
غير القويم.

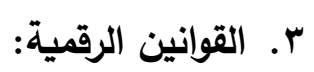

تثير إلى وعي المواطن الرقمي أن الاستخدام غير الأخلاقي للتكنولوجيا مثل

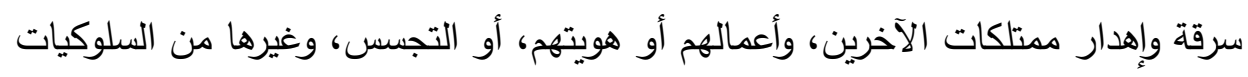

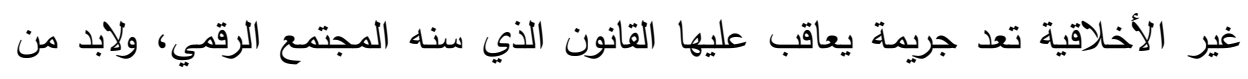
الانتباة لهذه القوانين والالتزام بها. 


\section{مجلة " دراسات في الطفولة والتربية" - جامعة اسيوط}

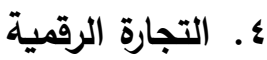

تشير إلى وعي المواطن الرقمي بأن عمليتي البيع والثراء للبضائع والمستلزمات المختلفة قد تتم من خلال الوسائط التكنولوجية المختلفة، ولكي يتم ذلك ينبغي توعيت وليته

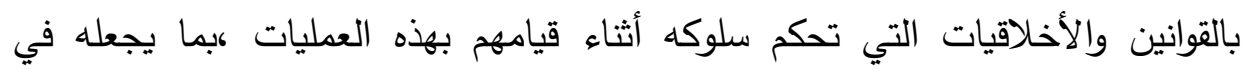
النهاية مستهلك فعال في عالم جديد من الاقتصاد الرقمي.

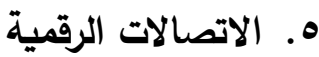

تشير إلى تعليم وتدريب المواطن الرقمي علي معرفة الخيارات المناسبة أثناء

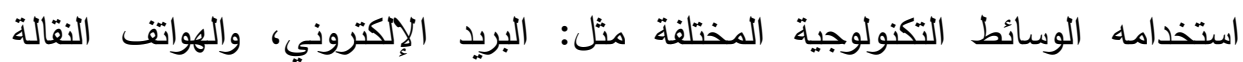
والرسائل الفورية، وغيرها من التطبيقات العديدة التي يستخدمها للتواصل والتعاون مع غيره من الأفراد مهما بعدت الأماكن وتباينت الأوقات.

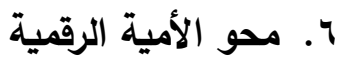

تشير إلى تعليم وتدريب المواطن الرقمي كيف يتعلم في ظل مجتمع رقمي سريع

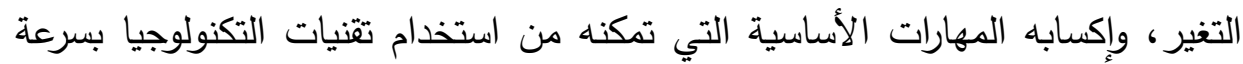
فائقة وكفاءة عالية في حياتة اليومية وتوظيفها ليتعلم أي شيء في أي وقت وأي مكان.

\section{V. الحقوق والمسئوليات الرقمية}

تثير إلى توعية المواطن الرقمي بأن له الحق في التمتع بالحرية والخصوصية

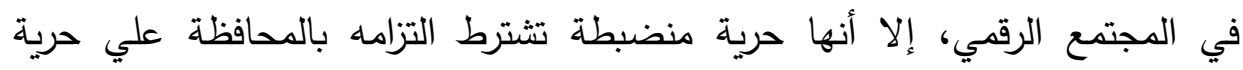
وخصوصية الآخرين، فإذا أراد أن يحافظ على حقوقه ينبغي أن يحافظ على واجباته تجاه الآخرين ممن يعيشون معه في المجتمع الرقمي.

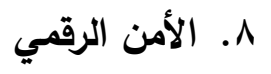

تشير إلى توعية المواطن الرقمي بضرورة المحافظة على خصوصية معلوماتة

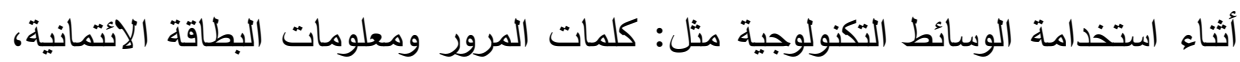
وغيرها .... ، وأن يكون على وعي بالمخاطر المترتبة على السماح للأشخاص الآخرين 
الحصول عليها، واتخاذ التدابير الأمنية اللازمة لحماية هذه المعلومات والبيانات من

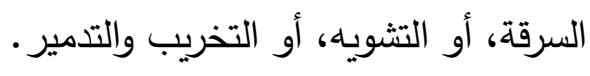

\section{9 ـ الصحة والسلامة الرقمية}

تثير إلى توعية وتدريب المواطن الرقمي على الاستخدام الأمثل والمناسب

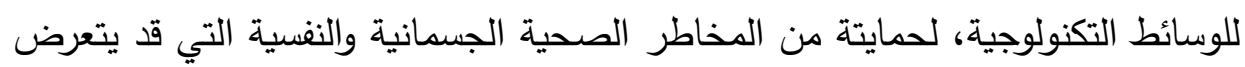
لها نتيجة استخدامه للتكنولوجيا بطريقة غير مناسبة. ثانيًا:أهمية المواطنة الرقمية:

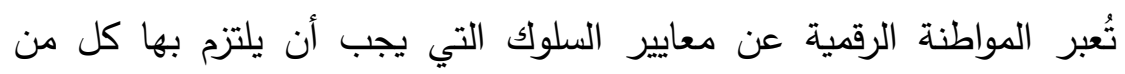

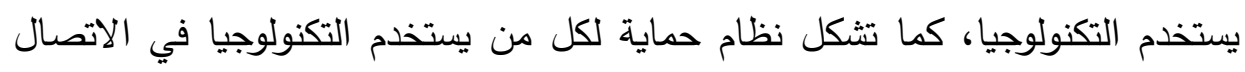

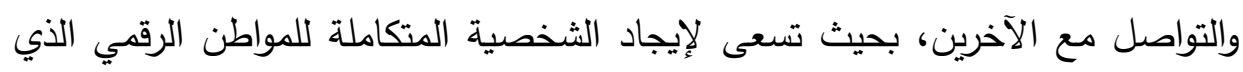

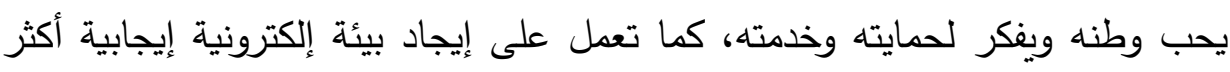
أمنًا وسلامًا لمستخدميها، كما تعمل على توفير الأساس الذي يقوم عليه المجتمع الرقمي

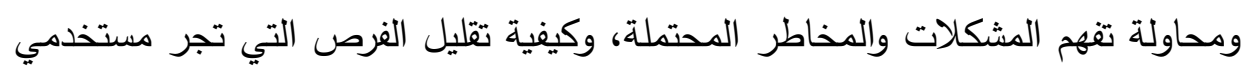
التكنولوجيا إلى مشكلات استخدام التكنولوجيا استخدامًا سينًا.

إن ما يموج به عالمنا اليوم من مخاطر الاجتياح الرقمي يؤكد على أن المواطنة

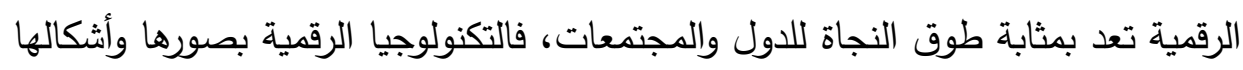
المختلفة يمكن أن تكون الجسر نحو المعرفة الجديدة، وإثراء العملية التربوية، وتجديد

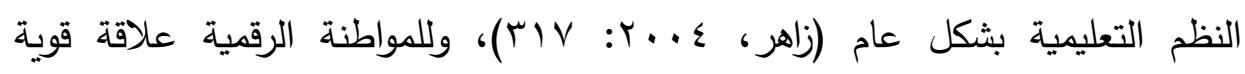
بمنظومة التعليم فهي ليست مجرد أداة تعليمية بل وسيلة لمساعدة المتعلمين في الإنخراط الكامل في المجتمع والمشاركة الفعالة في خدمة مصالح الوطن عمومًا، وفي المجال

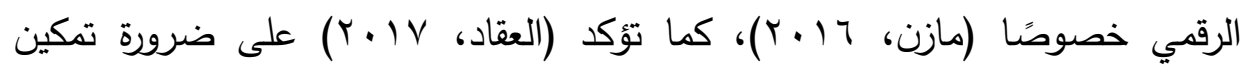
القائمين على العملية التعليمية وخاصة المعلمين من توظيف متطلبات المواطنة الرقمية في التعليم. 


\section{مجلة " دراسات في الطفولة والتربية" - جامعة اسيوط}

وتتضح أهمية المواطنة الرقمية من خلا ما تثير إلية الجمعية الدولية للتكنولوجيا في التعليم ISTE إلى ضرورة مراعاة المؤسسات التعليمية لعدة معايير لتتمية قدرة المتعلمين والمعلمين على استخدام التكنولوجيا في التعليم لتجعلهم مواطنين رقميين قادريين على التعرف على حقوقهم وواجباتهم والعيش والتعلم والعمل في مجتمع رقمي مترابط، كما تساعدهم على التصرف بطرق آمنة وقانونية وأخلاقية أثناء استخدام التكنولوجيا وهذه المعايير هي (Ribble, Bailey, \& Ross, 2004:7):

- مساعدة المتعلمين على فهم الأخلاق والقضايا الثقافية والمجتمعية ذات الصلة بالتكنولوجيا.

- تدريهم على الاستخدام المسئول والقانوني والأخلاقي لنظم تكنولوجيا المعلومات والبرمجيات.

- تمية اتجاهات إيجابية لدى المتعلمين واكتسابهم السلوك الإيجابي نحو استخدام التطبيقات والبرامج التكنولوجية التي تدعم التعلم مدى الحياة.

وعلى الرغم من الفوائد والمميزات التي قدمتها المستحدثات التكنولوجية لمستخدميها إلا أنها ساهمت في ظهور العديد من الآثار السلبية كطمس الثقافيات القومية، والقضاء على خصوصيتها، وفرض ثقافات دخلية على المجتمعات، وانتثار

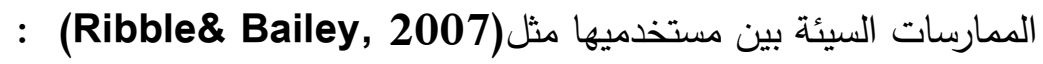
- - استخدام الهواتف الخلوية في الأماكن المزدحمة. - - - - مرض مواد إباحية على شبكة الإنترنت. - - ممارسة الألعاب الإلكترونية على الهواتف المحمولة داخل الفصل الدراسي. - - مرقة معلومات من خلا الإنترنت. - - تحميل بعض البرامج بطريقة غير مشروعة من على شبكة الإنترنت. 
هذا وقد قامت العديد من المنظمات العامة والخاصة في عدة دول ومن بينها مصر بعدة جهود من شأنها توفير مجموعة من الحلول التكنولولجية من أجل تقديم العون لمستخدمي شبكة الإنترنت وتوفير عناصر الأمن والسلامة لهم ولأطفالهم أثناء

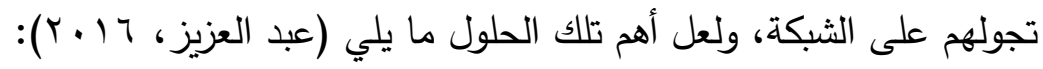
1- الخطوط الساخنة التي تقوم بتلقي بلاغات الجرائم أو التهديدات التي قد تواجه الأطفال على الإنترنت.

r- نظام الثبكة الآمنة الذي هو عبارة عن تقنية عالمية مشهورة تستخدم مواقع متقدمة وتقنيات متميزة في حجب المواقع الإباحية للأطفال. r- أدوات الحظر المستخدمة في حماية الأطفال مثل (إنترنت الأسرة) وهى أداة تكنولوجية موجهة للآباء وأولياء الأمور تعمل على حجب التهابل المواقع التي

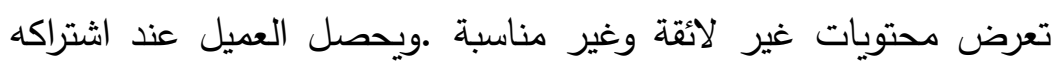
في هذه الخدمة على اسم مستخدم وكلمة مرور تمكنه من مراقبة المحتويات الإباحية أو البذيئة المعروضة فلى على الإنترنت.

ع- إقامة العديد من المؤتمرات والندوات وورش العمل التي تؤكد على ضرورة حماية الأطفال والثباب من الأضرار الناجمة عن استخدام الإنترنت وكيفية ولندية الحماية من هذه الأخطار . الأطفاب من

0- سن العديد من القوانين والتشريعات التي تعاقب جرائم التكنولوجيا والإنترنت.

צ- تضمين المناهج التعليمية في المراحل التعليمية المختلفة بعض المقررات

$$
\text { التي تتناول تدريس التكنولوجيا والإنترنت. }
$$

هذا وعلى الرغم من الإجراءات والتدابير التي اتخذتها الدول لحماية مستخدمي التكنولوجيا، إلا أن المؤسسات التربوية يقع عليها العبء الأكبر في تتشئة وإعداد المواطن

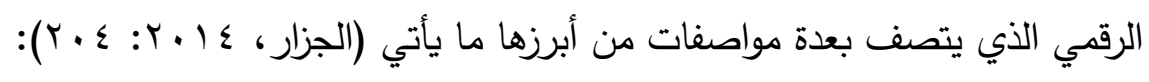




\section{مجلة " دراسات في الطفولة والتربية" - جامعة اسيوط}

1- المحافظة على معلوماته الثخصية.

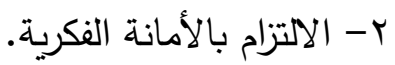

r- القدرة على إدارة الوقت الذي يقضيه في استخدام الوسائط الرقمية.

ع- الوقوف ضد التسلط عبر الإنترنت.

0- احترام الثقافات والمجتمعات في البيئة الافتراضية.

צ- حماية نفسه من المعتقدات الفاسدة التي تتنشر عبر الوسائط الرقمية.

ويُعرف المواطن الرقمي بأنة "هو المواطن الذي يتبع قواعد السلوك المناسب

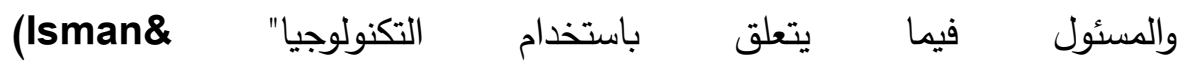

.Gungoren.2013:551)

كما يُعرف المواطن الرقمي بأنه الإنسان الذي ولد في عصر الثورة التكنولوجية، وتفاعل مع التكنولوجيا الرقمية في مرحلة مبكرة من عمره ولديه قدرة على الإمام بالمفاهيم والمهارات الخاصة بها، كما يفهم قيمة التكنولوجيا الرقمية ويقدرها ويوظفها مئها

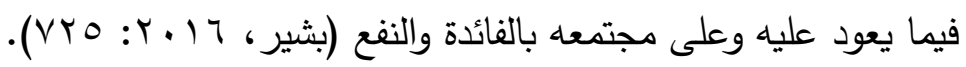

وتشير دراسة (Winther. 2017) أن استخدام الأطفال للإنترنت بصورة

مقننة وبوقت محدد يزيد من النمو العقلي لديهم، كما يساهم في نمو العلاقات

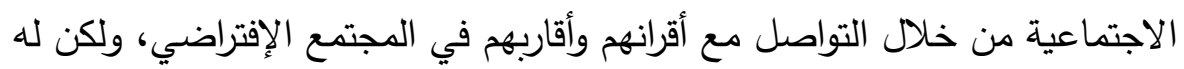
تأثير سلبي على ممارستهم للأنشطة الرياضية وخاصة عند الجلوس لساعات طويلة أمام الإنترنت، في حين أن الإفراط في استخدام الأطفال للإنترنت للة تأثير سلبي لني على نموهم العقلي والاجتماعي.

إن تزويد المتعلمين بالمهارات اللازمة التي تمكنهم من استخدام الإنترنت بطرق

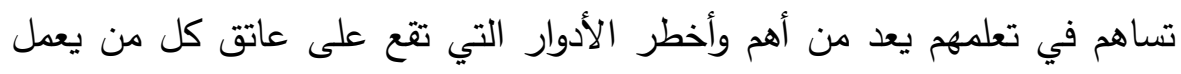

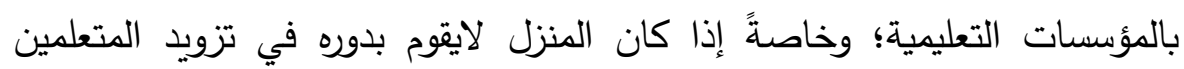


بمفاهيم وسلوكيات ومهارات تمكنهم من أن يكونوا مواطنين رقميين مسئوليين وآمنين عند استخدامهم التكنولوجيا (CouroS \& Hildebrandt. 2015: وتثير (Farmer, 2011) إلى أنه مع تقدم التكنولوجيا وإتاحة الإنترنت لقطاع كبير من المواطنين زاد معدل الجرائم التي ترتكب باستخدام الإنترنت على التى

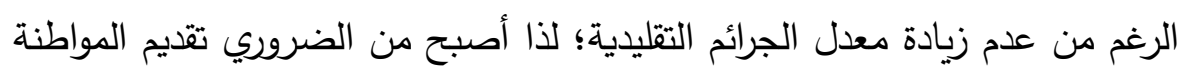

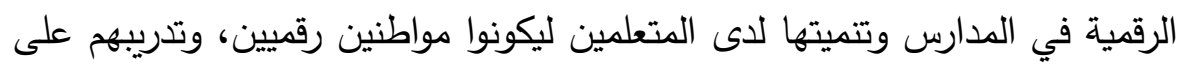

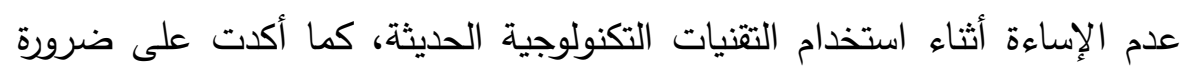
توافر استراتيجيات لتعليم المواطنة الرقمية في المؤسسات التعليمية.

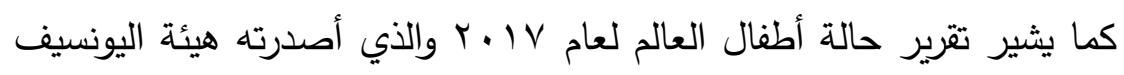
إلي ضرورة توافر العديد من المبادئ والإجراءات والتدابير التي تمكن أطفال اليوم من أن يصبحوا مواطنين رقميين في الغد قادرين على شق طريقهم وسط الكم الهائل

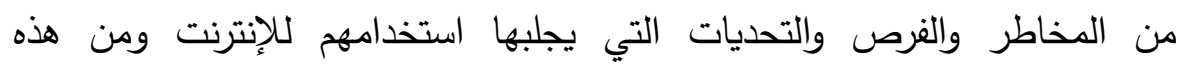

$$
\text { الإجراءات ما يأتي: }
$$

- إتاحة الفرصة لجميع الأطفال للوصول إلى موارد عالية الجودة على الإنى

$$
\text { الإنترنت وبأسعار معقولة. }
$$

- حماية الأطفال من التعرض للأذى أثناء استخدامهم للإنترنت ودعم جهود إنفاذ القانون الخاص بحماية الطفل.

- حماية خصوصية وهويات الأطفال على الإنترنت ووضع ضمانات لحماية خصوصية الأطفال ومعلوماتهم الثخصية وسمعتهم وعدم استغلال

$$
\text { بياناتهم الثخصية لتحقيق مكاسب تجارية. }
$$

- محو الأمية الرقمية لإبقاء الأطفال مطلعين ومشاركين وآمنين على الإنى الإنترنت من خلال تعليم محو الأمية الرقمية في المدارس ودمج برامج الإبعاء

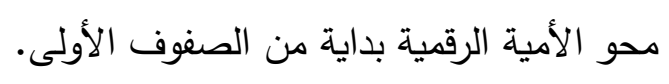




\section{مجلة " دراسات في الطفولة والتربية" - جامعة اسيوط}

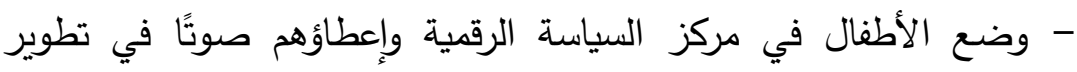
السياسات الرقمية التي تشكل حياتهم (منظمة الأمم المتحد للطفولة

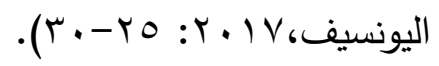

وأثارت دراسة (Hollandsworth, Donovan, \&Welch, 2017) إلى (الى ضرورة تتمية مفاهيم ومهارات المواطنة الرقمية في المراحل التعليمية الأولى والمتعلمين في سن مبكرة، وضرورة تحسين الوعى بالمواطنة الرقمية من قبل

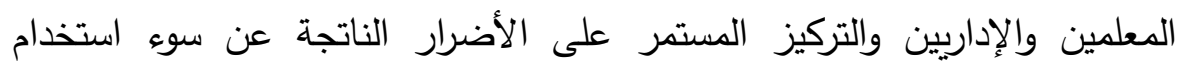

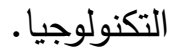

كما تشير دراسة (Decarlo, Grant, Lee, Neuman.2017) إلى ضرورة محو الأمية الرقمية لدى المتعلمين وخاصة في مرحلة رياض الأطفال من

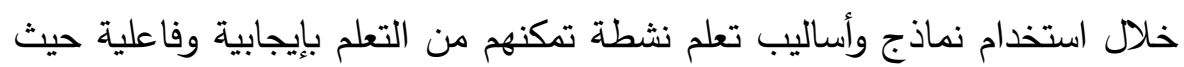
استخدمت هذه الدراسة نموذج I-LEARN الذي يعتمد على ستة محاور وهي: - - - مديد المشكلة والتركيز على السؤال. - - تحديد المعلومات المطلوبة لحل المشكلة أو الإجابة عن السؤال من خلال البحث واستخراج المعلومات ذات الصلة بالمشكلة والسؤال. - - تقييم المعلومات لتحديد أهميتها لحل المشكلة أو الإجابة عن السؤال.

$$
\text { - - - مبيق المعلومات على المشكلة أو السؤال. }
$$

- المعرفة من خلال تخصيص واستيعاب المعلومات التي تم البحث عنها والتوصل إليها.

إن ما يتصف بع عالمنا اليوم من الإتاحة الرقمية للمتعلمين في مختلف المراحل

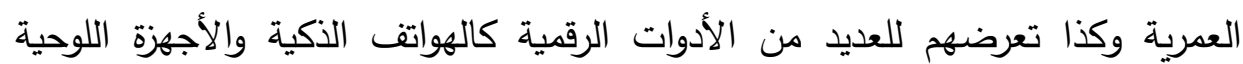
وتطبيقات الثبكات الاجتماعية المختلفة فرض على كل من يشارك في عملية تربية 
وتعليم النشئ أن يكون على وعي ودراية بمفاهيم ومهارات المواطنة الرقمية ولا يتوقف

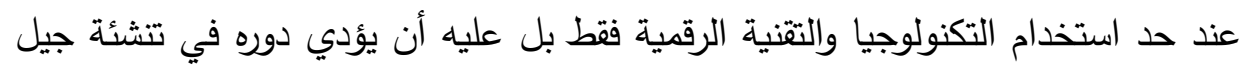
من المواطنين الرقميين الملتزميين بمعايير السلوك المناسب والمسئول فيما يتعلق باستخدام التكنولوجيا (Ribble, 2012 )، وهذا يفرض على المربيين الاهتمام بالقضايا الهامة ذات الصلة بإعداد الطلاب كمواطنين رقميين مثل: بيئة التعلم، والمداخل التربوية، أمان الطالب، الخصوصية، المسئولية العالمية، إدارة الهوية، الأمن المعلوماتي لئي (Alberta Education,2012: 20)، كما يتطلب ضرورة إدماج محو الأمية الرقمية والمواطنة الرقمية في المناهج الدراسية وبرامج الأنشطة والدورات التي التي تقدم

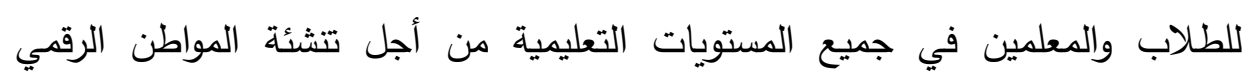
العالمي (Gazi, 2016). إجراءات الاراسة:

إعداد قائمة بمفاهيم ومهارات المواطنة الرقمية التي يمكن تنميتها لطفل

الروضة.

للإجابة عن السؤال الأول من أسئلة الدراسة وهو: "ما مفاهيم ومهارات المواطنة الرقمية التي يمكن تتميتها لطفل الروضة؟" قامت الباحثة بالخطوات الآتية:

ا. الاطلاع على العديد من البحوث والدراسات ذات الصلة بموضوع الدراسة لتحديد مفاهيم ومهارات المواطنة الرقمية التي يمكن تتميتها لطفل الروضة التهات

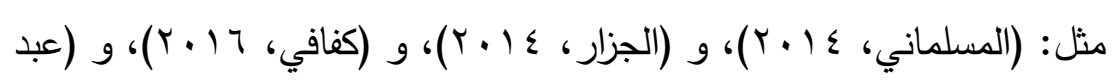

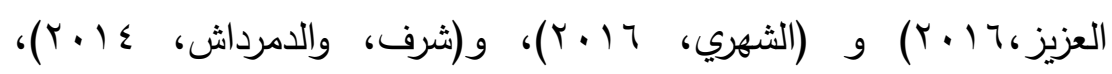

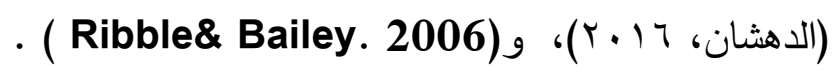
r. إعداد قائمة مبدئية بمفاهيم ومهارات المواطنة الرقمية لطفل الروضة. r. عرض القائمة على مجموعة من أعضاء هيئة التدريس المتخصصين في لرئية

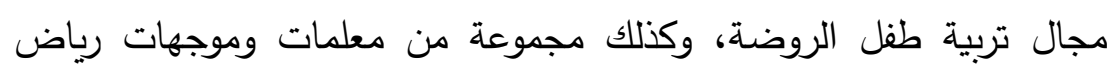
الأطفال؛ وذلك للتأكد من مدى مناسبة تلك المفاهيم والمهارات لطفل الروضة. 


$$
\text { مجلة " دراسات في الطفولة والتربية" - جامعة اسيوط }
$$

ـ. على ضوء توجيهات وتعديلات السـادة الخبراء والمتخصصين تم إعداد قائمـة

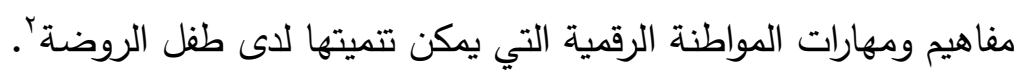

إعداد الوحدة المقترحة لتنمية بعض مفاهيم و مهارات المواطنة الرقمية لاى

طفل الروضة

للإجابة عن السؤال الثاني من أسئلة الدراسة وهو: "ما الوحدة المقترحة لتتمية

بعض مفاهيم مهارات المواطنة الرقمية لطفل الروضة؟" قامت الباحثة بما يأتي:

بناء وحدة المواطنة الرقمية لطفل الروضة في ضوء المبادئ الآتية:

I ـ إن طفل الروضة ليس لديه خبرة سابقة في موضوعات المواطنة الرقمية.

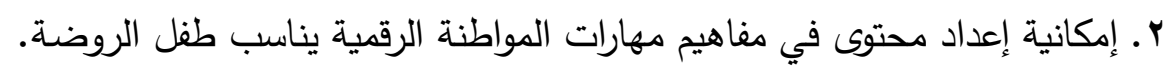
r. تأكيد العديد من الدراسات على أهمية وضرورة تدريس مفاهيم مهارات المواطنة

$$
\text { الرقمية لطفل الروضة. }
$$

بناء أنشطة الوحدة المقترحة في ضوء عدة أسس هي:

ا-أن يرتبط محتوى الأنثطة بالهدف الذي صممت من أجله.

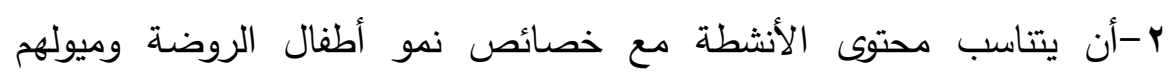

وقدراتهم.

ץ-أن تتتوع الأنشطة لمراعاة الفروق الفردية بين الأطفال.

ع -أن تكون الأنشطة جذابة وممتعة وتزيد من المشاركة الفعالة للطفل في عملية

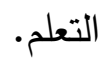

ه-أن تتدرج الأنشطة من البسيط للمركب ومن السهل للصعب.

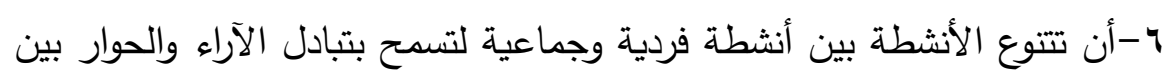
الأطفال.

V - أن تتوافر في الأنشطة عوامل الأمن والسلامة للطفل.

^-أن ترتبط الأنشطة بالمواقف الحياتية للطفل.

r ملحق(T):الصورة النهائية لقائمة مفاهيم وممارات المواطنة الرقمية التي يمكن تنميتها لطفل الروضة. 
وتأسيسًأ على ما سبق من مبادئ تم إعداد الوحدة المقترحة وفقًا للخطوات الاتية:

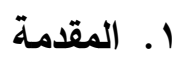

اشتملت المقدمة على الهدف من الوحدة وأهمية وضرورة تدريس مفاهيم مهارات المواطنة الرقمية لطفل الروضة، وعرض عام لكيفية تدريس الوحدة لطفل الروضة، والاستراتيجيات المستخدمة وخطوات السير في تقديم النشاط للطفل.

$$
\text { أوَلاً: الهدف العداف الوحدة: }
$$

تتمية بعض مفاهيم ومهارات المواطنة الرقمية لدى طفل الروضة. ثانيًا: الأهداف الإجرائية للوحدة: تتحدد الأهداف الإجرائية للوحدة المقترحة فيما يأتي: ا. يستخدم الإنترنت في الاتصال بأفراد المجتمع الافتراضي في المناسبات المختلفة

r. يقدر دور الإنترنت في الاتصال بأفراد المجتمع الافتراضي في المناسبات المختلفة. ז. يحترم خصوصية الآخرين عند استخدام التكنولوجيا والإنترنت. ع. يستخدم الإنترنت في البحث عن المعرفة. ه. يقدر أهمية استخدام الإنترنت في البحث عن المعرفة. 7. يتعرف على قواعد التجول الآمن على الإنترنت. V . يتعرف على معني البصمة الإلكترونية. ^. يقدر أهمية المحافظة على تكوين بصمة رقمية إيجابية له عند استخدام الإنترنت. 9. يهتم بوجود برامج حماية من الفيروسات على الأجهزة التي يستعملها. • ا.يحدد الأوقات المناسبة لاستخدام الألعاب الإلكترونية.

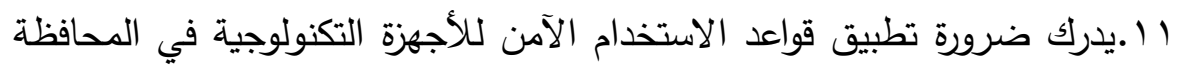




$$
\text { مجلة " دراسات في الطفولة والتربية" - جامعة اسيوط }
$$

$$
\begin{aligned}
& \text { على صحته. } \\
& \text { r ا.يتعرف على مهارات البيع والشراء من خلال الإنترنت. } \\
& \text { r. الخطة الزمنية لتدريس وحدة المواطنة الرقمية: }
\end{aligned}
$$

تم تدريس وحدة المواطنة الرقمية على مدار ( 0 ) أسابيع بواقع يومين في

الأسبوع، نشاطين في الأسبوع ومدة النشاط ـ ـ دقيقة. على النحو الآتي:

جدول (1): الخطة الزمنية لتدريس وحدة المواطنة الرقمية لطفل الروضة

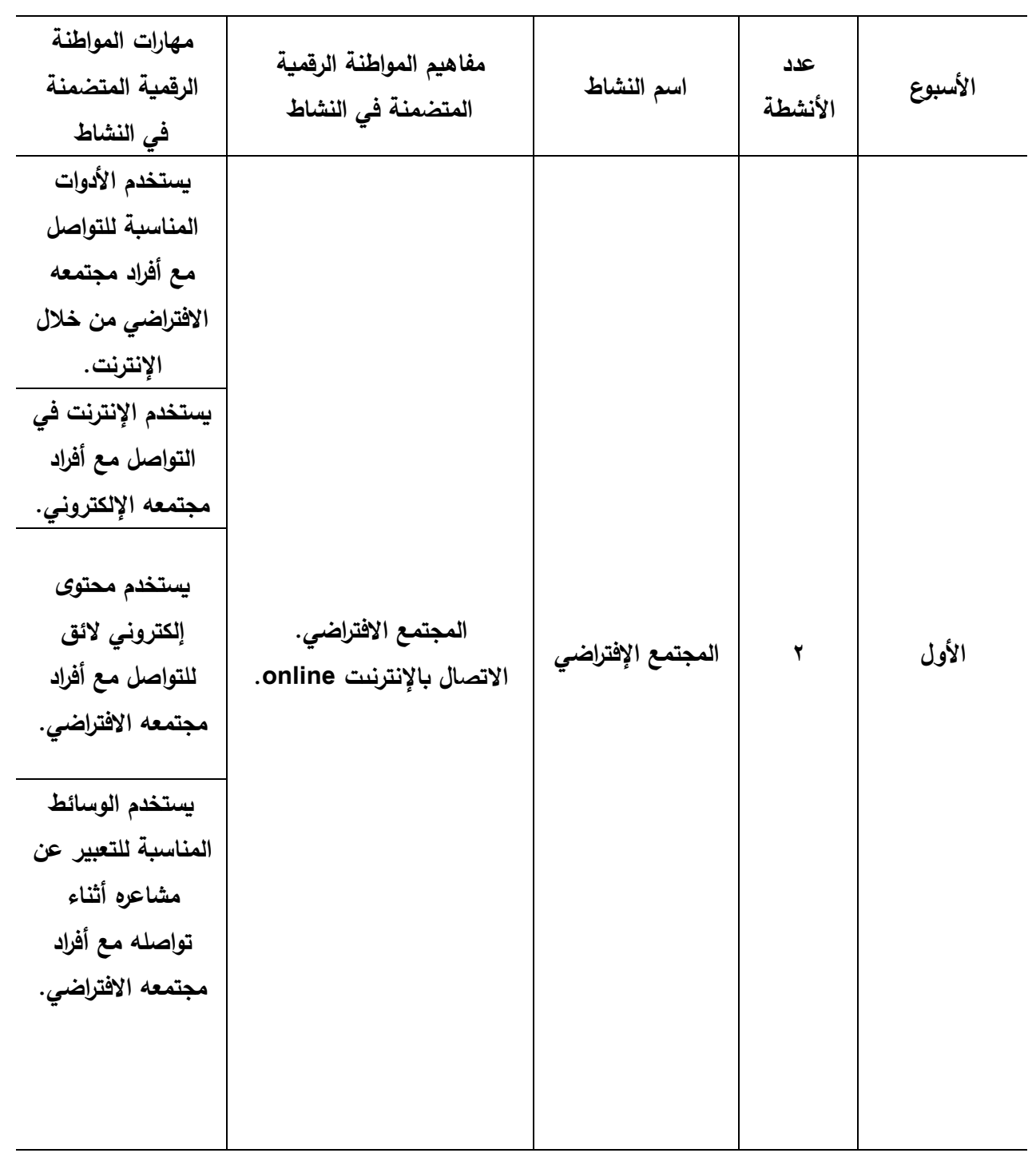


د.// هبة أحمد أحمد البنا

فاعلية وحدة مقترحة لتنمية بعض مفاهيم

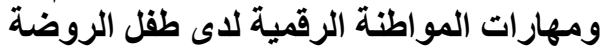

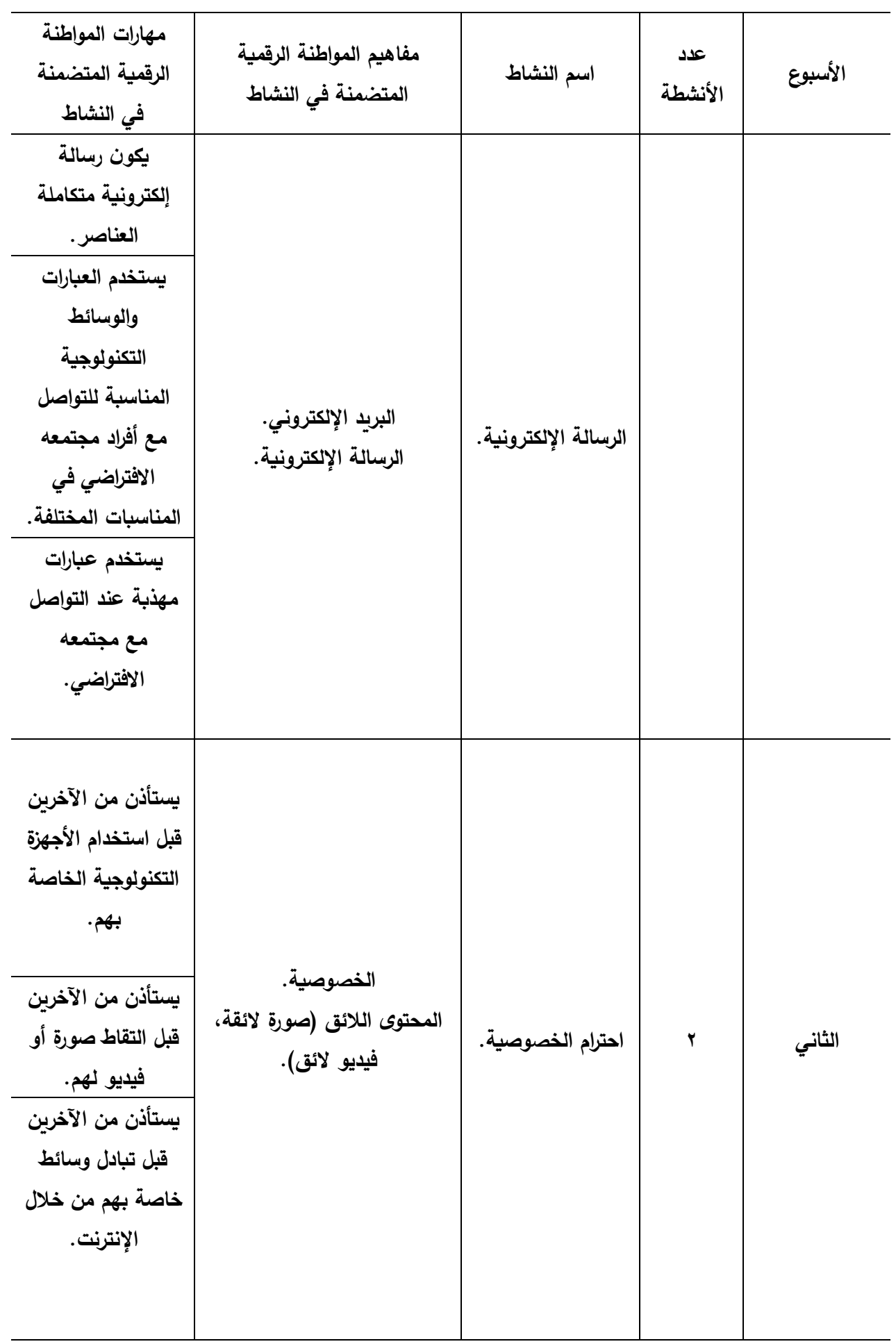


مجلة " دراسات في الطفولة والتربية" - جامعة اسيوط

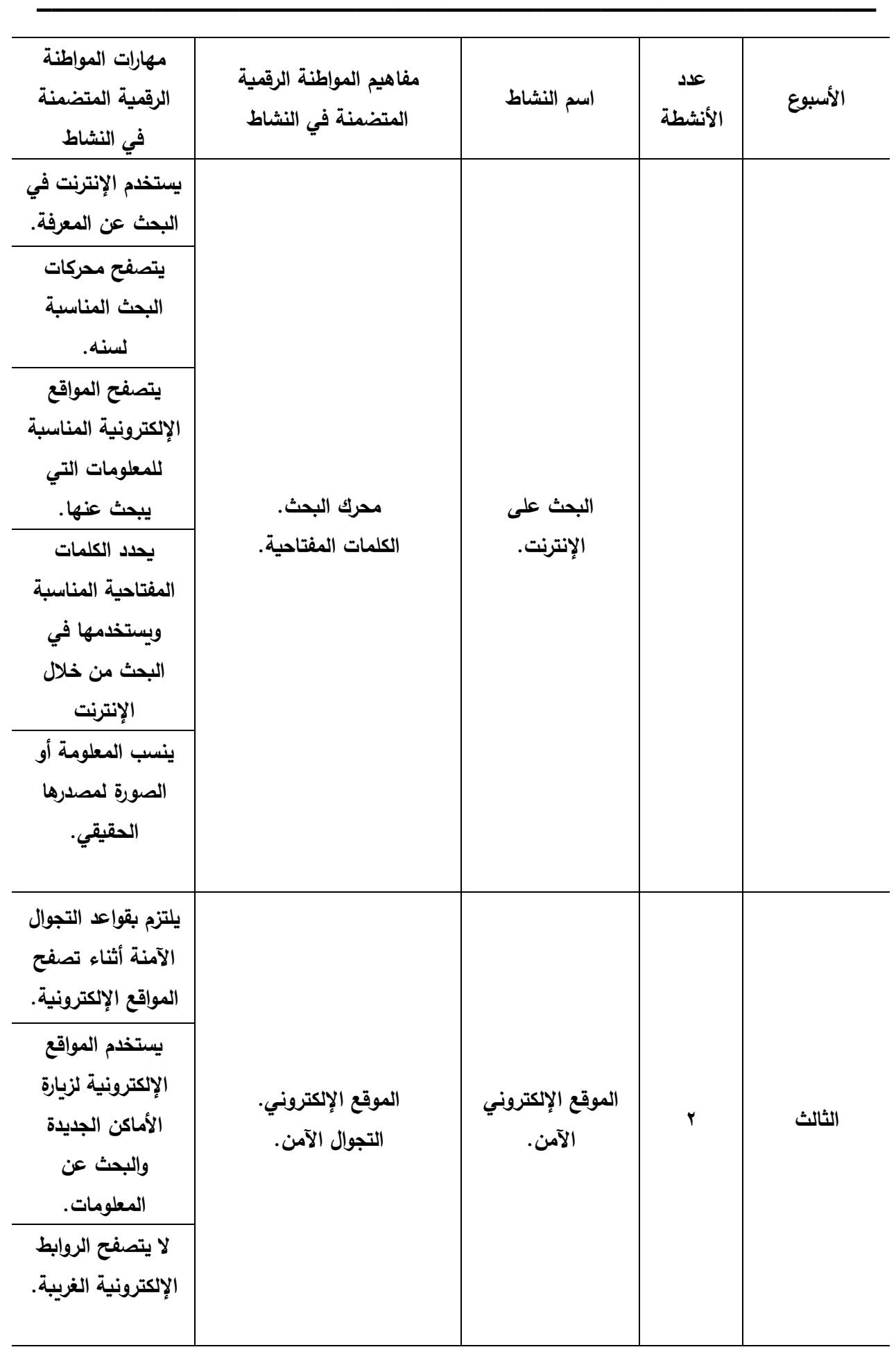


د.// هبة أحمد أحمد البنا

فاعلية وحدة مقترحة لتنمية بعض مفاهيم

ومهارات المواطنة الرقمية لاى طقل الروضة بعضة مفيمة

\begin{tabular}{|c|c|c|c|c|}
\hline فهارات المواطنة & مفاهيم المواطنة الرقمية & اسم النشاط & الأنثطة & الأسبوع \\
\hline 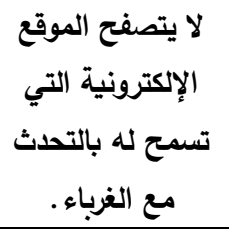 & & & & \\
\hline لا لا يتصفح الرسائل & & & & \\
\hline رقية إفظ على بصمة & \multirow{3}{*}{ البصمة الرقمية. } & \multirow{3}{*}{ البصمة الرقمية } & & \\
\hline تعطي الإكترونية التي المواقع & & & & \\
\hline البالغين عندما يجد مساعدة & & & & \\
\hline بتامقق من وجود الفيروسات ضد & برنامج الحماية من الفيروسات. & برامج الحماية من & \multirow{2}{*}{ r } & \multirow{2}{*}{ الرابع } \\
\hline الألأكترونية فيتخدم الألعاب & 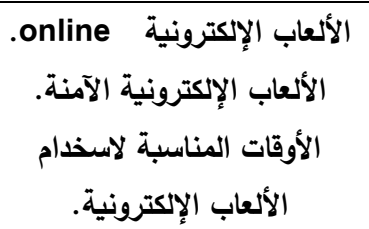 & الألعاب الإكترونية. & & \\
\hline
\end{tabular}




$$
\text { مجلة " دراسات في الطفولة والتربية" - جامعة اسيوط }
$$

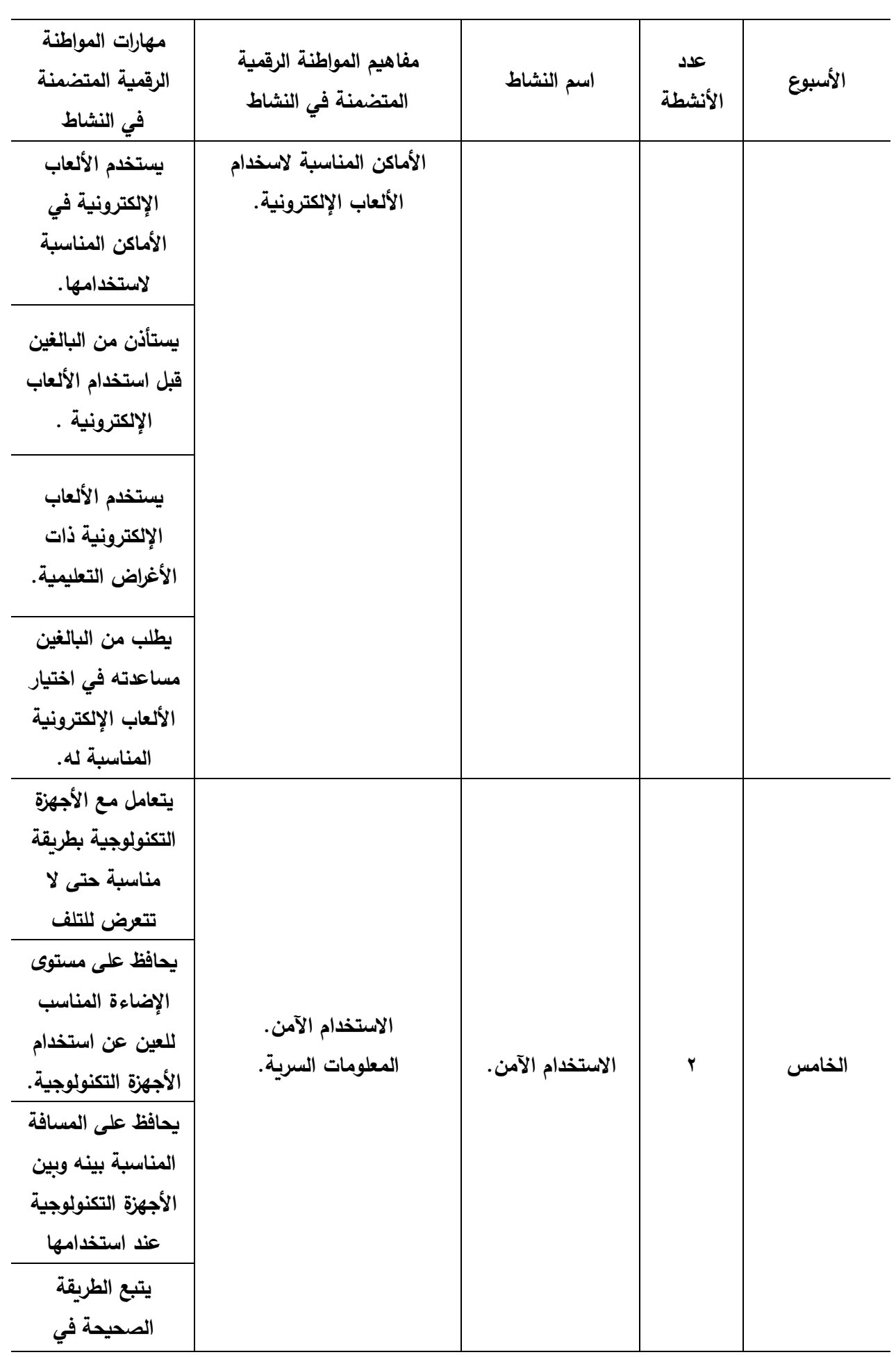


د.// هبة أحمد أحمد البنا

فاعلية وحدة مقترحة لتنمية بعض مفاهيم

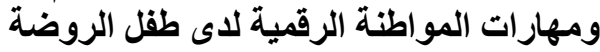

\begin{tabular}{|c|c|c|c|c|}
\hline الرقمية المتضمنة المواطنة & مفاهيم المواطنة الرقمية & اسم النثاط & الأنثطة & الأسبوع \\
\hline الجتخدام الأجهزة أثناء & & & & \\
\hline لا التكنولوجية أثناء الأجهزة & & & & \\
\hline التستخلم الأجهزة & & & & \\
\hline بحافظ على سرية البيانات الخاصة & \multirow{3}{*}{ النقود الإكترونية (بطاقة الإلكتروني. } & \multirow{3}{*}{ البيع والثراء على } & & \\
\hline 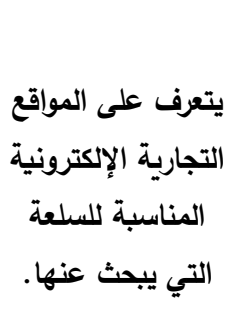 & & & & \\
\hline التجيز بين المواقع & & & & \\
\hline
\end{tabular}

العدد السابع عشر - أبريل r.r. 


$$
\text { مجلة " دراسات في الطفولة والتربية" - جامعة اسيوط }
$$

\begin{tabular}{|c|c|c|c|c|}
\hline مهارات المواطنة & مفاهيم المواطنة الرقمية & اسم النشاط & الأنثطة عدد & الأسبوع \\
\hline التواقع الإلكترونية المواقع & & & & \\
\hline \multicolumn{4}{|c|}{ ـ 1 أنشطة } & المجموع \\
\hline
\end{tabular}

\section{ع. محتوى وحدة المواطنة الرقمية}

اشتملت وحدة المواطنة الرقمية المقترحة على • ا أنشطة وكل نشاط احتوى على

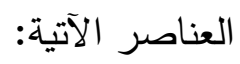

اشتمل كل نشاط من الأنشطة المقترحة على العناصر الآتية:

اسم النشاط: حرصت الباحثة على اختيار اسم مشوق يجذب انتباه الأطفال لكل نشاط من الأنشطة،وملائم لمحتوى النشاط.

الأهداف الإجرائية: تم صياغة أهداف كل نشاط في صورة إجرائية بحيث يسهل تحديد المطلوب منها في كل نثاط بثكل محدد وواضح.

مدة النشاط: تم الإثارة في كل نشاط إلى المدة المستغرقة له، مع الحرص ألا تكون طويلة جدا حتي لا يشعر الطفل بالملل. الأدوات والوسائل المستخدمة: تم توفير جميع الأدوات والوسائل المساعدة لكل

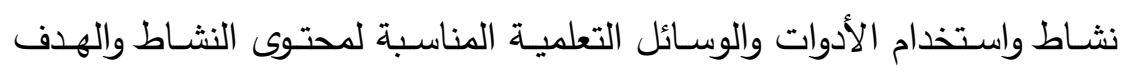
منه، وكذلك تثجيع الأطفال على المشاركة أثناء تنفيذ الأنثطة . الاسـتراتيجية: اعتمـدت الأنشطة المقترحـة على استخدام استراتيجيات متتوعـة مثل: الحوار والمناقثة، والعصف الذهني، والقصة، والدراما، وتتوعت الأنثطة 
بين أنشطة فنية، وقصصية، ودراما إبداعية.

مفـاهيم ومهـارات المواطنـة الرقميـة: تضـمن كل نشـاط مجموعـة مـن مفـاهيم

$$
\text { ومهارات المواطنة الرقمية التي تم تحديدها'. }
$$

خطوات سـير النشـاط: حرصــ الباحثة على أن يتضــن كل نشـاط الخطـوات التفصيلية لتنفيذه بشكل واضـح، مـع الحرص على أن يبدأ النشاط بالتهيئة والإثارة من خـلال سؤال مشـوق يثير فضـول الأطفـال أو روايـة قصـة قصسيرة عليهم أو عرض بطاقات مصورة ، ثم بعد التأكد من تهيئة الأطفال بصورة جيدة يتم عرض

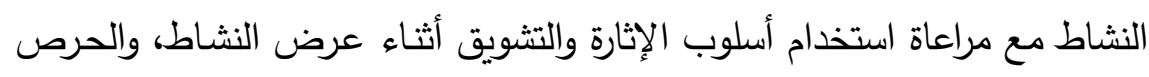
على مشـاركة الأطفال في النشـاط، وتثـيعهم على التفاعل والحـوار أثناء تقديم النشاط

التقويم: يتضـمن كل نشـاط عدد مـن أوراق العمل والمهام التي تشـمل تدريب

$$
\text { الأطفال على مفاهيم ومهارات المواطنة الرقمية. }
$$

\section{0. ضبط وحدة المواطنة الرقمية:}

بعد أن انتهت الباحثة من إعداد الوحدة المقترحة تم عرضها على مجموعة

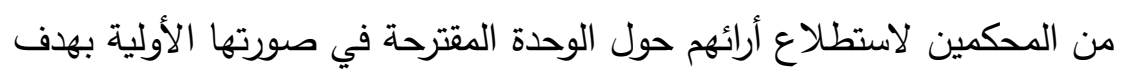

$$
\text { التحقق من صلاحيتها من حيث: }
$$

- مناسبة الأنشطة المقترحة للأطفال في مرحلة رياض الأطفال.

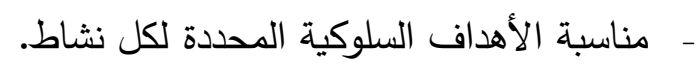

- ملائمة إجراءات الأنثطة مع المفاهيم والمهارات المتضدنة في الوحدة.

- مناسبة أوراق العمل المصاحبة لكل نشاط.

- تم عمل التعديلات التي أبداها السادة المحكمون، وبذلك أصبحت الوحدة

$$
\text { في صورتها النهائية؛ }
$$

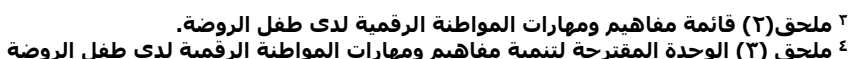




\section{مجلة " دراسات في الطفولة والتربية" - جامعة اسيوط}

\section{إعداد اختبار مفاهيم المواطنة الرقمية المصور لطفل الروضة}

للإجابة على السؤال الثالث من أسئلة الدراسة وهو: "ما فاعلية الوحدة المقترحة في تتمية بعض مفاهيم المواطنة الرقمية لدى طفل الروضة؟" قامت الباحثة بإعداد

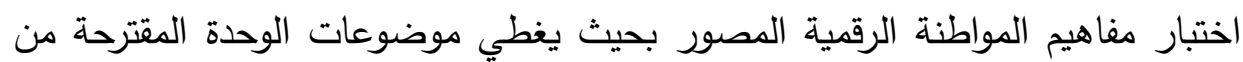

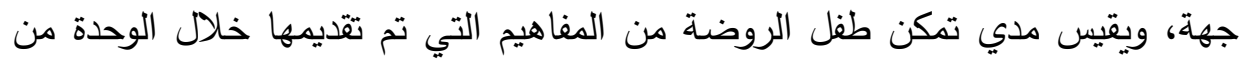
جهة أخرى، وذلك كأداة لقياس التغير في تحصيل مفاهيم المواطنة الرقمية نتيجة لتأثير العامل التجريبي، وهو تدريس الوحدة المقترحة في المواطنة الرقمية.

وقد مرت عملية بناء اختبار مفاهيم المواطنة الرقمية المصور للوحدة المقترحة

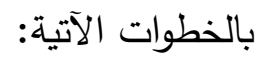

ا.تحديد الهدف من الاختبار : كان الهدف من الاختبار هو قياس مدي تحصيل طفل الروضة لمفاهيم المواطنة الرقمية المتضمنة في الوحدة المقترحة، وذلك ملك بتطبيقه قبليًا، ثم بعديًا على الأطفال مجموعة الدراسة.

r.صياغة مفردات الاختبار في صورتها الأولية: تم صياغة مفردات الاختبار

بحيث تغطي جميع مفاهيم المواطنة الرقمية المتضمنة في الوحدة، وقد روعي فيها أن تكون مناسبة لمستوى الأطفال، وأن تكون واضحة وسليمة وأن تتلاءم مع تحتويه الأنثطة من مفاهيم.

r. وقد تم بناء الاختبار بحيث يتضمن أربع محاور رئيسية ويشتمل كل محور على عدد من المفاهيم المتضمنة في كل نشاط، حيث بلغ عدد مفردات الاختبار

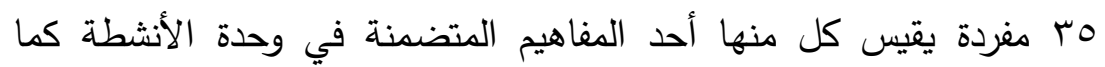

$$
\text { يظهر في الجدول (r): }
$$


د.// هبة أحمد أحمد البنا

فاعلية وحدة مقترحة لتنمية بعض مفاهيم

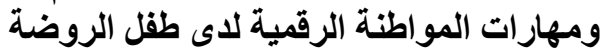

جدول( r ) جدول مواصفات اختبار مفاهيم المواطنة الرقمية المصور لدى طفل الروضة

\begin{tabular}{|c|c|c|c|c|}
\hline رقم المفردات & الدرجة & المفردات & مفاهيم المواطنة الرقمية & المحاور الرئيسية للاختبار \\
\hline \multirow{6}{*}{$(9-1)$} & \multirow{6}{*}{$q$} & \multirow{6}{*}{9} & المجتمع الافتراضي. & \multirow{6}{*}{ وآولاً: الاتصال بالآخرين التعامل معهم. } \\
\hline & & & الاتصال بالإنترنت online. & \\
\hline & & & البريد الإلكتروني. & \\
\hline & & & الرسالة الإكترونية. & \\
\hline & & & الخصوصية. & \\
\hline & & & المحتوى اللائق. & \\
\hline \multirow{8}{*}{$(19-1 \cdot)$} & \multirow{8}{*}{1.} & \multirow{8}{*}{1.} & محرك البحث. & \multirow{8}{*}{ والتصفيًا: البحث والمعرفة الإنترنت. } \\
\hline & & & البحث الصوتي. & \\
\hline & & & البحث بالصور . & \\
\hline & & & الرابط الإكتروني. & \\
\hline & & & الكلمات المفتاحية. & \\
\hline & & & التجوال الآمن. & \\
\hline & & & الموقع الإكتروني. & \\
\hline & & & الموقع الإكتروني الآمن. & \\
\hline \multirow{7}{*}{$(r V-r \cdot)$} & \multirow{7}{*}{$\wedge$} & \multirow{7}{*}{$\wedge$} & البصمة الرقمية. & \multirow{7}{*}{ ثالثًا: الأمان والخصوصية. } \\
\hline & & & المعلومات الخاطئة على & \\
\hline & & & الفيروس الإكتروني. & \\
\hline & & & برنامج الحماية من الفيروسات. & \\
\hline & & & النقود الإكترونية. & \\
\hline & & & الإعلان الإكتروني. & \\
\hline & & & المحل الإكتروني. & \\
\hline \multirow{3}{*}{$\left(r_{0}-Y_{\Lambda}\right)$} & \multirow{3}{*}{$\wedge$} & \multirow{3}{*}{$\wedge$} & الألعاب الإكترونية online. & \multirow{3}{*}{ رابعًا: الصحة والسلامة. } \\
\hline & & & الألعاب الإكترونية الآمنة . & \\
\hline & & & الأماكن المناسبة لاستخدام & \\
\hline
\end{tabular}

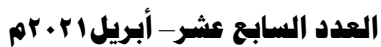




$$
\text { مجلة " دراسات في الطفولة وإلتربية" - جامعة اسيوط }
$$

\begin{tabular}{|c|c|c|c|c|}
\hline رقم المفردات & الارجة & المفردات & مفاهيم المواطنة الرقمية & المحاور الرئيسية للاختبار \\
\hline & & & الألعاب الإلكترونية. & \\
\hline & & & الأوقات المناسبة لاستخدام & \\
\hline & & & الاستخدام الآمن للتكنولوجيا. & \\
\hline & & & الاستخدام غير الآمن & \\
\hline \multicolumn{3}{|c|}{ ro } & \multicolumn{2}{|c|}{ المجموع } \\
\hline
\end{tabular}

ع. صياغة مفردات الاختبار : تم صياغة مفردات الاختبار بحيث يتكون من هب سؤالاً،

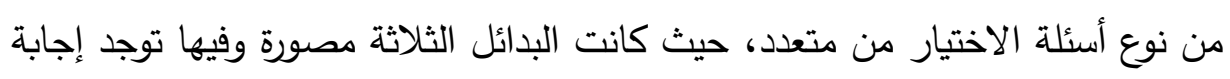

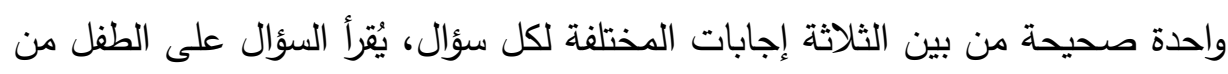
قبل الباحثة ويختار بين الثلاثة بدائل المصورة. ه. وضع تعليمات الاختبار: تم صياغة بعض التعليمات للاختبار وتضمنت هذه

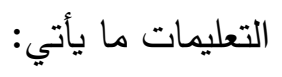
هيتم تطبيق الاختبار على الأطفال بشكل فردي. تُعرض مفردات الاختبار المصور على الطفل بصورة فردية واحدة تلو الأخرى. • تُقرأ العبارات اللفظية على الطفل بوضوح دون إيحاء للطفل بالإجابة

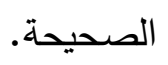
• يختار الطفل البديل الصحيح من بين البدائل الثلاثة بوضع علامة صح أو دائرة حول الإجابة التي يختارها. • في حالة اختيار الطفل للبديل المصور الصحيح يحصل على درجة واحدة. 
في حالة اختيار الطفل للبديل المصور الخطأ يحصل على درجة • صفر

تقدر درجات كل مفردة من مفردات الاختبار درجة واحدة بحيث يكون المجموع الكلي لدرجات الاختبار هـ درجة.

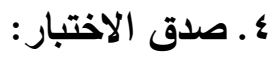

تم حساب صدق الاختبار من خلال عرض الاختبار على السادة المحكمين لإبداء آرائهم في الاختبار من حيث:

مدى مناسبة ووضوح مفردات الاختبار والصور لطفل الروضة (0-7) سنوات.

مدى مناسبة مفردات الاختبار والصور للمفهوم الذي وضعت لقياسه. مدى مناسبة المفردات من حيث الصياغة اللغوية بالنسبة لطفل

$$
\text { الروضة. }
$$

مدى سلامة تعليمات الاختبار •

وبناء على ملاحظات السادة المحكمين قامت الباحثة بإجراء بعض التعديلات

اللازمة مثل: حذف بعض الأسئلة، تعديل بعض الصور المستخدمة كبدائل لدفردات الاختبار، دمج بعض الأسئلة، تعديل صياغة بعض الأسئل، تعديل بعضئلة والعبارات.

جدول (ץ) أمثلة من الملاحظات التي أبداها السادة المحكمون على اختبار

\section{مفاهيم المواطنة الرقمية}

\begin{tabular}{|c|c|c|}
\hline بعد التعديل & قبل التعديل & الفقرة \\
\hline المجتمع الافتراضي. & المجتمع الإلكتروني. & فقرة 1 \\
\hline إذا أردت أن تلتقط صورة لزميك باستخدام الموبايل ماذا & أي من الصور الآتية يجب الاستئذان قبل التقاطها & فقرة \\
\hline $\begin{array}{c}\text { الرسالة الإلكترونية هي رسالة يمكن إرسالها للآخرين } \\
\text { باستخدام ....... }\end{array}$ & أي مما يأتي يعبر عن الرسالة الإلكترونية...... & فقرة V \\
\hline
\end{tabular}




$$
\text { مجلة " دراسات في الطفولة والتربية" - جامعة اسيوط }
$$

\begin{tabular}{|c|c|c|}
\hline بعد التعديل & قبل التعديل & الفقرة \\
\hline 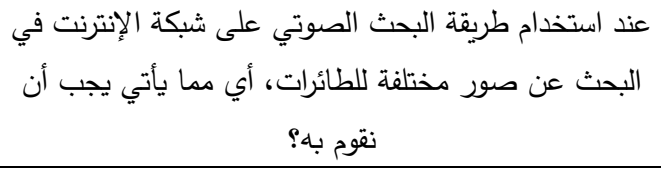 & 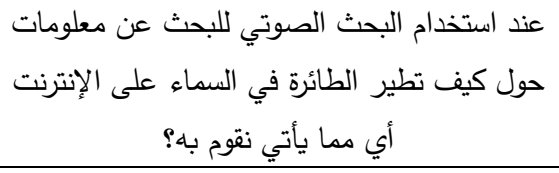 & 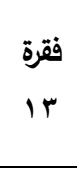 \\
\hline لمشاهدة فيديو على اليوتيوب عن رائد الفضاء وهو على القدر ، الكلمات المفتاحية التي ننطقها؟ & ما هي الكلمات المفتاحية التي ننطقها للبحث عن الصورة التالية من خلال البحث الصوتي؟ & فقرة \\
\hline
\end{tabular}

بعد إجراء التعديلات التي اقترحها السادة المحكمون، تم تجربة الاختبار استطلاعياً على مجموعة قوامها (· (1) أطفال من أطفال روضة (المساعي المشكورة

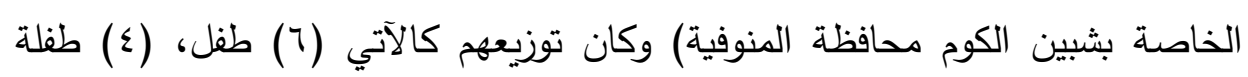

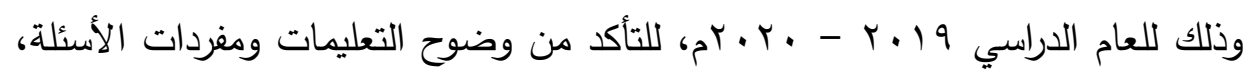
وحساب الزمن الذي يستغرقه تطبيق الاختبار، وتم تقدير الزمن اللازم للإجابة على وضى

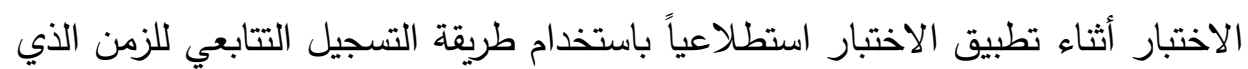

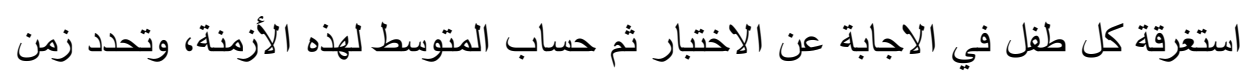
الإجابة على الاختبار بالتقريب بـ (• ع) دقيقة.

كما تم التحقق من صدق الاختبار باستخدام صدق الاتساق الداخلي حيث تم

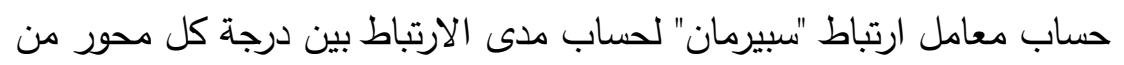

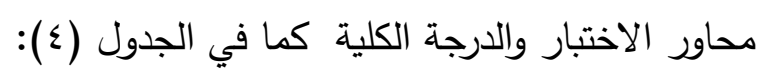
جدول ( \& ) معاملات الاتساق الداخلي لمحاور الاختبار

(معاملات ارتباط سبيرمان)

\begin{tabular}{|c|c|c|c|c|}
\hline محور \& & محور r & محور r & محور 1 & المحور \\
\hline$* *, v r$ & $* *, \vee \wedge$ & $* *, \vee \vee q$ & **, & بالاختبار ككل الارتباط \\
\hline
\end{tabular}

** دالة احصائيا عند مستوى 1 .,. 
ويتضح من الجدول السابق أن معاملات الإرتباط بين درجات كل بعد والدرجة

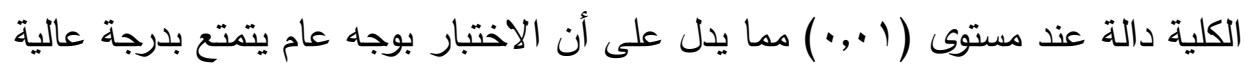
من الصدق وصادق لما وضع لقياسه.

\section{هـ ثبات الاختبار:}

تم حساب ثبات الاختبار باستخدام طريقة ألفا كرونباخ Alpha Crunbach في

حساب الثبات، حيث تم حساب ثبات الاختبار وحساب ثبات محاور الاختبار ، ووجد أن ثان ثرات

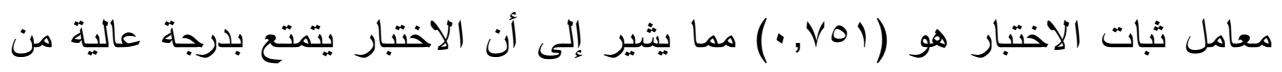

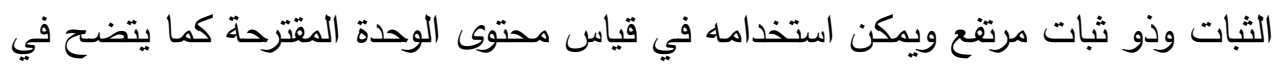

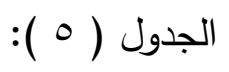

جدول رقم(ه) ثبات اختبار مفاهيم المواطنة الرقمية المصور بطريقة ألفا كرونباخ

\begin{tabular}{|c|c|c|c|c|c|}
\hline كلا & محور ؛ & محور & محور ז & محور 1 & المحور \\
\hline$\cdot, \mathrm{V} 01$ & •, VOF & - $\mathrm{V} 0 \mathrm{~T}$ & $\cdot, v \leqslant q$ & •, vo. & ألفا كرونباخ \\
\hline
\end{tabular}

كما تم التحقق من ثبات الاختبار بطريقة إعادة التطبيق حيث تم إعادة تطبيق

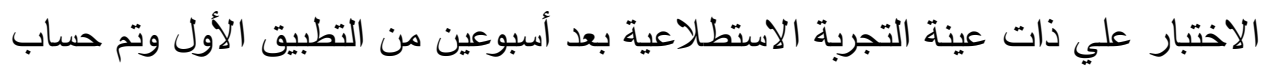

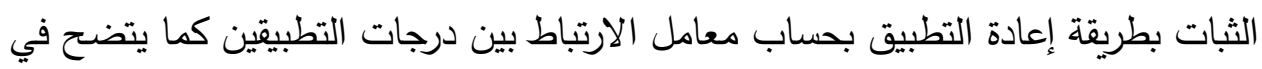

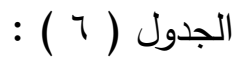

جدول رقم (؟) ثبات اختبار مفاهيم المواطنة الرقمية المصور بطريقة إعادة التطبيق.

\begin{tabular}{|c|c|c|c|c|c|}
\hline ار ككل & المحور ؛ & المحور & المحور ץ & المحور & المحور \\
\hline - Ar & $\cdot, \wedge \varepsilon$ & ., ו & ., $\vee$ q & • & معامل الارتباط \\
\hline
\end{tabular}




\section{مجلة " دراسات في الطفولة والتربية" - جامعة اسيوط}

وبذلك يتضح من الجدول السابق أن ألفا للاختبار ككل rم, · وهذا يثير إلى أن

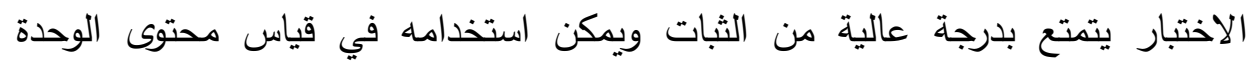

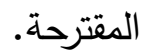

عقب الانتهاء من إجراءات ضبط الاختبار - كما سبق توضيحه - أصبح الاختبار في صورته النهائية عبارة عن (ب0) مفردة من نمط الاختيار من متعدد حيث

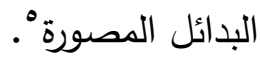

إعداد بطاقة ملاحظة بعض مهارات المواطنة الرقمية لطفل الروضة.

للإجابة عن السؤال الرابع من أسئلة الدراسة وهو : "ما فاعلية الوحدة المقترحة في تتمية بعض مهارات المواطنة الرقمية لدى طفل الروضة" قامت الباحثة بإعداد بطاقة ملاحظة لتقيس مدى تمكن طفل الروضة من أدداء المهارات التي تم تدريسها من خلال الوحدة المقترحة، وذلك كأداة لقياس التغير في مهارات المواطنة الرقمية، نتيجة لتأثير العامل التجريبي، وهو تدريس الوحدة المقترحة في المواطنة الرقمية، وقد مرت عملية بناء

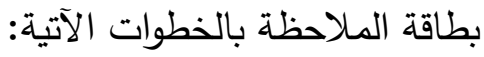

ا. تحديد الهدف من البطاقة: كان الهدف من البطاقة هو قياس مدى تمكن طفل الروضة من مهارات المواطنة الرقمية المتضمنة في الوحدة المقترحة، وذلك من منكان بتطبيقها قبليًا ثم بعديًا على الأطفال مجموعة الدراسة.

r. r.حديد المهارات المتضمنةج في الوحدة المقترحة التي تقيسها بطاقة الملاحظة. r.اعداد جدول المواصفات: تم إعداد البطاقة وفقًا لجدول المواصفات، جدول

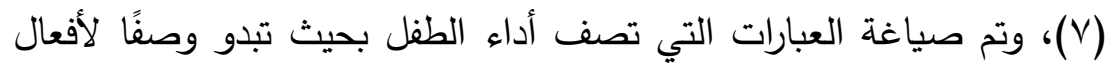
سلوكية واضحة ومحددة يسهل ملاحظتها.

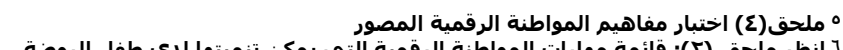


جدول (V) جدول مواصفات بطاقة ملاحظة مهارات المواطنة الرقمية

\begin{tabular}{|c|c|c|c|}
\hline النسبة المئوية & عدد البنود & المهارات الأساسية & b \\
\hline$\% r r, v$ & 1. & الاتصال بالآخرين وآداب التواصل معهم. & 1 \\
\hline$\%$ ro & 11 & البحث والمعرفة والتصفح عبر الإنترنت. & r \\
\hline$\%$ ro & 11 & الأمان والخصوصية. & $r$ \\
\hline$\% r v, r$ & ir & الصحة والسلامة. & $\varepsilon$ \\
\hline$\% 1 \ldots$ & $\varepsilon \varepsilon$ & 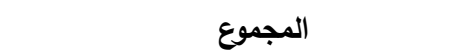 & \\
\hline
\end{tabular}

ا ـ التقدير الكمي لمهارات المواطنة الرقمية: تم تحديد التقدير الكمي لمهارات المواطنة الرقمية لطفل الروضة بثلاث مستويات (جيد وتقدر بدرجتين، ومتوسط وتقدر بدرجة، وضعيف وتقدر بصفر) وفقًا للتدرج الآتي:

• جيد: ويعني ظهور أداء الطفل للمهارة بشكل واضح وصريح ودائم

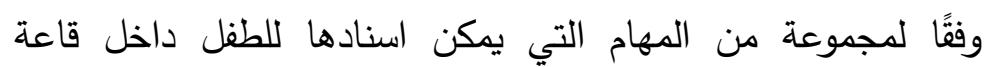

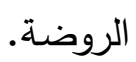

متوسط: ويعني ظهور أداء الطفل للمهارة بدرجة أقل وضوحًا وفقًا

لمجموعة من المهام التي يتم إسنادها للطفل داخل قاعة الروضة. ضعيف: ويعني ظهور أداء الطفل للمهارة بثكل قليل جدًا ونادر وفقًا لمجموعة من المهام التي يتم إسنادها للطفل داخل قاعة الروضة.

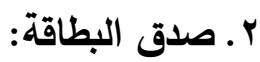

صدق المحكمين : تم عرض البطاقة علي مجموعة من السادة المحكمين وتم التعديل في ضوء آرائهم ، وتم اعتماد البنود التي تم الاتفاق عليها.

صدق الاتساق الداخلي: تم حساب معامل ارتباط "بيرسون" لحساب مدى الارتباط بين درجة كل مهارة والدرجة الكلية للبطاقة كما في الجدول ( 1 ): 


$$
\text { مجلة " دراسات في الطفولة والتربية" - جامعة اسيوط }
$$

جدول ( A ) صدق الاتساق الداخلي لبطاقة مهارات المواطنة الرقمية

\begin{tabular}{|c|c|c|c|c|}
\hline مهارة الصحة & مالخصوصية الأمان & مالبحث والتصفح المعرفة & بالآخرين وآداب التصال & المهارة \\
\hline r, & $\cdot, \wedge 9$ & $\cdot, 91$ & $\cdot, \wedge V$ & بالارجة الكلية \\
\hline
\end{tabular}

يتبين من الجدول ( 1 ) أن جميع معاملات الارتباط جاءت دالة إحصائيًا مما

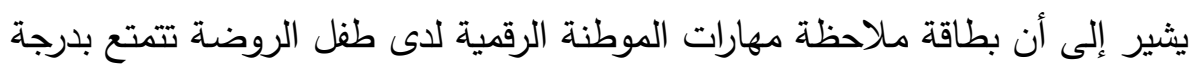
كبيرة من الاتساق الداخلي وصالحة للتطبيق.

r.ثبات البطاقة: تم حساب معامل ثبات البطاقة من خلال استخدام "معامل

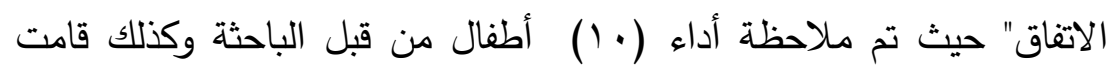
إحدي الزميلات بملاحظة أداء نفس الأطفال وتم تسجيل الملاحظات حول بنود ومؤشرات الأداء للمهارات الفرعية والرئيسية للبطاقة ككل وتم حساب نسبة الإنة الاتفاق بين الملاحظين ويوضح الجدول التالي نسبة اتفاق الملاحظين على

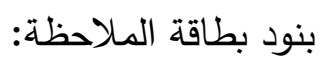
جدول (9) نسبة الاتفاق بين الملاحظين

\begin{tabular}{|c|c|c|}
\hline نسبة الاتفاق\% & عدد المؤشرات الفرعية & المهارة \\
\hline$\% 90$ & 1. & الاتصال بالآخرين وآداب التعامل \\
\hline$\% \wedge$ & 11 & البحث والمعرفة والتصفح عبر \\
\hline$\% 9$. & 11 & الأمان والخصوصية. \\
\hline$\% \wedge$ & ir & الصحة والسلامة. \\
\hline$\% \wedge \vee, 0$ & $\varepsilon \varepsilon$ & البطاقة ككل. \\
\hline
\end{tabular}

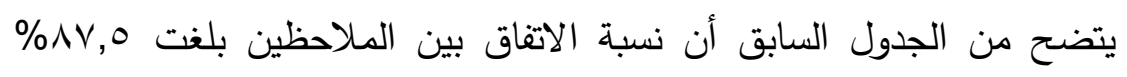
وهي نسبة مرتفعة تثير الي ثبات البطاقة وصلاحيتها للتطبيق. 
كما تم حساب الثبات بطريقة ألفا كرونباخ، وبلغ معامل الثبات للبطاقة ككل=

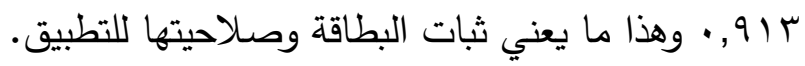

ع. بالانتهاء من ضبط بطاقة الملاحظة أصبحت البطاقة في صورتها النهائية v وجاهزة للتطبيق.

\section{تنفيذ تجربة الدراسة}

تم تنفيذ التجربة الأساسية للدراسة وفقاً للخطوات الآتية: 1. اختيار عينة الدراسة من أطفال رياض الأطفال بمدرسة الثهيد عبد الرحمن الايب التابعة لإدارة شبين الكوم التعليمية، بطريقة مقصودة.

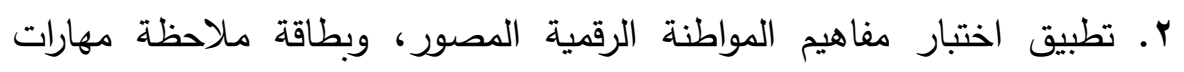

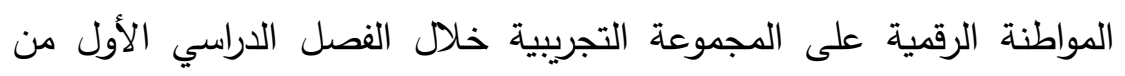

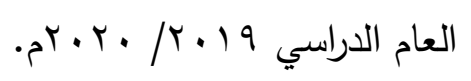

r. تقديم أنشطة الوحدة المقترحة لأطفال التجربة الأساسية خلال الفصل الفصل الدراسي

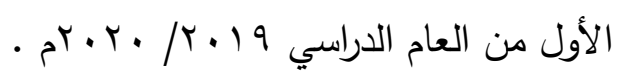

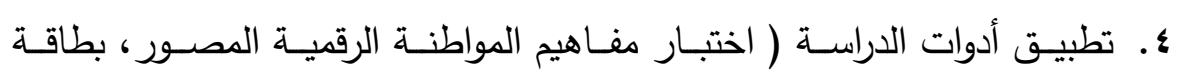
ملاحظة مهارات المواطنة الرقمية) بعدياً، بعد تقديم أنثطة الوحدة المقترحة.

\section{نتائج الاراسة ومناقشتها وتفسيرها}

يهدف هذا الجزء لتحليل النتائج النهائية التي أسفر عنها تطبيق اختبار مفاهيم المواطنة الرقمية المصور وبطاقة ملاحظة مهارات المواطنة الرقمية لطفل الروضة، والتحقق من صحة فروض الدراسة، وتفسير النتائج، وذلك بهدف التعرف علي فاعلية وحدة مقترحة لتتمية بعض مفاهيم ومهارات المواطنة الرقمية لدى طفل الروضة من خلال قياس فاعلية

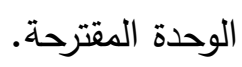




\section{مجلة " دراسات في الطفولة والتربية" - جامعة اسيوط}

•وللتحليل الاحصائي لبيانات البحث استخدمت الباحثة الرزمة الإحصائية للعلوم

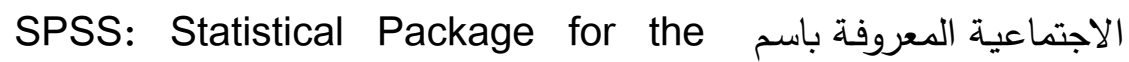

Social Sciences v.25

•وتم الاعتماد علي حساب الأساليب الاحصائية الوصفية (المتوسط الحسابي ، الانحراف المعياري ، أكبر درجة ، أصغر درجة الأدال

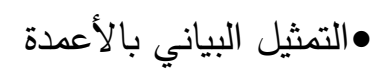

•التحليل الاحصائي التأكيدي بحساب اختبار (ت) للمجموعتين المترابطتين. •اختبار مربع ايتا وحجم الأثر لبحث الفعالية.

•نسبة الاتفاق ، ألفا كرونباخ للثبات ، معاملات الارتباط بيرسون لدراسة صدق

$$
\text { اختبار صحة الفروض* الاتساق الداخلي. }
$$

اختبار صحة الفرض الأول : " توجد فرق دال إحصائيا عند مستوى الدلالة

(1., · ) بين متوسطي درجات التطبيقين القبلي والبعدي لاختبار مفاهيم المواطنة

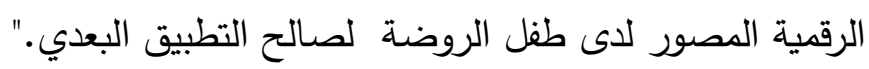

ولاختبار صحة هذا الفرض تم وصف وتلخيص بيانات البحث بحساب (المتوسط الحسابي، الانحراف المعياري، أكبر درجة، أصغر درجة) لدرجات عينة البحث

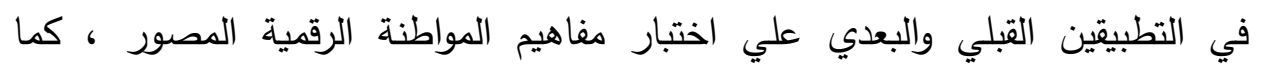
يوضحها الجدول التالي (جدول • (1):

SPSS : Statistical Package for the Social Sciences : استخدمت الباحثة الرزمة الإحصائية للعلوم الاحتماعية المعروفة باسـم * 
جدول (• 1 ) الإحصاءات الوصفية لارجات عينة البحث في التطبيقين علي اختبار مهارات المواطنة الرقمية المصور.

\begin{tabular}{|c|c|c|c|c|c|c|c|}
\hline العظمي & درجة & أصغر & الانعراف & المستوسط & 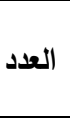 & التطبيقين & المحور \\
\hline \multirow[t]{2}{*}{9} & 9 & $\wedge$ & $\cdot, r \wedge$ & $\wedge, \wedge r$ & r. & البعدي & \multirow{2}{*}{ وآداب التعالمل معقهم } \\
\hline & 9 & r & $r, \cdot 9$ & אוד, או & $r$. & القبلي & \\
\hline \multirow{2}{*}{1.} & 1. & V & $\cdot, \vee \wedge$ & 9,04 & r. & البعدي & \multirow{2}{*}{ البحث والمعرفة } \\
\hline & $\wedge$ & 1 & $1, v$. & $r, r v$ & $r$. & القبلي & \\
\hline \multirow[t]{2}{*}{$\wedge$} & $\wedge$ & V & $\cdot$, ऍ & $\vee, \wedge r$ & $r$. & البعدي & \multirow{2}{*}{ الأمان والخصوصية } \\
\hline & $\wedge$ & 1 & $1, \times 1$ & $r, T V$ & $r \cdot$ & القبلي & \\
\hline \multirow[t]{2}{*}{$\wedge$} & $\wedge$ & V & $\cdot, r$ & $\vee, q$. & r. & البعدي & \multirow{2}{*}{ الصحة والسلامة } \\
\hline & $\wedge$ & 1 & $1,7 \varepsilon$ & r,r. & $r$. & القبلي & \\
\hline \multirow{2}{*}{ ro } & ro & r t & $\cdot, 99$ & $r \varepsilon, 1$. & $r$. & البعدي & \multirow{2}{*}{ المواطنة الرقمية مفاهيم } \\
\hline & rt & 7 & 0,09 & $M, \wedge V$ & r. & القبلي & \\
\hline
\end{tabular}

يتضح من الجدول أعلاه أن متوسط درجات التطبيق البعدي علي اختبار مفاهيم

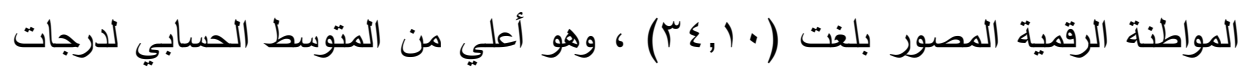

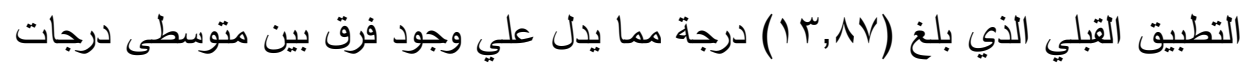

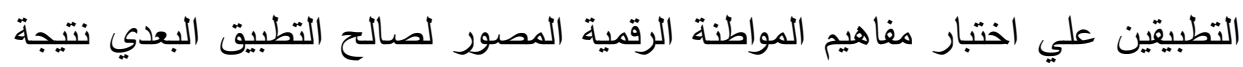
تعرضهم للمعالجة التجريبية (الوحدة المقترحة). وبتمثيل درجات مجموعتي البحث باستخدام شكل الأعمدة البيانية اتضح ما يلي في شكل (1): (1) - (1) 


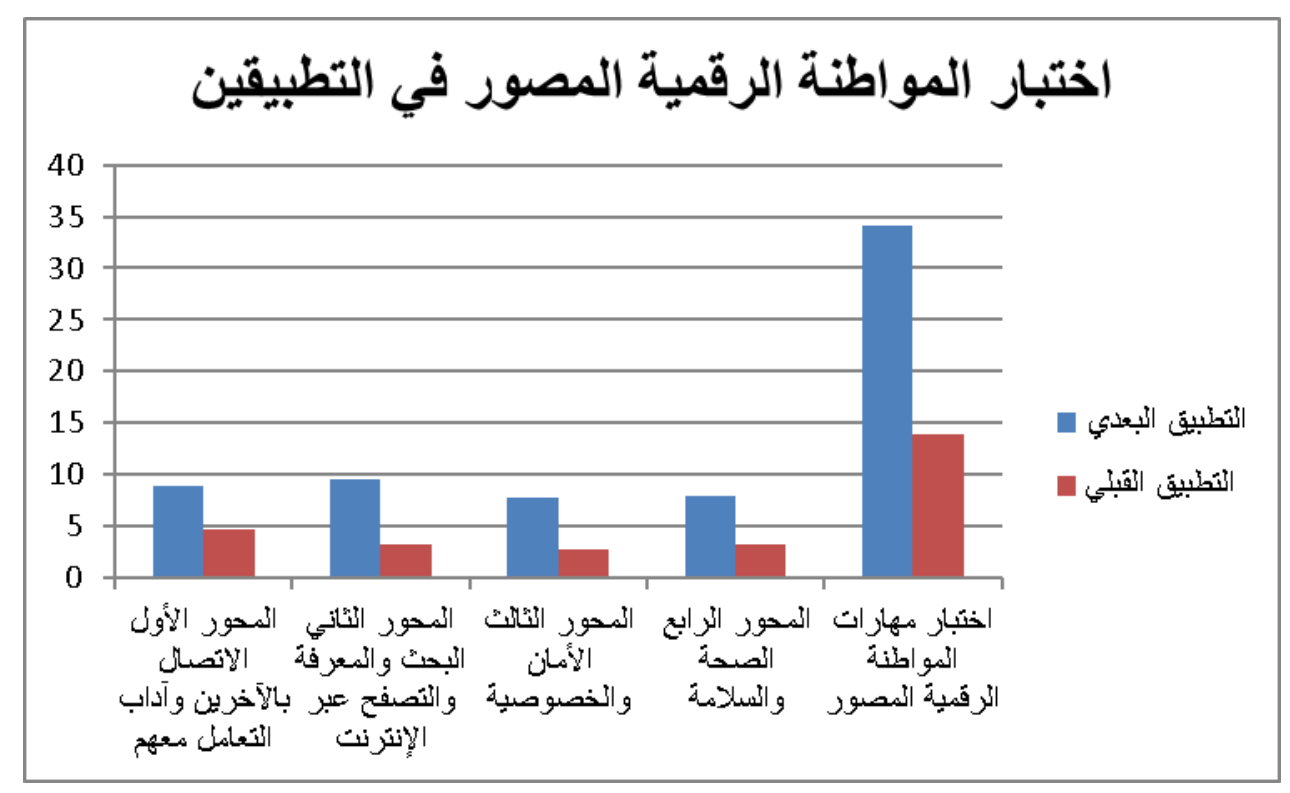

\section{شكل ( 1 ) التمثيل البياني بالأعمدة لمتوسطات درجات التطبيقين}

ويتضح من التمثيل البياني السابق وجود فروق واضحة بيانيا بين درجات التطبيقين علي اختبار مفاهيم المواطنة الرقمية المصور ـ وللتحقق من الدلالة الإحصائية للفرق بين المتوسطين تم استخدام اختبار ( ت) للمجموعتين المرتبطتين (مجموعة واحدة تطبيق متكرر)، وبتطبيق اختبار( (ت) لفرق المتوسطين لقياس مقدار دلالة الفرق بين متوسطى درجات التطبيقين اتضح ما يلى: ولطيق احتران

جدول ( 11 ) نتائج اختبار " ت " للفرق بين متوسطي درجات التطبيقين في

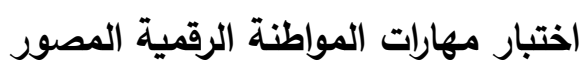

\begin{tabular}{|c|c|c|c|c|c|}
\hline مستوي الدلالة & الدرية & قيمة ت & للفرعياري & المتوسطين & المحور \\
\hline مستوي | +,. & rq & 11,11 & $r, .4$ & $\varepsilon, r$. & الاتصال بالآخرين وآداب \\
\hline مستوي ا +,. & rq & $17, \wedge 1$ & $r, \cdot r$ & $7, r V$ & البحث والمعرفة والتصفح \\
\hline
\end{tabular}




\begin{tabular}{|c|c|c|c|c|c|}
\hline مستوي الدلالة & الحرية & قيمة ت & اللفعرياري اللمراف & المتوسطين & المحور \\
\hline مستوي ا +,. & rq & $|7, \wedge|$ & 1,71 & $0,1 \mathrm{~V}$ & الأمان والخصوصية \\
\hline مستوي ا.,. & rq & $10, .7$ & $1,7 V$ & $\varepsilon, 7$. & الصحة والسلامة \\
\hline مستوي ا +,. & rq & 19,41 & $0, V \leqslant$ & $r \cdot, r r$ & اختبار مفاهيم المواطنة \\
\hline
\end{tabular}

يتضح من الجدول السابق أن قيمة " ت " المحسوبة (19,r)

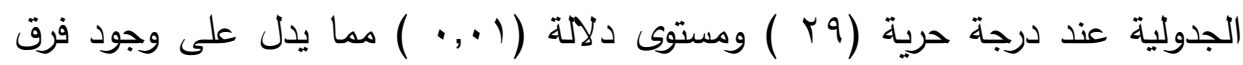

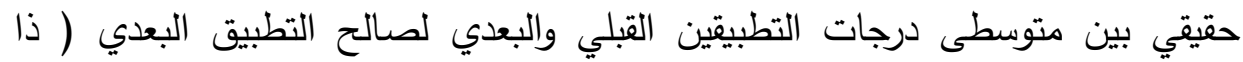

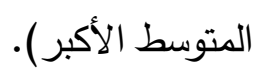

وبالتالي تم قبول الفرض الذي ينص على وجود فرق دال إحصائيا عند مستوى

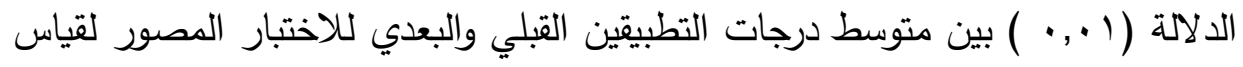
مفاهيم المواطنة الرقمية لدى طفل الروضة لصنالح التطبيق البعدي."

ويتقق ما توصلت إليه الدراسة الحالية مع نتائج الدراسات السابقة التي أكدت على التى فاعلية البرامج و المناهج التعليمية في تتمية مفاهيم المواطنة الرقمية لدى المتعلمين

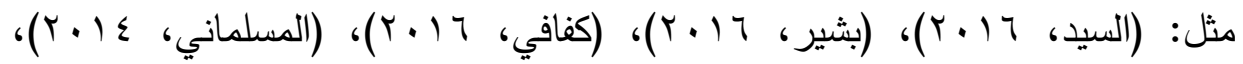

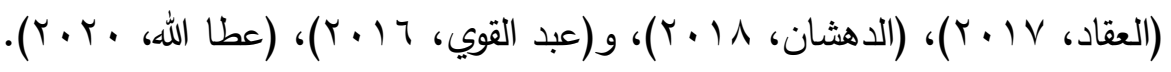

ويمكن إرجاع فاعلية الوحدة المقترحة في تتمية بعض مفاهيم المواطنة الرقمية

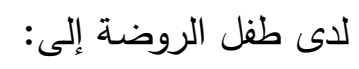

التــوع في الأنثـطة التـي تتضــنها الوحـدة لتقـديم مفـاهيم المواطنـة الرقميـة

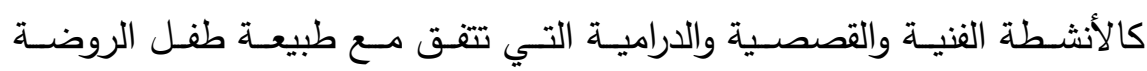
وخصائص نموه، وتثجعه على المشاركة والإيجابية في عملية التعلم.

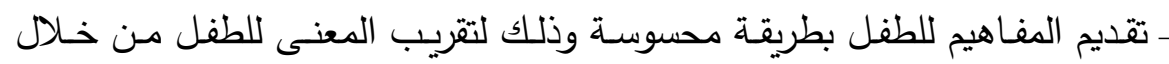
استخدام وسائل تعليمية متتوعة كاللوحة الوبريـة في نشاط (البصمة الرقمية) الذي ولي تتـاول مفهوم (البصـمة الرقميـة)، واستخدام القصـة المصـورة في نشـاط (الموقـع 


\section{مجلة " دراسات في الطفولة والتربية" - جامعة اسيوط}

الإلكتروني الآمن) لتقديم مفاهيم (الموقع الإلكتروني والتجوال الآمن)، والبطاقات المصورة في نشاط (الألعاب الإلكترونية) لتقديم مفاهيم الألعاب الإلكترونية الآمنة الإنية

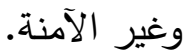

ــ تقديم المفاهيم من خلال استخدام استراتيجات التعلم النشط كاستراتيجية العصف العف الذهني والحوار والمناقثـة لتقديم مفهوم (الخصوصية ومفهوم المحتوى اللائق) ، واستراتيجية لعب الدور لتقديم مفهوم (البريد الإكترونسي والرسـالة الإلكترونيـة، والنقود الإلكترونية، والإعلان الإككتروني). اختبار صحة الفرض الثاني : " توجد فرق دال إحصائيا عند مستوى الدلالة (1 ., ) ) بين متوسطي درجات التطبيقين القبلي والبعدي لبطاقة ملاحظة مهارات المواطنة الرقمية لدى طفل الروضة

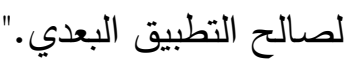

ولاختبار صحة هذا الفرض تم وصف وتلخيص بيانات البحث بحساب (المتوسط الحسابي، الانحراف المعياري، أكبر درجة، أصغر درجة) لدرجات عينة البحث في التطبيقين القبلي والبعدي علي بطاقة ملاحظة مهارات المواطنة الرقمية ، كما يوضحها لاجها

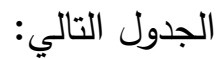

جدول( r r ) الإحصاءات الوصفية لارجات عينة البحث في التطبيقين علي بطاقة ملاحظة مهارات المواطنة الرقمية.

\begin{tabular}{|c|c|c|c|c|c|c|c|}
\hline العظمي & درجة & أصغر & الانحراف & المسابي & العدد العد & التطبيقين & المهارة \\
\hline \multirow{2}{*}{ r. } & $r$. & iv & $\cdot, 71$ & $19, \wedge$ & $r$. & البعدي & \multirow{2}{*}{ وآداب التعامل معهم بالآخرين } \\
\hline & ir & 1 & $r, 04$ & $\uparrow, \wedge$ & $r \cdot$ & القبلي & \\
\hline \multirow[b]{2}{*}{ rY } & rt & 19 & $\cdot, \mathrm{V} \vee$ & YI,OV & $r$. & البعدي & \multirow{2}{*}{ البحث والمعرفة } \\
\hline & 11 & 1 & 1,99 & $1, \wedge$ & $r \cdot$ & القبلي & \\
\hline \multirow{2}{*}{ rr } & rr & 19 & $\cdot, \times 1$ & Y),TV & r. & البعدي & \multirow{2}{*}{ الأمان والخصوصية } \\
\hline & $\wedge$ & 1 & $1, \vee \wedge$ & r,or & $\Gamma$. & القبلي & \\
\hline
\end{tabular}




\begin{tabular}{|c|c|c|c|c|c|c|c|}
\hline العظمي & أكبر & دأصغ & المعياري & الحسابي & العدد العد & التطبيقين & المهارة \\
\hline \multirow{2}{*}{$T \varepsilon$} & $r \varepsilon$ & $r_{1}$ & $\cdot, \vee \vee 4$ & rT,TV & r. & البعدي & \multirow{2}{*}{ الصحة والسلامة } \\
\hline & 11 & 1 & $r, 0 \leqslant$ & $\varepsilon, 1$. & $r$. & القبلي & \\
\hline \multirow[b]{2}{*}{$\wedge \wedge$} & $\wedge \wedge$ & 人) & 1,91 & $\wedge \uparrow, \vee$. & $r$. & البعدي & \multirow{2}{*}{ مهارات المواطنة ملاحظة } \\
\hline & Tr & $\varepsilon$ & $7, \cdot 1$ & $10, r T$ & $r$. & القبلي & \\
\hline
\end{tabular}

يتضح من الجدول أعلاه أن متوسط درجات التطبيق البعدي لبطاقة ملاحظة

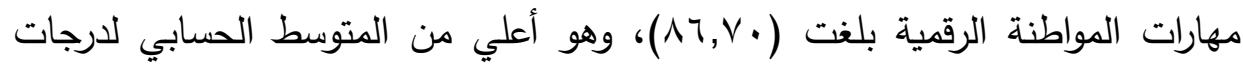
التطبيق القبلي الذي بلغ (r Y, I ) درجة مما يدل علي وجود فرق بين متوسطى درجات التطبيقين علي بطاقة ملاحظة مهارات المواطنة الرقمية لصالح التطبيق البعدي نتيجة تعرضهم للمعالجة التجريبية (الوحدة المقترحة). وبتمثيل درجات مجموعتي البحث باستخدام شكل الأعمدة البيانية اتضح ما يلي:

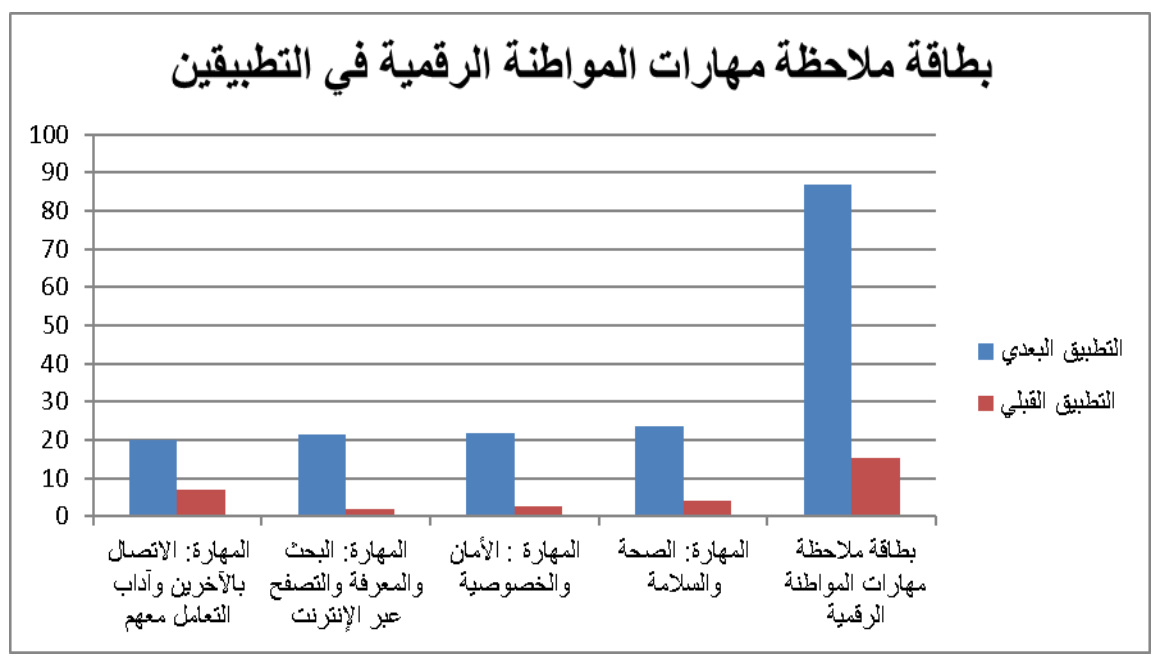

شكل ( r ) ) التمثيل البياني بالأعمدة لمتوسطات درجات التطبيقين

ويتضح من التمثيل البياني السابق وجود فروق واضحة بيانيًا بين درجات التطبيقين علي بطاقة ملاحظة مهارات المواطنة الرقمية. وللتحقق من الدلالة الإحصائية للفرق بين

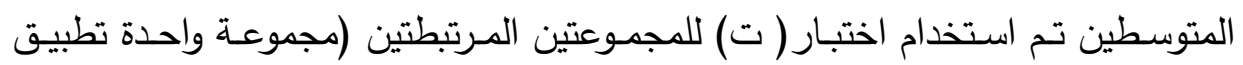




\section{مجلة " دراسات في الطفولة والتربية" - جامعة اسيوط}

متكرر)، وبتطبيق اختبار (ت) لفرق المتوسطين لقياس مقدار دلالة الفرق بين متوسطى درجات التطبيقين اتضح ما يلى: وبطيف احلى

جدول ( r ا ) نتائج اختبار " ت " للفرق بين متوسطي درجات التطبيقين في بطاقة ملاحظة مهارات المواطنة الرقمية

\begin{tabular}{|c|c|c|c|c|c|}
\hline مستوي الدلالة & الدرية & قيمة ت & اللفرعياري & المتوسطين & المهارة \\
\hline مستوي ا.,. & rq & $r \cdot, \wedge$. & $r, \varepsilon r$ & $1 r, .$. & الاتصال بالآخرين وآداب \\
\hline مستوي ا +,. & rq & $\{\wedge, r \uparrow$ & $r, Y \varepsilon$ & $19, Y V$ & البحث والمعرفة والتصفح \\
\hline مستوي ا +., & rq & ov, 17 & $1, \lambda r$ & $19,1 \pi$ & الأمان والخصوصية \\
\hline مستوي 1.,. & rq & $r \wedge, 90$ & $r, v$. & $19,0 \mathrm{~V}$ & الصحة والسلامة \\
\hline مستوي ا.,.• & rq & 7,77 & $7, \leqslant 0$ & $V 1, \varepsilon v$ & بطاقة ملاحظة مهارات \\
\hline
\end{tabular}

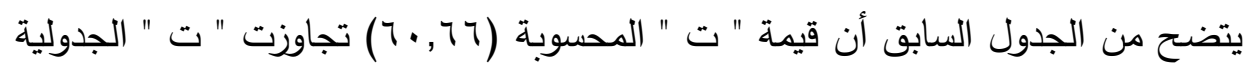
عند درجة حرية (9 ) ) ومستوى دلالة (1 +,. ) مما يدل على وجود فرق حقيقي بين

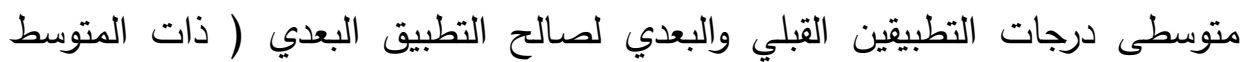
الأكبر ).

وبالتالي تم قبول الفرض الذي ينص على وجود فرق دال إحصائيا عند مستوى الدلالة ( ا ., · ) بين متوسطي درجات التطبيقين القبلي والبعدي لبطاقة ملاحظة مهارات

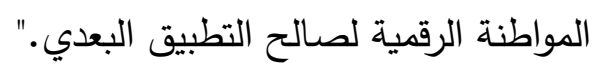
وتتفق النتيجة التي توصلت إليها الدراسة الحالية مع ما توصلت إليه دراسة (حشيش،

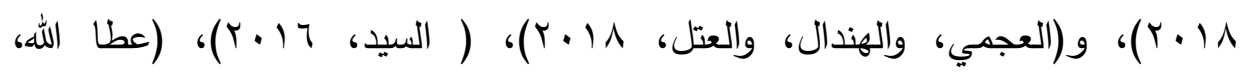
$\cdot(r \cdot r \cdot$

ويمكن إرجاع فاعلية الوحدة المقترحة في تتمية بعض مهارات المواطنة الرقمية

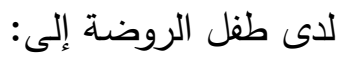


تهيئة البيئة الملائمة لتقديم الأنثطة للأطفال، وتثجيعهم على المشاركة في الأنشطة والتدريب على مهارات المواطنة الرقمية دون خوف أو قلق.

التتويع في الأنشطة ما بين أنشطة قصصية ودرامية وفنية حتى لايشعر الطفل بالملل مثل نثاط (المجتمع الإفتراضي) الذي تتاول مهارة استخدام الأدوات

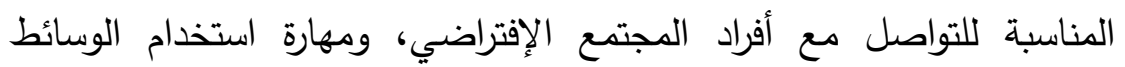

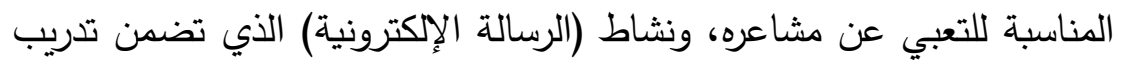
الطفل على عدة مهارات مثل:مهارة تكوين رسالة باستخدام العناصر المعطاة له له

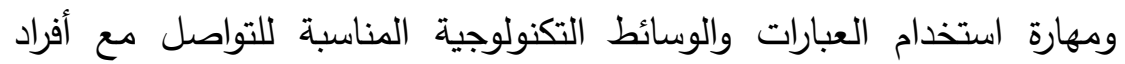
مجتمعه الافتراضي في المناسبات المختلفة ومهارة استخدام عبارات مهذبة عند التواصل مع مجتمعه الافتراضي، ونشاط (احترام الخصوصية) الذي تتاول تدريب الطفل على مهارات مثل: مهارة الاستئذان من الآخرين قبل استخدام

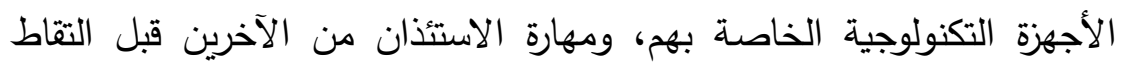

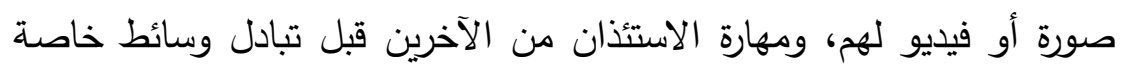

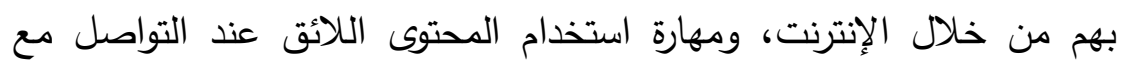

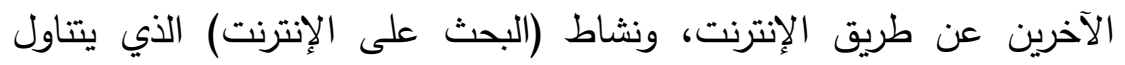

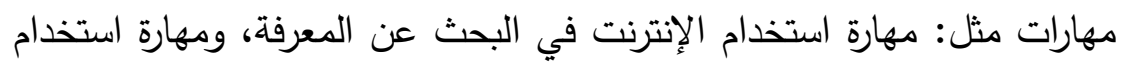
طرق مختلفة للبحث عن المعرفة من خلال الإنترنت مثل البحث الصوتي الصني والبحث بالصور)، ومهارة تحديد الكلمات المفتاحية المناسبة واستخدامها في لإني البحث من خلال الإنترنت. التتوع في استخدام استرتيجيات التعلم النشط أثناء تقديم مهارات المواطنة الرقمية من خلال الوحدة المقترحة مثل: استراتيجية لعب الدور كما في أنشطة (الرسالة

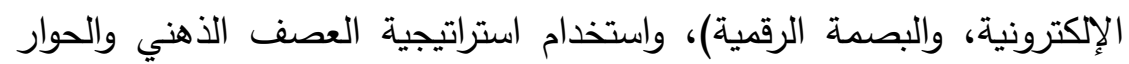
والمناقشة في عدة أنثطة مثل: (برنامج الحماية من الفيروسات، الاستخدام الآمن على الإنترنت)، وكان لهذا التتوع أثر كبير في مشاركة الأطفال الفعالة

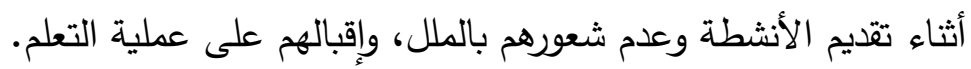




\section{مجلة " دراسات في الطفولة والتربية" - جامعة اسيوط}

\section{اختبار صحة الفرض الثالث :}

" للوحدة المقترحة فاعلية في تتمية بعض مفاهيم ومهارات المواطنة الرقمية لدى

طفل الروضة."

يتضح مما سبق وجود فروق ونتائج ذات دلالة إحصائية بين متوسطي درجات

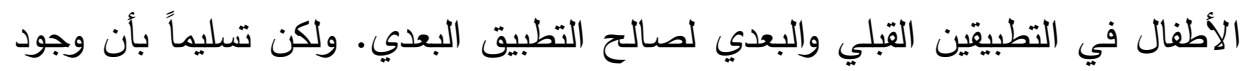

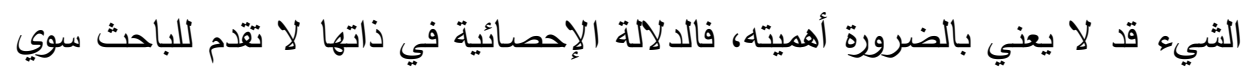

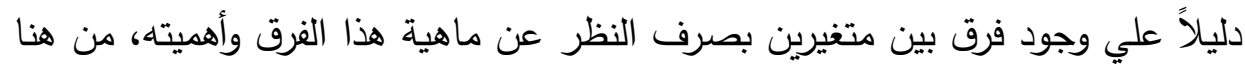
فالدلالة الإحصائية وحدها غير كافية لاختبار فروض البحث فهي شرط ضروري ولكنيه

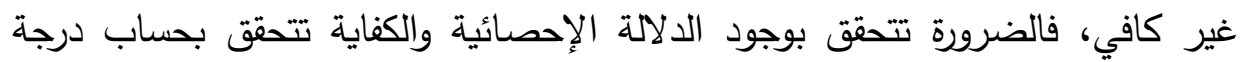

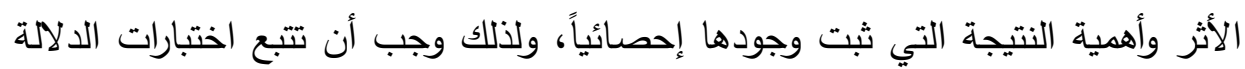
الإحصائية ببعض الإجراءات لفهم معنوية النتائج الدالة إحصائياً وتحديد أهمية النتائج

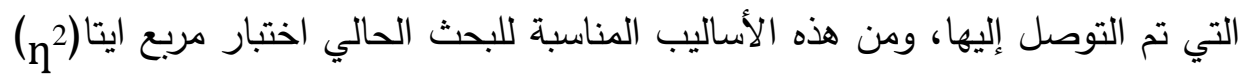
واختبار حجم الأثر (d)، ويهدف اختبار مربع ايتا (n) ) الى تحديد نسبة من تباين المتغير التابع ترجع للمتغير المستقل، كما يوضح الجدول ( \& 1 ) نتائج تطبيق حجم

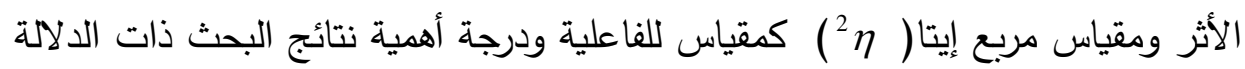
الإحصائية :

جدول ( \& 1 ) نتائج مربع ايتا وحجم الأثر

\begin{tabular}{|c|c|c|c|c|c|c|}
\hline الفاعلية والأثر & $\begin{array}{c}\text { حجم الأثر } \\
\text { (d) }\end{array}$ & $\begin{array}{l}\text { مربع ايتا } \\
\left(\eta^{2}\right)\end{array}$ & الدرية & قيمة ت & المحور & الأداة \\
\hline فعالية مرتفعة وأثر & $\varepsilon, 10$ & $\cdot, \wedge)$ & rq & 11,11 & وآداب التعالمل معهم & \multirow{4}{*}{ المصور } \\
\hline فعالية مرتفعة وأثر & $7, \mathrm{YV}$ & $\cdot, 91$ & rq & 17,11 & والتصفح عبر الإنترنت & \\
\hline فعالية مرتفعة وأثر & $7, r \varepsilon$ & $\cdot, 91$ & rq & $\mid 7,11$ & الأمان والخصوصية & \\
\hline فعالية مرتفعة وأثر & 0,09 & $\cdot, \wedge 9$ & rq & $10, .7$ & الصحة والسلامة & \\
\hline
\end{tabular}


د.// هبة أحمد أحمد البنا فاعلية وحدة مقترحة لتنمية بعض مفاهيم ومهارات المواطنة الرقمية لاى طقلة بعل الروضة مفيمة

\begin{tabular}{|c|c|c|c|c|c|c|}
\hline الفاعلية والأثر & $\begin{array}{c}\text { حجم الأثر } \\
\text { (d) }\end{array}$ & $\begin{array}{l}\text { مربع ايتا } \\
\left(\eta^{2}\right)\end{array}$ & الحربة & قيمة ت & المحور & الأداة \\
\hline فعالية مرتفعة وأثر & $V, I V$ & •, 94 & rq & $|9, \Gamma|$ & الاختبار ككل & \\
\hline فعالية مرتفعة وأثر & $V, V Y$ & $\cdot, 9 \leqslant$ & rq & $r \cdot, \Lambda$. & وآداب التصال بالآخرين معهم & \multirow{5}{*}{ بطاقة } \\
\hline فعالية مرتفعة وأثر & 18,97 & $\cdot, 99$ & rq & $\sum \Lambda, Y^{\prime}$ & والتصفح عبر الإنترنت والمعرفة & \\
\hline فعالية مرتفعة وأثر & $r,, r r$ & $\cdot, 99$ & rq & OV, 1T & الأمان والخصوصية & \\
\hline فعالية مرتفعة وأثر & $1 \cdot, \times 0$ & $\cdot, 9 \vee$ & rq & $r \wedge, 90$ & الصحة والسلامة & \\
\hline فعالية مرتفعة وأثر & rT,OT & $\cdot, 99$ & rq & $7 \cdot 77$ & البطاقة ككل & \\
\hline
\end{tabular}

\section{يتضح من الجدول ( 1 ( ) ما يأتي:}

- بالنسبة للاختبار المصسور ككل بلغت قيمـة اختبار مربع إيتا(

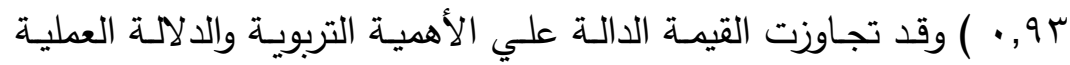

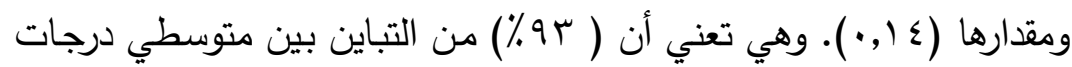

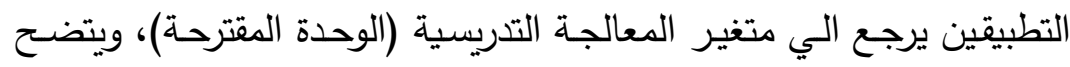

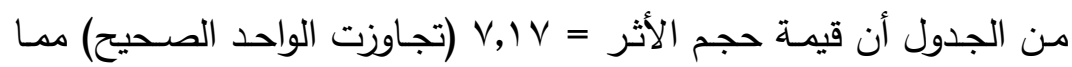

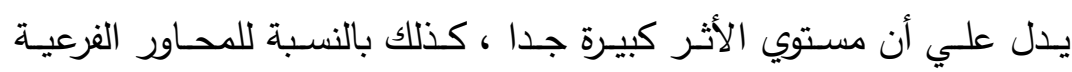
للاختبار .

- - بالنسبة لبطاقـة الملاحظـة ككل بلغت قيمـة اختبـار مربع إيتـا(

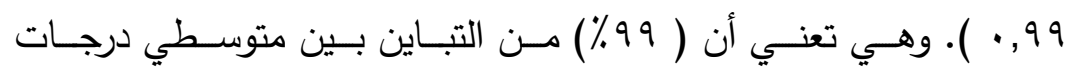

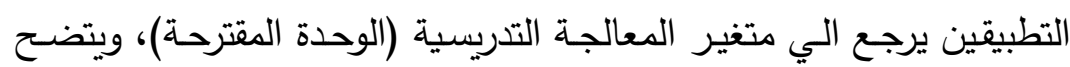

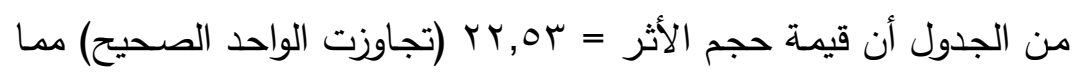




\section{مجلة " دراسات في الطفولة والتربية" - جامعة اسيوط}

يـل علـي أن مسـتوي الأثر كبيـرة جدا ، كذلك بالنسبة للمهارات الفرعيـة لبطاقة الملاحظة.

- - مبذلك يمكن القول أن هناك أثر كبير وفاعلية مرتفعة للوحدة المقترحة في تتمية مفاهيم ومهارات المواطنة الرقمية لدي طفل الروضة.

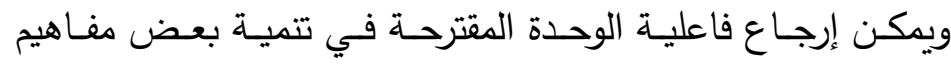

$$
\text { ومهارات المواطنة الرقمية لدى طفل الروضة إلى اعلى: }
$$

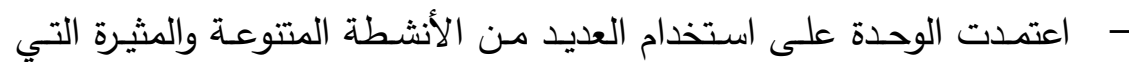

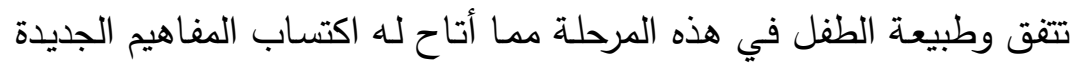

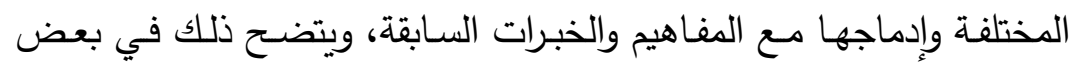

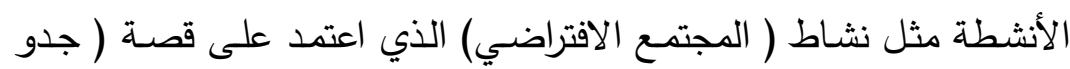

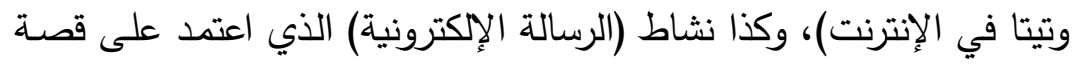

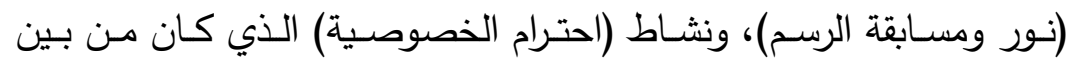
عناصره قصـة (مقالب نـادر)، وكان لاستخدام هذه القصص أثر كبير في لوني

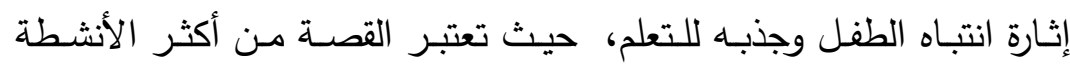
المحببة لنفس الطفل. - - التتوع في الأنثطة المقدمة ما بين أنشطة قصصية ودرامية وفنية مما ساهم في مواجهة الفروق الفردية بين الأطفال. - - استخدام استراتيجيات تدريسية مختلفة كالحوار والمناقثة، والعصف الذهني، الذهني، والتعلم بالإكتثاف ولعب الدور، وحل المشكلات مما أتاح للطفل القيام بدور إيجابي في عملية التعلم وعدم الاعتماد على الأساليب التقليدية في التدريس التي تعتمد على التلقين والحفظ وتجعل الطفل متلقي سلبي وهذا بدوره يقلل

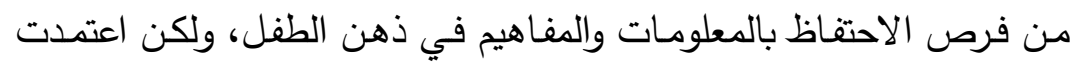
الدراسة الحالية على استراتيجيات التعلم النشط. - - التدرج في تقديم الدفاهيم للطفل من السهل إلى الصعب ومن البسيط إلى المركب ومن المحسوس للمجرد، وكذا استخدام المفاهيم القريبة من خبرات 
الطفل ومهاراته الحياتية، وارتباط هذه المفاهيم والمهارات بالمواقف الحياتية

$$
\text { التي يعيشها الطفل. }
$$

- - استخدام بعض الوسائل التكنولوجية والإنترنت أثناء تقديم العديد من الأنثطة

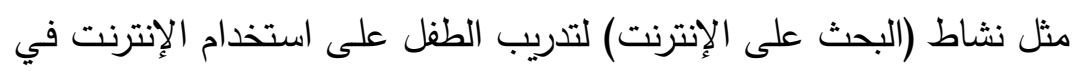

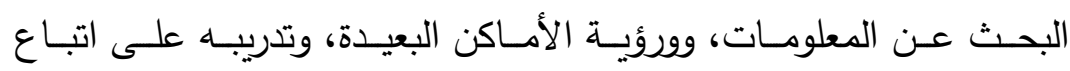

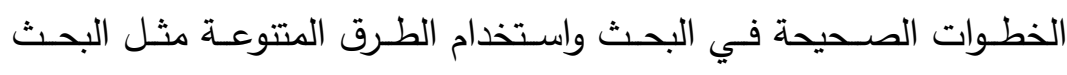

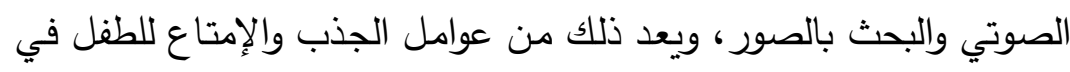
هذا العصر ، مما ساعد على انجذاب الطفل ومشاركته الفعالة في الأنثطة. - - التدرج في تقديم النشاط من خلال البدء بالتهيئة والإثارة لتحفيز الطفل وتهيئته

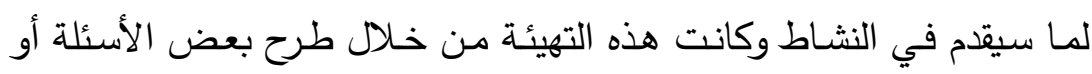

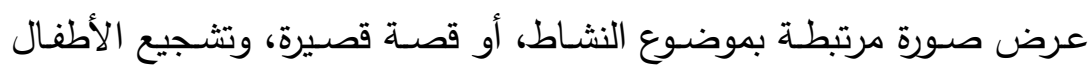

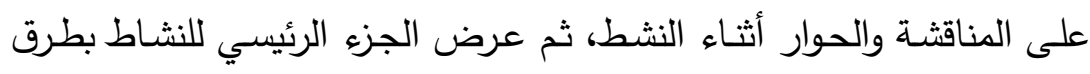

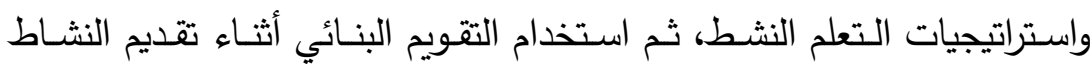
واستخدام أوراق العمل المختلفة التي تساهم في تأكيد المفهوم لدى الطفل. اختبار صحة الفرض الرابع:

"توجد علاقة ارتباطية ذات دلالة احصائية بين درجات اختبار مفاهيم المواطنة

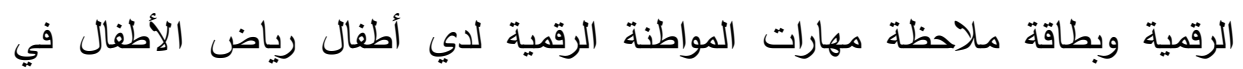

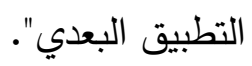

لاختبار صحة هذا الفرض قامت الباحثة بدراسة مصفوفة معاملات ارتباط بيرسون بين أبعاد متغيري البحث (بطاقة ملاحظة مهارات المواطنة الرقمية، اختبار

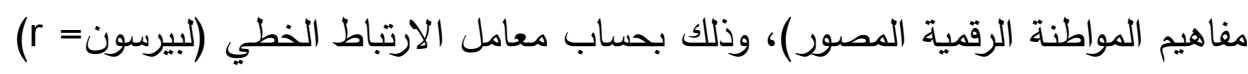

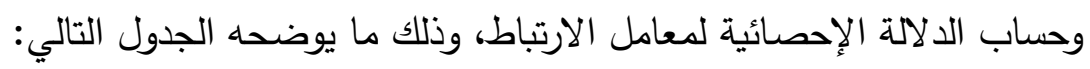




$$
\text { مجلة " دراسات في الطفولة والتربية" - جامعة اسيوط }
$$

\begin{tabular}{|c|c|c|c|c|}
\hline الأهمية التربوية & $\begin{array}{c}\text { معامل التحديد } \\
r^{2}\end{array}$ & الاحصائية & معامل الارتباط & المتغيرين \\
\hline ذات علاقة طردية تربية & •, or & دالة عند مستوي & . VYT & الاختبار المصور - بطاقة \\
\hline
\end{tabular}

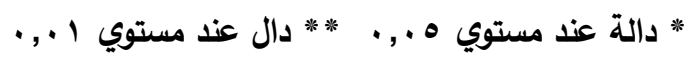

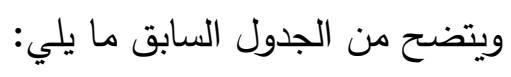

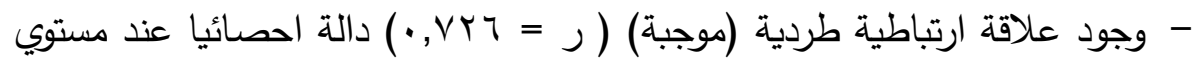
1. , • بين درجات الأطفال في بطاقة ملاحظة مهارات المواطنة الرقمية ودرجاتهم

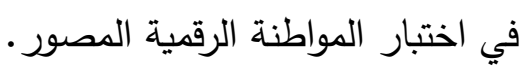
- للتعرف علي فاعلية العلاقة ودلالتها العملية تم حساب معامل التحديد به به • وهو ما يعني أن ro\% من التباين في درجات بطاقة ملاحظة مهارات المواطنة

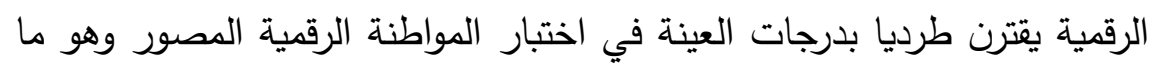
يعني الأهمية التربوية القوية للعلاقة بين المتغيرين. - - وفي ضوء ذلك يتم قبول الفرض الذي يعني وجود علاقة ارتباطية طردية ذات دلالة احصائية بين درجات الأطفال علي بطاقة ملاحظة مهارات المواطنة

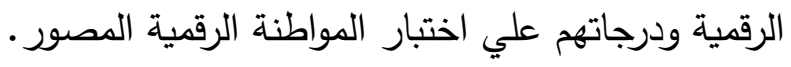

\section{توصيات الدراسة}

في ضوء ما أسفرت عنة الدراسة من نتائج توصي الباحثة بالآتي: 1. ضرورة تدريب معلمات رياض الأطفال على تتمية مفاهيم ومهارات المواطنة الرقمية. r. تضمين أنثطة في مناهج رياض الأطفال لتتمية مفاهيم ومهارات المواطنة الرقمية. r. تضمين مفاهيم ومهارات المواطنة الرقمية في مناهج رياض الأطفال. 
ع. تدريب الطالبة المعلمة على استخدام استراتيجات التعلم النشطة التي تساهم في تتمية مفاهيم ومهارات المواطنة الرقمية لدى طفل الروضة.

\section{بحوث ودراسات مقترحة}

تقترح الباحثة إجراء البحوث والدراسات الآتية:

ا. فاعلية وحدة مقترحة في المواطنة الرقمية لتنمية مفاهيم ومهارات المواطنة الرقمية

لاى تلاميذ المرحلة الابتدائية.

r. فاعلية برنامج تدريبي لمعلمات رياض الأطفال على تدريس مفاهيم ومهارات المواطنة الرقمية لطفل الروضة. 


\section{مجلة " دراسات في الطفولة والتربية" - جامعة اسيوط}

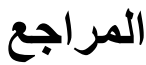

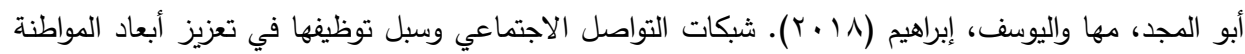

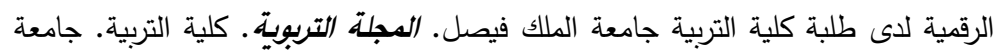

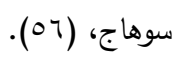

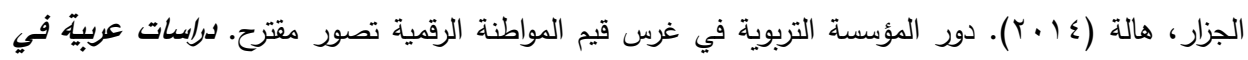

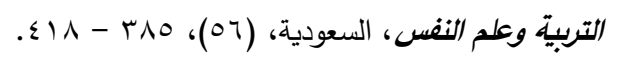

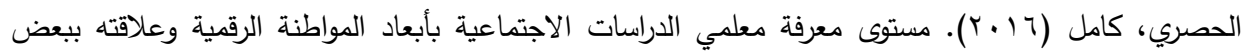

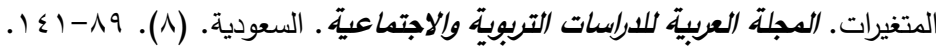

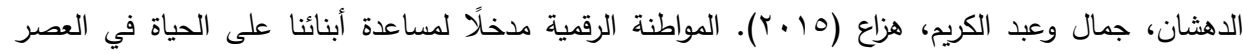

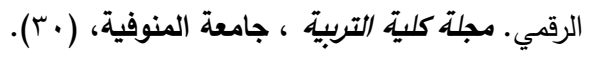

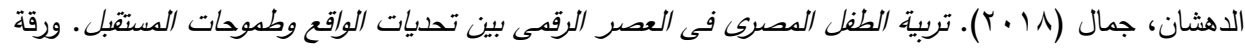

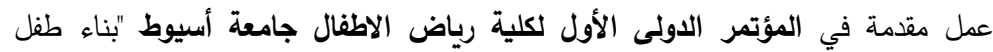

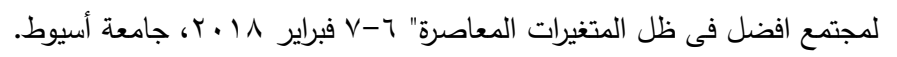

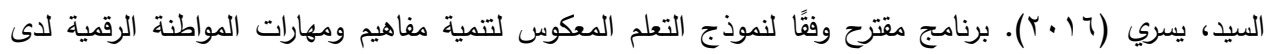

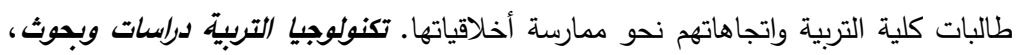

$$
\text { مصر، (Yq) (Y)، }
$$

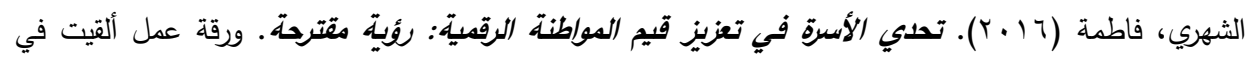

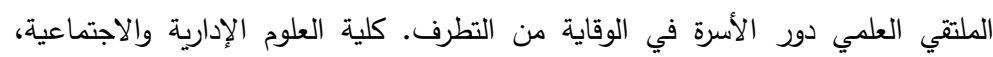

$$
\text { جامعة نايف العربية للعلوم الأمنية، السعودية. }
$$

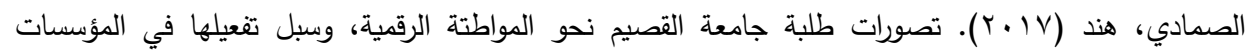

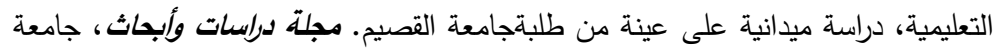

$$
\text { الجلفة، الجزائر • (rV) - (rV). }
$$

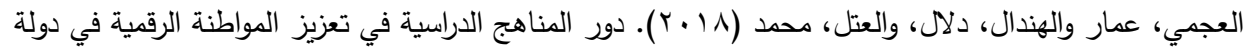

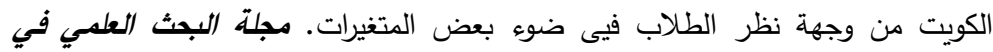

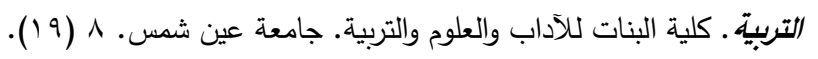

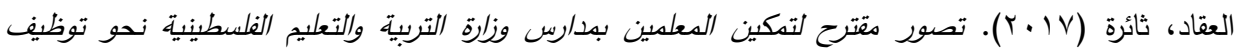

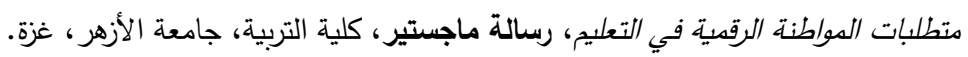

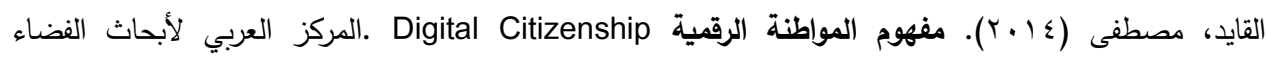

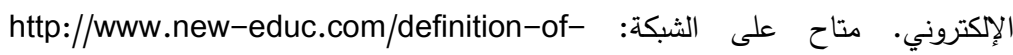

digital-citizenship\#.U_pGj_QW2So

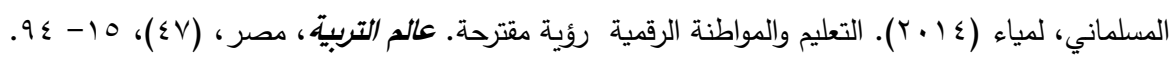

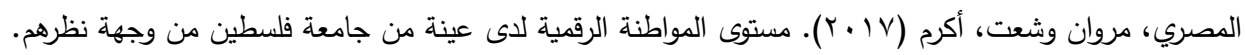

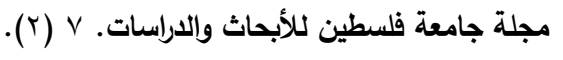




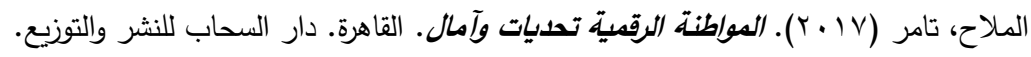

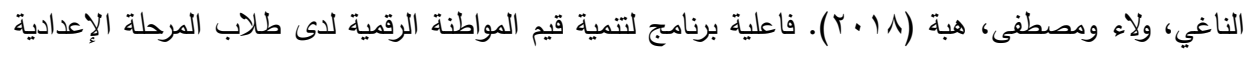

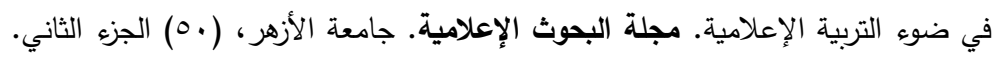

$$
.7 \leqslant r-7 . r
$$

بشير، جيدور (17 (Y). أثر الثورة الرقمية والاستخدام المكثف لشبكات التواصل الاجتماعي في رسم الصورة

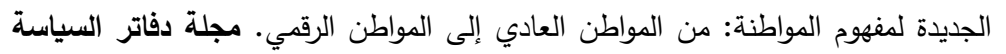

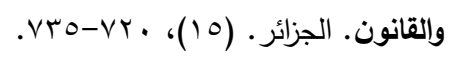

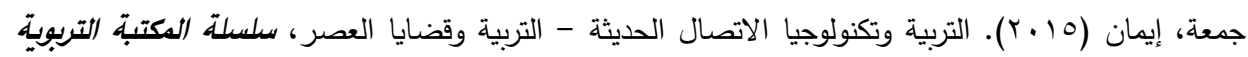

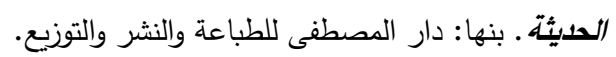

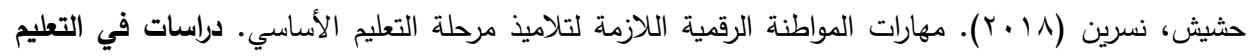

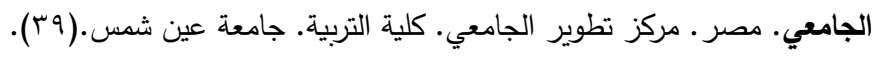

زاهر، ضياء الدين (ع . ب). التكنولوجيا الرقمية ودورها في تجديد النظم التعليمية. مستقبل التربية العربية. القاهرة.

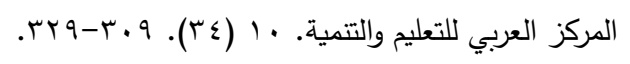

شرف، صبحي والدمرداش، محمد (ع ( ب). معايير التربية على الدواطنة الرقمية وتطبيقاتها في الدناهج الدراسية.

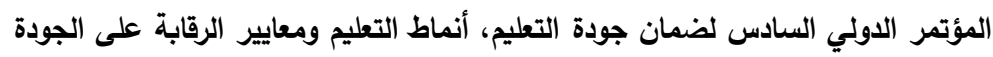

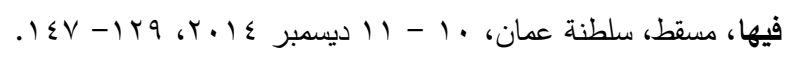

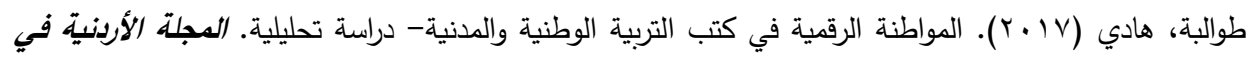

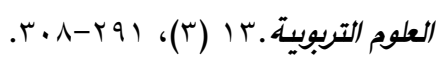

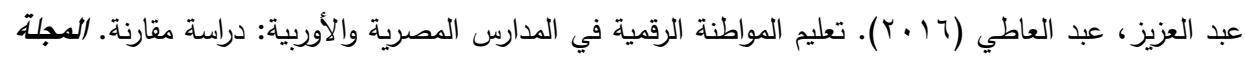

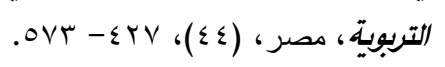

عبد الفتاح، أمل (Y V P). دور مؤسسات التتشئة الاجتماعية في نشر قيم المواطنة الرقمية لتحقيق التتمية المستدامة.

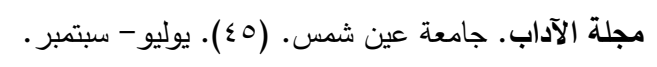

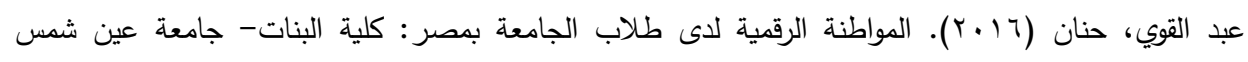

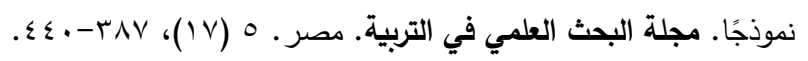

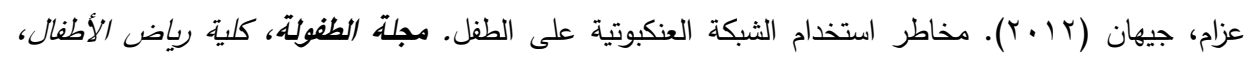

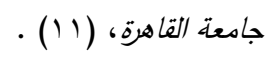

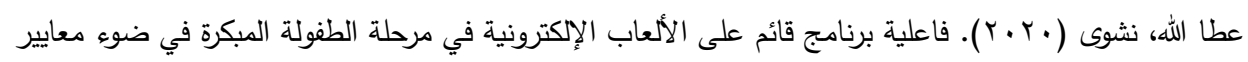

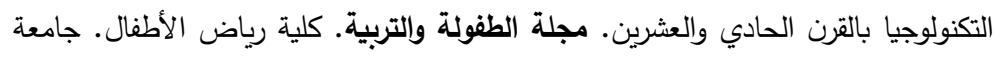

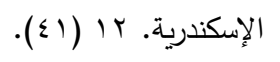

كفافي، حنان (17 (Y). تصور مقترح لتتمية وعي تلاميذ مرحلة التعليم الأساسي بثقافة المواطنة الرقمية. دراسات

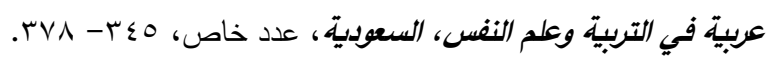

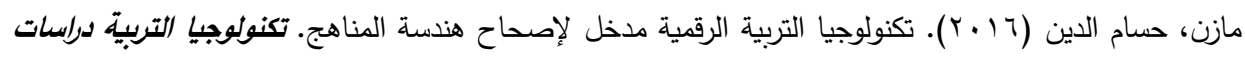

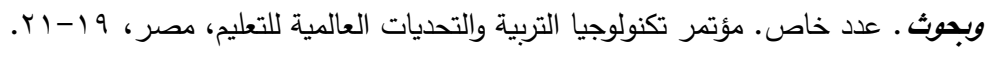




\section{مجلة " دراسات في الطفولة والتربية" - جامعة اسيوط}

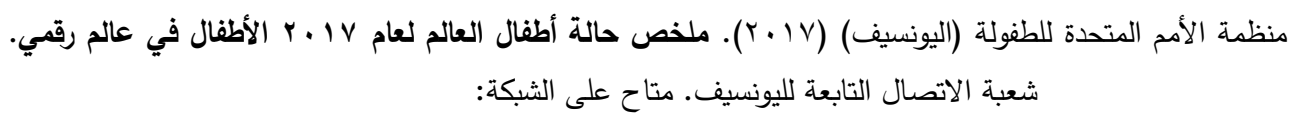
.unicef.org/publications/files/SOWC_2017_Summary_Ar_Web.pdfhttps://www

$$
\begin{aligned}
& \text { تم استرجاعه بتاريخه } 1 \text { يناير ·.r.r. }
\end{aligned}
$$

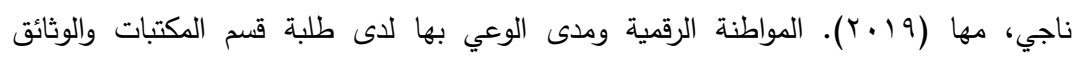

$$
\begin{aligned}
& \text { والمعلومات بجامعة أسيوط: دراسة استكثافية. المجلة العلمية للمكتبات والوثائق والمعلومات. ـ (r). } \\
& \text { ثانيًا: المراجع الأجنبية }
\end{aligned}
$$

Alberta Education (2012). Digital Citizenship Policy Developmeny Gide. Alberta.

Couros, A.,\& Hildebrandt. K (2015). Digital Citizenship Education in Saskatchewan Schools. Apolicy Planning Gide for school divisions and schools to implement digital citizenship education from kindergarten to grade 12. Saskatchewan Ministry of Education.

Decarlo, M. J.; Lee, V. J.; Grant, A., \& Neuman, D. (2017). Information and Digital Literacies in a Kindergarten Classroom: An I-LEARN Case Study. Early Childhood Education Journal. Springer Science.265-275

Farmer, L. (2011). Teaching Digital Citizenship. World Library and Information Congress. th 77 IFLA General Conference and Assembly. 13-18 August 2011, San Juan, Puerto Rico.

Gazi, Zehra. (2016). Internalization of Digital Citizenship for the Future of All Levels of Education. Education and Science. 41 (186). 137-148.

Isman, A.,\& Gungoren.O.C (2013). Being Digital Citizen,The International Conference On New Horizons In Education. Procedia Social and Behavioral Science.

Lenhart, A.; Purcell, K.; Smith, A.,\& Zickuhr,K. (2010). Social Media \& Mobile Internet Use Among Teens and Young Adults.U.S.A, Pew Research Center.

Ribble, M. (2015). Digital Citizenship In Schools Nine elements all students should know (3 rd ed). U.S.A. International Society for Technology In Education.

Ribble, M. (2012). Digital Citizenship For Educational Change. Kappa Delt Pi Record. 48 (4). 148-151.

Ribble, M., \& Baily, G. (2007). Digital Citizenship In Schools. U.S.A. International Society for Technology In Education.

Ribble, M., \& Bailey, G. (2006). Digital Citizenship at all grades levels. International Society for Technology and Education. Information Literacy: Available at: www.iste.org. Retrieved on 1 August 2018.

Ribble, M.; Baily,G., \& Ross, T. (2004). Digital citizenship Addressing Appropriate Technology Behaviour. U.S.A. Canada. International Society for Technology In Education.

Quan-Hasse, A., \& Wellman, B. (2004). How does the internet affect social capital. In M. Huysman\& V. Wulf (EDS), Social capital and information techonology. 113-136. Cambridge: The MIT Press.

Winther, D. (2017). How does the time children spend using digital technology impact their mental wel-being, social relationship and physical activity?. The Unicef Office Of Research - Innocenti.

Hollandsworth, R.; Donovan, J.,\& Welch, M (2017). Digital Citizenship:You can not go home again. TechTrends Journal, 6.

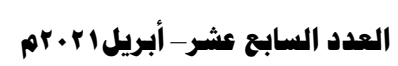

